\title{
Political-Security Risk in the Oil and Gas Industry: The Impact of Terrorism on Risk Management and Mitigation
}

\author{
by \\ Lars Borge Blomquist \\ Thesis presented in fulfilment of the requirements for the degree \\ of master of Arts (International Studies) in the Faculty of Arts and \\ Social Science at Stellenbosch University
}

Supervisor: Dr Derica Lambrechts

March 2015 


\section{Declaration}

By submitting this thesis, I declare that the entirety of the work therein is my own, original work, that I am the sole author thereof (save to the extent explicitly otherwise stated), that reproduction and publication thereof by Stellenbosch University will not infringe any third party rights and that I have not previously in its entirety or in part submitted it for obtaining any qualification.

Date: 01 November 2014

Copyright (C) 2010 Stellenbosch University

All rights reserved. 


\section{Abstract}

International oil and gas companies are experiencing an increase in terrorist attacks. After the oil and gas industry became a legitimate target for terrorist groups in the 1990s the number of attacks have increased yearly, with a spike after the 9/11 attacks. In today's interconnected world political risk is not only about the relationship between the host government and the company. Oil and gas companies may experience risks on a transnational, national and human security level. Because of this, the success of new investments often depends on the successful utilization of risk management strategies. This research study focuses on the importance of political-security risk in the oil and gas industry. This is a risk-management tool to be used before and during international operations; it enables companies to be better prepared to deal with risks that may arise. In January 2013 the oil and gas industry experienced one of its deadliest attacks. The In Amenas gas facility in Algeria was attack by terrorists and in a four-day siege 40 people lost their lives. This forced the oil and gas industry to reconsider its focus on security management. As one of the contractors at the facility, Statoil undertook a thorough analysis of security at the site as well as of the company's corporate security risk management. The report revealed a lack of focus on political-security risk. Accordingly, the main research question in this study concerns the effect of terrorism on politicalsecurity risk in the oil and gas industry; it specifically analyzes the In Amenas attack. The aim of this study is to answer this question along with two sub-questions, which complement and support the main research question. The first sub-question concerns the factors that contributed to the attack in In Amenas: why was risk mitigation not successful? The second sub-question looks at the possibilities for international oil and gas companies to mitigate the risk of terrorism; or is this a risk that can only be managed? This study argues that political-security risk has not been used to its full potential in the oil and gas industry. The oil and gas industry has always focused on site security, but a broader more holistic approach to risk management has been lacking. However, as a result of the In Amenas incident, the industry has become more willing to have a new discussion on security and this has resulted in small changes in the way companies operate. 


\section{Opsomming}

Internasionale olie- en gasmaatskappye ondervind ' $n$ toename in terreur aanvalle. Nadat die olie en gasindustrie ' $n$ wettige teiken vir tereurgroepe in die 1990s geword het, het die aantal aanvalle per jaar toegeneem, met 'n skerp styging na die 9/11 aanvalle. In vandag se onderling verbonde wêreld hou die politiese risiko nie net verband met die verhouding tussen die gasregering en die maatskappy nie. Olie- en gasmaatskappye mag risiko's op trans-nasionale, nasionale en menslike sekuriteitsvlak ervaar. As gevolg hiervan maak die sukses van nuwe beleggings dikwels staat op die suksesvolle gebruik van risiko-bestuur strategieë. Hierdie navorsingstudie fokus op die belang van ' $n$ politiese veiligheidsrisiko in die olie en gasindustrie. Hierdie is ' $n$ risiko-bestuur gereedskap wat gebruik sal word voor en tydens internasionale operasies; dit stel die maatskappye in staat om beter voorbereid te wees om die risiko's wat mag voorkom te hanteer. In Januarie 2013 het die olie en gasindustrie een van die dodelikste aanvalle beleef. Die In Amenas olie-aanleg in Algerië is deur terroriste aangeval en tydens ' $n$ dae lange inval het 40 mense hul lewens verloor. Dit het die olie en gasindustrie gedwing om hul fokus op veiligheidsbestuur te heroorweeg. As een van die kontrakteur by die aanleg het Statoil ' $n$ deeglike ontleding van die sekuriteit by die plek sowel as die maatskappy se korporatiewe veiligheid risikobestuur onderneem. Die verslag het ' $n$ gebrek aan fokus op die politiese veiligheidsrisiko getoon. Die hoof navorsingsvraag in hierdie studie het betrekking op die effek van terreur op politiese veiligheidsrisiko in die olie- en gasindustrie; dit ontleed spesifiek die In Amenas aanval. Die doel van hierdie studie is om hierdie vraag tesame met twee sub-vrae wat die hoof navorsingsvraag komplimenteer en ondersteun. Die eerste sub-vraag het betrekking op die faktore wat bygedra het tot die aanval in In Amenas: hoekom was risiko mitigasie onsuksesvol? Die tweede sub-vraag kyk na die moontlikhede vir internasionale olie- en gasmaatskappye om die risiko van terreur te versag; of is hierdie ' $n$ risiko wat slegs bestuur kan word? Hierdie studie argumeneer dat politiese veiligheidsrisiko nie tot sy volle potensiaal in die olie en gasindustrie gebruik is nie. Die olie en gasindustrie het altyd gefokus op die veiligheid van die plek, maar ' $n$ breër holistiese benadering tot risiko-bestuur het ontbreek. As gevolg van die In Amenas insident, het die industrie meer gewillig geword om ' $n$ nuwe bespreking oor veiligheid te hê en dit het klein veranderinge in die manier waarop maatskappye opereer tot gevolg gehad. 


\section{Acknowledgments}

First, I would like to thank my supervisor, Dr. Derica Lambrechts for her valuable advices, encouragement and comments throughout this process. Without her deadlines, guidance and support I would not have been able to complete this thesis.

I would like to thank my editor, Dr. Rob Gaylard, for his outstanding work. I would also express my gratitude to Carien Steel for translating the abstract to Afrikaans. 


\section{Contents}

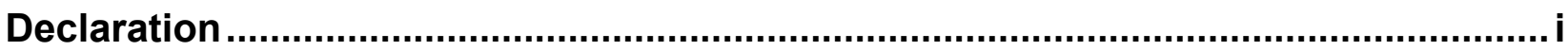

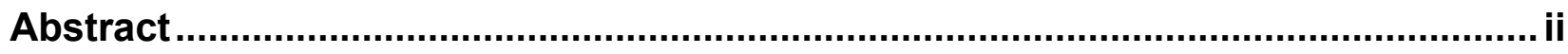

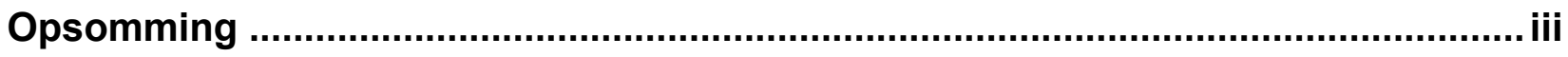

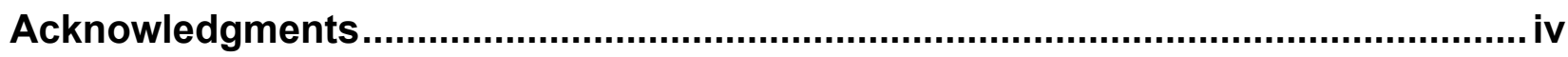

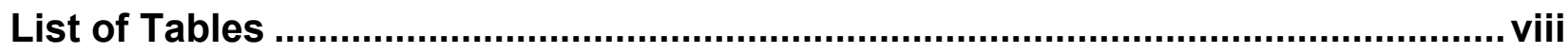

List of Maps .......................................................................................................... ix

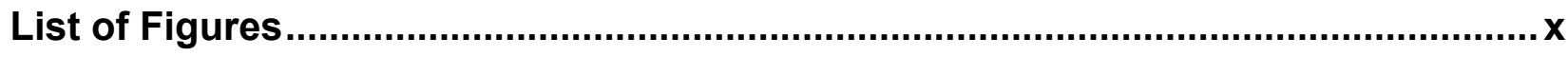

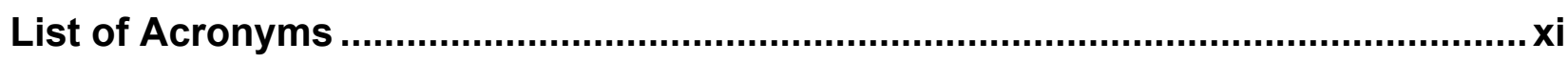

Chapter One: Introduction ...............................................................................

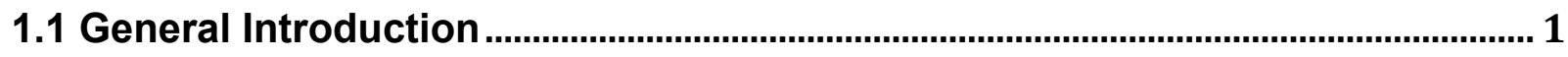

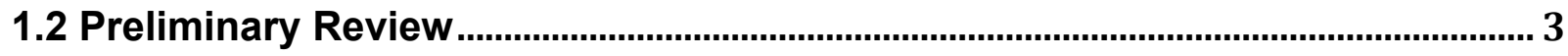

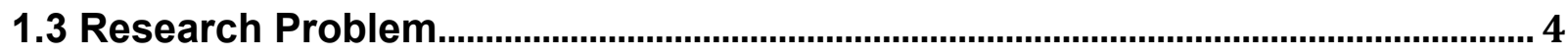

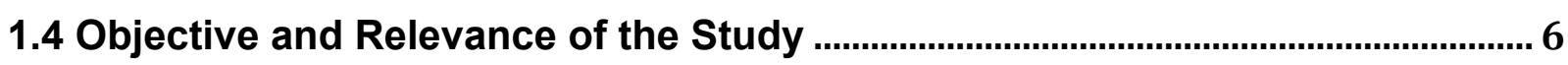

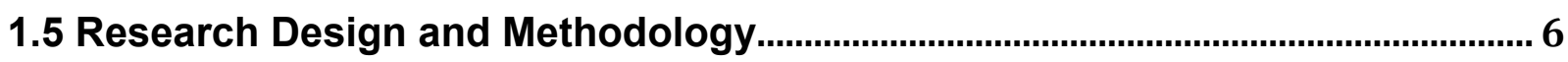

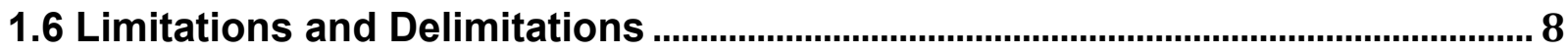

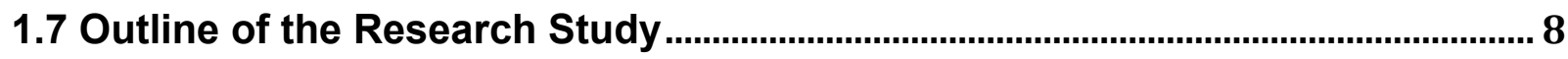

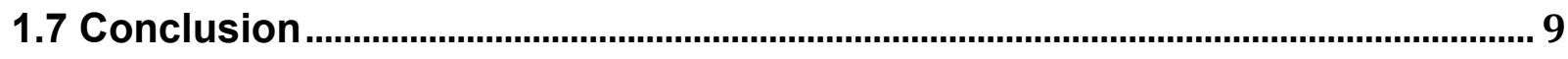

Chapter Two: Theoretical Perspectives and Conceptualization.............................11

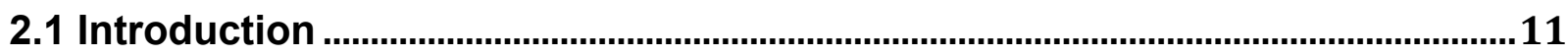

2.2 Theoretical Grounding: Rational Choice Theory and Problem-Solving and

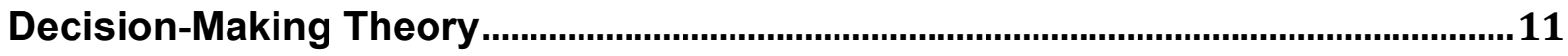

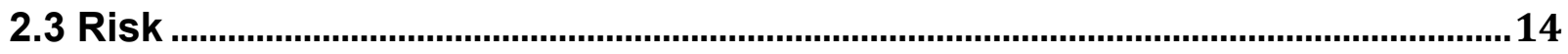

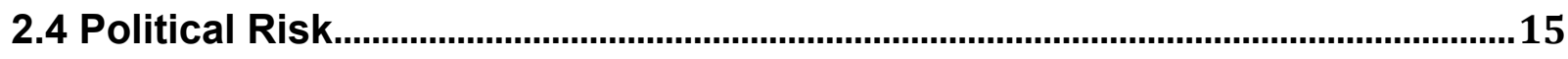

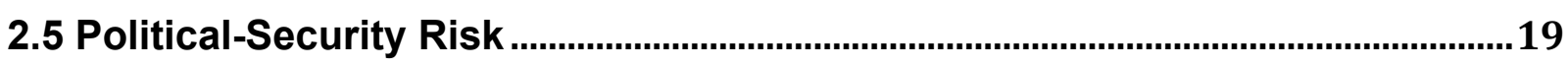

2.6 Macro and Micro Political Risk ..........................................................................21

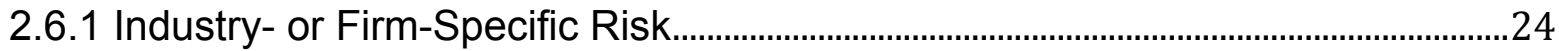

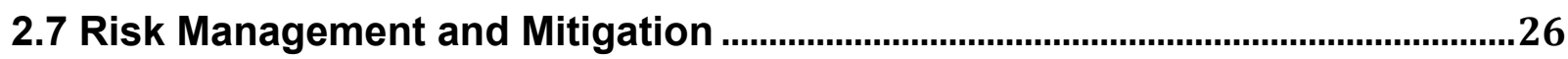

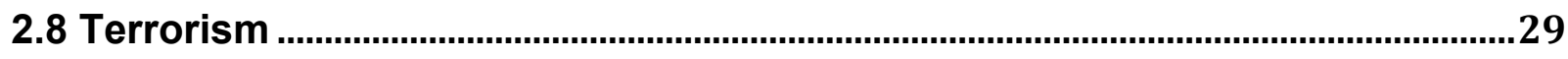

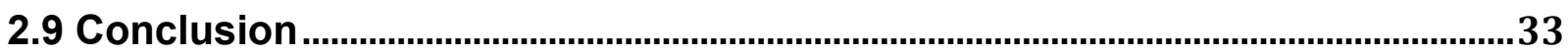


Chapter Three: Terrorism in Northern Africa, with Focus on the Oil and Gas

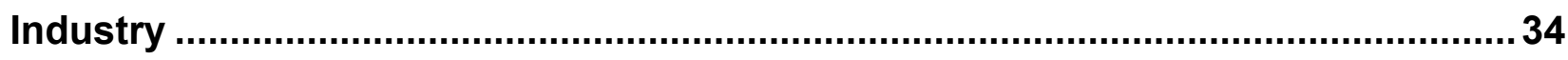

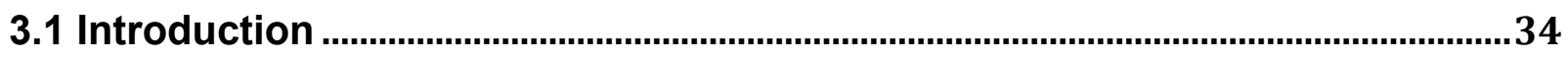

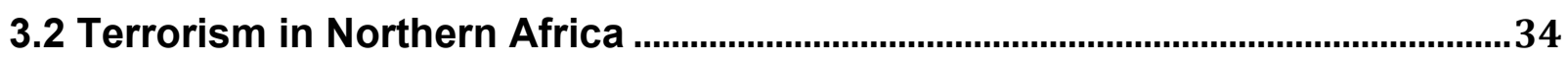

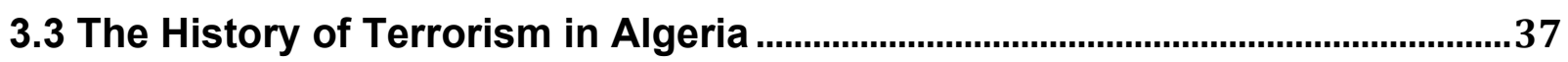

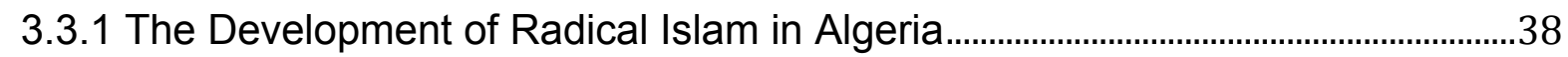

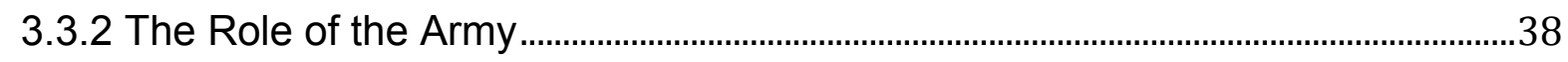

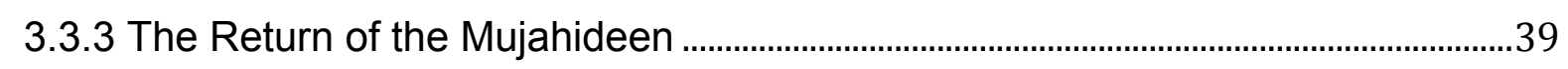

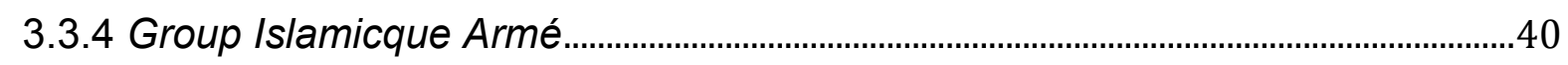

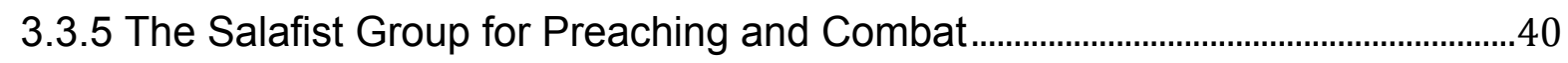

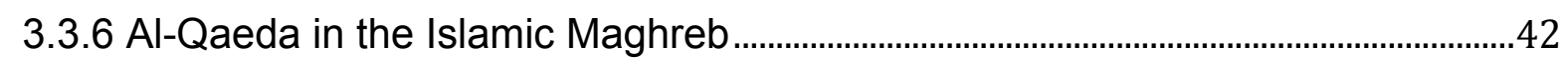

3.3.7 Mokhtar Belmokhtar and the Lead-up to the In Amenas Attack ............................43

3.4 Terrorism in the Oil and Gas industry .................................................................44

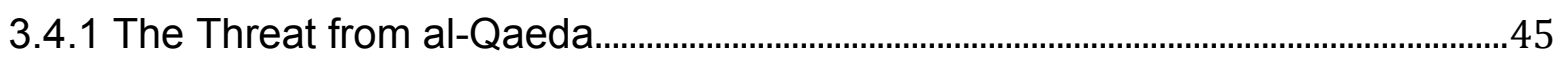

3.4.2 9/11 and the New Focus on the Oil and Gas Industry ............................................46

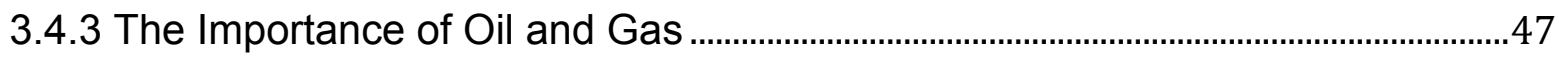

3.4.4 Terrorist Should only Attack Targets where the Benefit Outweighs the Cost..47

3.4.5 How Terrorism is Affecting the Oil and Gas Industry Around the World ...........48

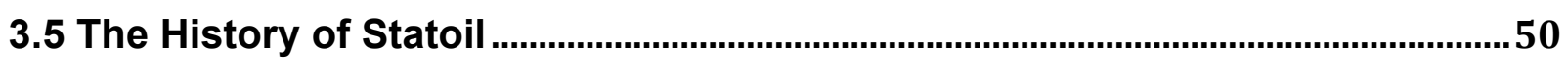

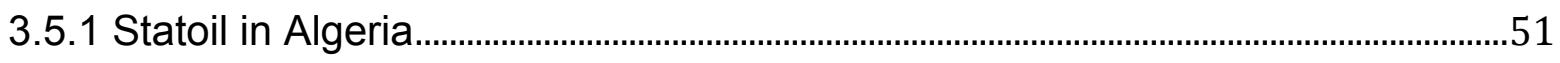

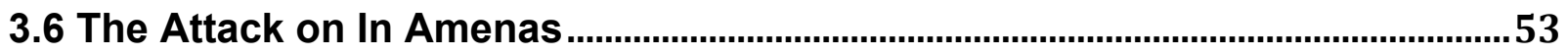

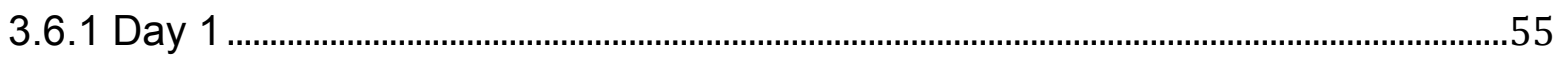

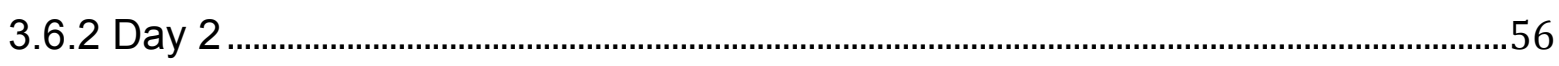

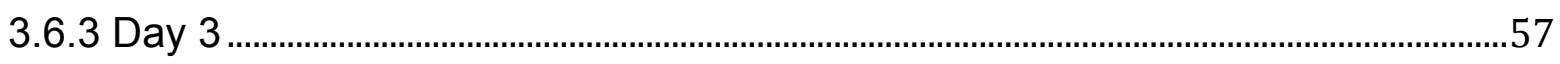

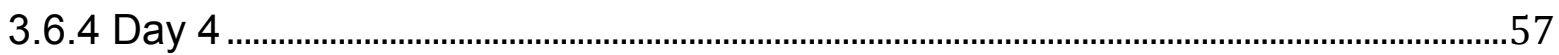

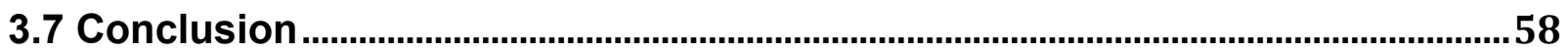

Chapter Four: The Effect of Terrorism on Political-Security Risk in the Oil and Gas

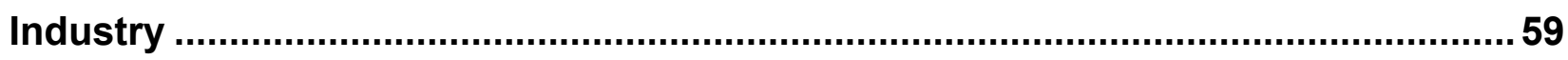

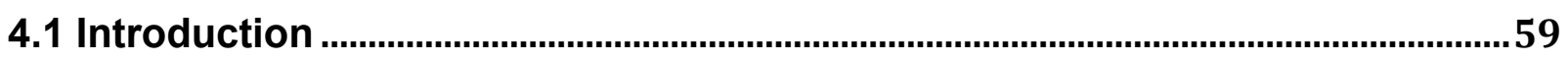

4.2 The Security Situation at the In Amenas Facility Before the Attack .................60

4.2.1 The In Amenas Security System: Government and Corporate Responsibility.

4.2.2 The Security Risk-Management Process Before the Attack .................................62 


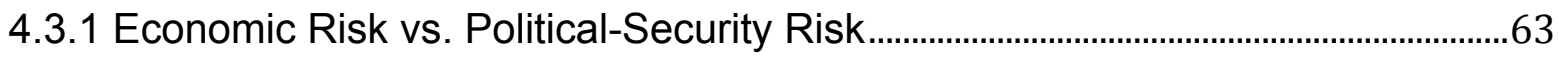

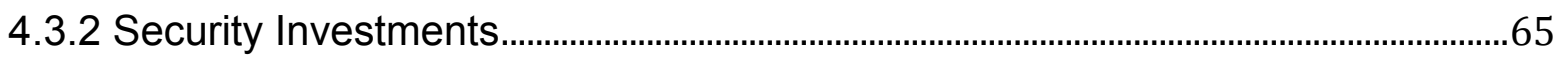

4.3.3 Regional Situational Awareness ..................................................................................66

4.3.4 Political-Security Risk Management and the Lack of Integration...........................68

4.3.5 BP and the Use of Political-Security Risk ….............................................................

4.4 Changes in the Oil and Gas Industry After the In Amenas Incident ........................72

4.5 Factors Contributing to the Attack in In Amenas and the Unsuccessful Risk Mitigation ...................................................................................................................74

4.6 The Management of Terrorism and Complications with Mitigation.................77

4.7 Risk Management Recommendations for the Oil and Gas Industry.................79

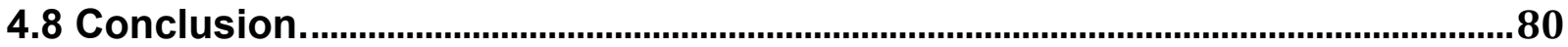

Chapter Five: Conclusion and Evaluation of the Research Study ........................ 82

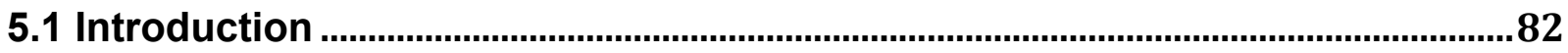

5.2 Progress of the Research Study

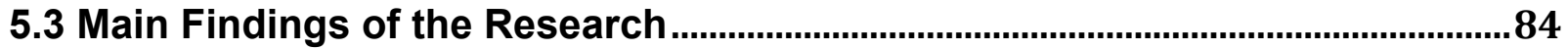

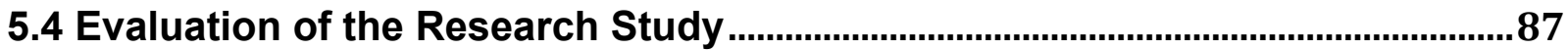

5.5 Recommendations for Further Research .............................................................88

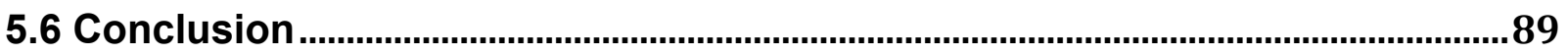

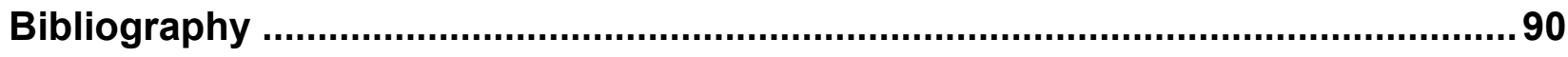

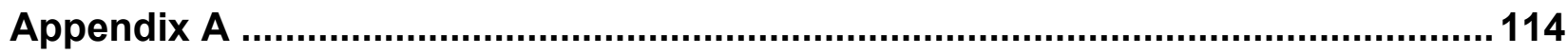

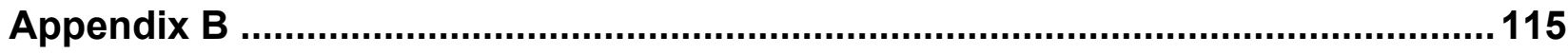




\section{List of Tables}

Table 3.1: Distribution of gas reserves 2013

Table 3.2: Distribution of oil reserves 2013

Table 4.1: Main findings in the In Amenas report $\quad 75$

Table 4.2: New security measures $\quad 77$ 


\section{List of Maps}

Map 3.1: Overview of the Maghreb region 35

Map 3.2: Algeria's main gas fields 52

Map 3.3: In Amenas site overview 54

Map 3.4: Overview of the production area 56 


\section{List of Figures}

Figure 4.1: Illustrative overview of the reporting lines in Statoil 


\section{List of Acronyms}

$\begin{array}{ll}\text { AQIM } & \text { Al Qaeda in Islamic Maghreb } \\ \text { BP } & \text { British Petroleum } \\ \text { DPI } & \text { Development and Production International } \\ \text { EIAD } & \text { Energy Infrastructure Attack Database } \\ \text { ETA } & \text { Euskadita Askatasuna } \\ \text { FARC } & \text { Fuerzas Armadas Revolucionaria de Colombia } \\ \text { FIS } & \text { Front Islamique du Salut } \\ \text { FLQ } & \text { Front de Liberation du Quebec } \\ \text { FLN } & \text { Front de Libération Nationale } \\ \text { GIA } & \text { Group Islamicque Armé } \\ \text { GSPC } & \text { Group Salafiste pour la Prédication et le Combat } \\ \text { HSE } & \text { Health, Safety and Environment } \\ \text { IMF } & \text { International Monetary Found } \\ \text { IERATE } & \text { The International Terrorism: Attributes of Terrorist Events } \\ \text { MENA } & \text { Middle East and Northern Africa } \\ \text { MEND } & \text { Movement for Emancipation of the Niger Delta } \\ \text { MUJAO } & \text { Movement for Oneness and Jihad in Western Africa } \\ \text { OPIC } & \text { Overseas Private Investment Corporation } \\ \text { US } & \text { United States }\end{array}$




\section{Chapter One: Introduction}

\subsection{General Introduction}

In today's increasingly globalized world investors in the oil and gas sector have to take into account a number of risks when deciding to invest in a country or to expand already existing investments. Political risk is always a factor that has to be considered in decision-making processes in these companies. The success of an investment often depends on proper risk management and risk mitigation. In the oil and gas industry it is not uncommon that investments can exceed billions of dollars and take several years to complete. Because of this, political risk management and mitigation is of the greatest importance. Petroleum and mining investments are often, as pointed out by Moran (1998:70), the "most sensitive of all international corporate activities". According to Moran (1998:70), these natural resources are often seen as the country's national patrimony and investments in these sectors can often affect the country in substantial ways, compared to other investments. It can lead to increased international prestige and power and contribute to increased prosperity in a country.

The history of foreign investments in petroleum dates back to the start of the century. It began with British and German companies that were interested in getting access to the large oil reserves in the Middle East. A world-wide scramble to win concessions occurred, especially in the interwar period when many petroleum concessions were granted and all the oil-rich areas of the world were divided between the big oil companies (Lax, 1983:21). The major oil and gas reserves are located in regions that have been characterized as politically unstable. Sixty-five per cent of the reserves are located in the Middle East (Berlin, Berlin \& Vrooman, 2003). Due to this the oil and gas industry is always vulnerable; a number of risks may affect it, such as corruption, taxation systems, governmental regulations, civil and labour unrest, political instability, environmental activism, repatriation restrictions, war, external threats and terrorism. However oil and gas firms are willing to be exposed to some degree of risk as long as they are able to manage the risk and secure a profit (Alon, Gurumoorthy, Mitchell \& Steen, 2006:632). However, sometimes their attempts at risk management fail. 
One example is the In Amenas incident. In the early morning of 16 January 2013, an Algerian terrorist group named Katibat al-Mulathameen ('The Masked Brigade'), also known as al-Muwaqqi'ūn bi-d-Dimā ('Those who Sign with Blood') attacked the Statoil/British Petroleum (BP)-operated gas facility located in In Amenas, on the border between Algeria and Libya, and killed 40 workers (Chrisafis, Borger, McCurry \& Macalister, 2013). Attacks on energy infrastructure happen quite often and have been occurring for a long time ${ }^{1}$. The vulnerability of oil and gas facilities has recently received increased attention from world leaders. In a world with a constant demand for more oil and gas, the gap between supply and demand is getting smaller. Because of this tight margin a small incident may cause disruption in the supply chain, leading to increased global political and economic tension. Terrorists have taken advantage of this situation and, according to Steinhäuser, Furthner, Heidegger, Rydell and Zaitseva (2008), attacks on oil and gas installations have become the weapon of choice for terrorists all over the world.

Al Qaeda, one of the most famous terrorist organizations, has as its main goal to destroy the United States (US) and the Western economy. They have publicly stated that a means to reach this goal will be attacks against the oil and gas industry (Johnston, 2008). The attack on In Amenas can be seen as part of this larger picture. The Masked Brigade that was responsible for the In Amenas attack is an Al Qaedaaffiliated group. The leader of the group, Mokhtar Belmokhtar, was one of the leading figures in the group Al-Qaeda in Islamic Maghreb (AQIM), but because of infighting, Belmokhtar was stripped of his title. He left AQIM with his soldiers and founded The Masked Brigade in late 2012; this group now answers to Al Qaeda's senior leadership (Joscelyn \& Roggio, 2013). Because this is such a recent event, there is not much information about the group and its operations. However, it is clear that it has definitely increased the political risk for companies operating in the oil and gas industry in the region.

\footnotetext{
${ }^{1}$ An example of this can be seen in the Ogaden Basin where Ogaden National Liberation Front (ONLF) on 27 April 2007 attacked a Chinese-run oilfield. 74 workers were killed and the facility destroyed. ONLF is fighting to make the Ogaden region in eastern Ethiopia an independent state; in a statement after the attack they warned international oil companies not to enter into business deals in the region (Abullahi, 2007). Other examples are the numerous attacks on oil installations in the Niger Delta since the early 90s, caused by tension between local minority groups and international oil companies (Connors, 2008).
} 


\subsection{Preliminary Review}

In this study four broad fields of literature will be examined. The first is literature regarding political-risk analysis and political-security risk. This will provide the theoretical foundation of this study. Theories that are related to political risk, including rational choice, problem-solving and decision-making theories will be examined. The main texts that will be used to highlight political risk come from a number of highly influential scholars and include a number of works by Simon (1982, 1987) and Kobrin (1984, 1979). Work published by Robock (1971), Fitzpatrick (1983), Brink (2004), Alon and Martin (1998), Brewer (1981) and Jakobsen (2012) will also be used to extend the theoretical grounding. Political-security risk is a sub-category of political risk, and is relatively new; because of this there is a lack of literature on the topic. However, from the literature that does exist the following sources will be used: Pringle and Lambrechts (2011), The Risk of Humanitarianism: Towards an Inclusive Model, and Fouchè (2003), A Political Security Risk Analysis of Uganda. Lambrechts, Weldon and Boshoff (2010), Political Insecurity and the Extraction Industry in the Democratic Republic of Congo: Moving towards an Industry Specific Political-security Risk Analysis Model, will also be used to gain a deeper insight into political-security risk. The challenges and possibilities regarding risk management and mitigation will be covered, using mainly work done by Lax (1983) and Brink (2004), who both write extensively on the topic.

The second field is industry-specific risk in the oil and gas industry. The different sources used in this section will establish the connection between political risk and the oil and gas industry. Berlin, Berlin and Vrooman's (2003) article, Managing Political Risk in the Oil and Gas industry, will be thoroughly studied along with works by several other scholars, including Frynas and Mellahi (2003), Alon et al. (2006), and Lax (1983), who have all contributed to an expanded knowledge about industry-specific risk.

Thirdly, literature on terrorism will be consulted, with a special emphasis on terrorism aimed at the oil and gas industry. In this section the focus will be on terrorism in Algeria and northern Africa. This will contextualize the relationship between terrorism in Algeria and Statoil's activities in the country. Country reports on terrorism, published by the US State Department will also be examined. The main scholars consulted in this section will be Whittaker (2007), The Terrorism Reader, and Crenshaw (2011), Explaining Terrorism. Both works give an introduction to the complexity of the term 'terrorism' and 
will be used to clarify the term in this research study. Johnston (2008), Oil and terrorism: Al Qaeda Threat, will be used to look at the terrorist threat to the oil and gas industry and to examine the kind of impact this has on the industry. Cilliers (2010), Terrorism and Africa, will provide a broader view of terrorism on the continent while Martinez (2006), Why the Violence in Algeria; Botha (2008), Terrorism in the Maghreb: The Transnationalisation of Domestic Terrorism, and Steinberg and Werenfels (2007), Between the 'Near' and the 'Far' Enemy: Al-Qaeda in the Islamic Maghreb, will give a closer view of terrorism in Algeria and the neighbouring countries.

The fourth and final part will look at Statoil's involvement in the Algerian oil and gas industry. Literature covering Statoil's history and investments in Algeria will be examined. In this section a report, compiled by an investigation team commissioned by the Statoil board of directors and presented to the public on 16 January 2013, after the In Amenas attack, will be consulted along with information retrieved from Statoil's own webpage. Chrisafis, Borger, McCurry \& Macalister (2013) will also be used to gain a clearer picture of what happened on the day of the attack. The In Amenas facilities were jointly operated by the Norwegian company Statoil, by BP and the by the Algerian national company, Sonatrach. In this research study the focus will be on Statoil, which does not have the same experience as BP with terrorism, the study will examine how Statoil's risk mitigation and management have been affected by the incident.

\subsection{Research Problem}

In a constantly expanding global world with increased levels of foreign investment, political risk analysis becomes more and more important. The high values associated with oil and gas lead international companies to invest in countries with increased political-security risks. Africa's political instability has been seen as one of the main reasons why foreign investors are unwilling to invest in the continent (Frynas, 1998). The African continent is seen as unstable because of the number of wars, the frequent coups d'état, and the occurrence of religious and ethnic conflicts (Dupasquier \& Osakwe, 2006:250). Reinhart and Rogoff (2002), in their paper, FDI to Africa: the role of price stability and currency instability, found that wars were more likely to occur on the African continent than in any other parts of the world. However, many international companies continue to invest in the continent. As stated previously, most oil and gas 
reserves can be found in areas labelled as troubled areas. To survive in today's harsh business environment, oil and gas companies have to accept high levels of risk. This is reflected in the number of terrorist attacks aimed at oil and gas companies that have occurred this century.

According to Lia and Kjøk (2004), attacks on refineries have happened quite infrequently since 1968. This finding is based on the 'The International Terrorism: Attributes of Terrorist Events' (ITERATE) database, covering the period from 1922 until 1999. However data collection prior to 1968 is not systematic. Between 1968 and 1999 there were only twelve recorded attacks on refineries and only two of these happened in the 1990s (Lia \& Kjøk, 2004: 109). Of the 5,000 incidents recorded between 1922 and 1999, only 262 attacks targeted oil and gas facilities. However, after the September 11 terrorist attack, the focus of terror organizations shifted to oil and gas facilities (Yetiv, 2011:193). In 2004 Al Qaeda published a document entitled "The Laws of targeting PetroleumRelated Interests and a Review of the Laws Pertaining to the Economic Jihad" (cited in. Pippard, 2010), and it became a noticible increasse in attacks aimed at the oil and gas industry worldwide. These include pipeline attacks in Colombia, Russia, India, Mexico and Iraq. In Iraq alone there have been over 374 attacks on pipelines in the period between 2003 and 2006. Terrorists have targeted development and exploration sites in the Niger Delta. In 2002 the French supertanker Limburg was rammed by a small boat loaded with explosives outside Yemen, and in 2006 there was an attempted terrorist attack on the world's largest oil refinery, Abqaiq, in Saudi Arabia: a group of terrorists tried to ram two explosive-laden vehicles into the refinery. They were able to penetrate the first line of security, but were stopped before getting through the second defensive ring (Steinhaüsler et al. 2008).

This new and increasing level of political-security risk, with specific reference to terrorism, is inflicting economical loses on companies and more importantly threatening the lives of employees in the sector. The increase in terrorist attacks against the oil and gas industry has changed ways of thinking about risk in the oil and gas industry. We have gone from a period with few incidents to a period with an increased number attacks on oil and gas facilities (the extreme example being the attack on In Amenas); one may ask how this affects the industry and whether it is equipped to deal with this new reality. Accordingly, the main research question of this thesis will be: 
- What is the impact of terrorism on political-security risk management and mitigation in the oil and gas industry?

Two sub-questions have been developed to supplement and support the main research question:

- What factors contributed to the attack in In Amenas, and why was risk mitigation not successful?

- Is it possible for international oil and gas companies to mitigate the risk of terrorism, or can this risk only be managed?

\subsection{Objective and Relevance of the Study}

As been pointed out earlier, terrorist attacks against the oil and gas industry have become more frequent since Al Qaeda publicly announced that the oil and gas industry was an attractive target and a way of crippling Western economies. There are many international oil and gas companies, but the number of discoveries of major new oil and gas fields has decreased. As a consequence, the companies have to be willing to accept higher levels of risk to be able to continue to make profits. Little research has been undertaken aimed at exploring how risk mitigation and management have been affected by this upswing in the number of terrorist attacks. The main purpose of this research is to discover how, or to the extent to which, the oil and gas industries and their risk management and mitigation strategies are being affected by terrorist attacks.

\subsection{Research Design and Methodology}

The purpose of this study is to analyze the impact of terrorism on political-security risk, and to assess political-security risk mitigation and management. The methodology of the study will be predominantly qualitative and the research design will be a single case study. Most case studies that are carried out are qualitative, but this does not have to be the case. Non-case-study research is usually quantitative. Case-study research and qualitative research are not necessarily the same, but as Neuman says, "almost all qualitative research seeks to construct representation based on in-depth detailed knowledge of cases" (2011:42). Qualitative studies generate a vast amount of data focused on specific cases and because of this the findings cannot be generalized to 
other cases. A number of scholars argue that case studies can be used for forming hypotheses, which again have to be tested through other forms of research design. This may eventually lead to wider generalizations (Burnham, Lutz, Grant \& Layton-Henry, 2008:64). In the case of this research study, a case study focusing on the attack on In Amenas will be applied to provide deeper knowledge regarding risk mitigation and management in the oil and gas industry. Since the focus will be on one incident, it will not be possible to generalize to the oil and gas industry in general, but this study will provide a building block that can be used in further research on the topic. Predominantly secondary sources are used in this research for practical reasons; these have mainly to do with the limitations of doing research on political-security risk due to the fact that risk analysis bureaus keep their models a secret. Thus the study will be based on relevant data acquired from academic books, journals, and reports available at the Stellenbosch University library or found online.

In this thesis the In Amenas attack in 2013 will be used as a case study. This was one of the most severe attacks conducted against a gas installation and it produced the most serious international crisis Statoil has ever faced. Since the In Amenas episode was the most severe attack Statoil has ever experienced, it will be be interesting to examine Statoil's risk mitigation and management strategies with regard to terrorism and to see to what extent the attack has affected these. The use of a case study will enable us to link abstract ideas with the concrete specifics in this particular case. The study will be descriptive in nature. According to Neuman, descriptive research starts with a defined question and tries to answer this question as accurately as possible. The outcome of the study provides a detailed answer to the research question (Neuman, 2011:38-39). This research study is descriptive in the sense that it tries to explain the situation by looking at recent terrorist attacks against the oil and gas industry. Descriptive studies often aim to answer the 'how' and 'who' questions. The essential question to answer is how terrorism affects the oil and gas industry. Descriptive and exploratory research can often be hard to separate; more often than not they merge together. The research is exploratory in the sense that it aims to provide new insights into the topic. The focus is on a relatively new case study regarding political risk in the oil and gas industry. Lastly the research will be explanatory since the aim is to explain why political-security risk mitigation and management is important in the oil and gas industry. The purpose of explanatory research is to give an answer to the 'why' question. Why are things the way 
they are? It builds on descriptive research and tries to explain why something occurs (Neuman, 2011:40). The research will be on a micro-level since the focus in this thesis is solely on the oil and gas industry, with Statoil as the main focus.

\subsection{Limitations and Delimitations}

In this research study the focus will be on the political-risk element of political-security risk. One limitation is that the field of political-security risk has just started to attract interest, thus not much literature is available on this topic. There are very few oil and gas companies that have a specific focus on political-security risk. However, by examining the practices of these companies one is able to gain a good understanding of the extent to which oil and gas companies are using political-security risk in their analyses.

Another limitation is that this study will not have access to already-existing models used by risk units at the different oil and gas companies, or to the risk models developed by established risk firms, since these are seen as the property of the companies concerned. This limits our ability to see how and to what extent oil and gas companies are using political-security risk as a management tool. However, by using other sources, such as annual reports, surveys and journal articles on the topic, it is possible to get a good idea of how the oil and gas companies are handling political-security risk. The limited access to primary data on the topic combined with a lack of financial resources makes it difficult to conduct field studies. This problem will be resolved by using up-todate information available online and referring to journals on the topic of terrorism in the oil and gas industry and political-security risk.

\subsection{Outline of the Research Study}

In Chapter Two secondary data will be used to provide a deeper understanding of the theoretical grounding of this research study. Political risk theory is based in problemsolving and decision-making theory and it is natural to start off by conceptualizing these theories. This will be followed up by an account of risk, political risk, and macro- and micro-risk. This section will also look more closely at industry-specific or firm-specific risk and will thoroughly examine political-security risk. A conceptualization of risk management and mitigation will also be presented in Chapter Two. The chapter will end 
of with a conceptualization of 'terrorism', along with an overview of how terrorism has evolved since the term was first put into use.

In Chapter Three secondary data will be used to contextualize the research study. This chapter will contain an account of the development of terrorist groups in northern Africa and Algeria. A special focus will be the evolution of the most influential terrorist organizations in Algeria at the time of writing. This will be followed up by a close look at the oil and gas industry and how it is affected by terrorism. In particular, the chapter will look more closely at the history of Statoil and its international operations. The company's investments in Algeria and the In Amenas attack will be scrutinized in detail. Chapters Two and Three will build the foundation of the research by providing sections based on theory and on empirical findings.

Chapter Four provides a critical analysis of the data put forward in the two previous chapters, based on the theoretical framework developed in Chapter Two. Politicalsecurity risk management and mitigation in the oil and gas sector will be scrutinized, with an emphasis on Statoil's ability to effectively use political-security risk management and mitigation. The possibilities for oil and gas companies to effectively mitigate the risk of terrorism will also be examined.

Chapter Five will conclude the research study based on the research done in Chapters Two, Three and Four in the light of the research question. The results of the analysis in Chapter Four will be critically evaluated and possible improvements will be commented on. The research study will conclude with suggestions for further research in the field of political-security risk in the oil and gas industry.

\subsection{Conclusion}

In this chapter a general introduction to the research problem has been given, along with an outline of the objectives and relevance of the study; the research design and methodology has been explained, and, finally, an outline of the remaining chapters has been provided. The research problem in this study requires an analysis of the impact terrorism has on political-security risk management and mitigation in the oil and gas industry. The attack on Statoil's facilities in In Amenas in 2013 will be used as a case 
study. Two sub-questions have been developed to supplement and support the main question. The sub-questions focus more narrowly on the In Amenas attack and on Statoil's risk mitigation prior to the attack. It also looks at the possibilities for oil and gas companies to mitigate the risk of terrorism, and explores whether the only viable option is to manage the risk as best as possible.

Chapter Two will provide a theoretical foundation for the research study as well as a conceptualization of the key concepts of political risk and terrorism. 


\section{Chapter Two: Theoretical Perspectives and Conceptualization}

\subsection{Introduction}

"As a general rule, the most successful man in life is the man who has the best information" (Disraeli, 1900:153).

In future, the ability to manage and mitigate risk will probably become more important for international companies. Globalization, closer economic cooperation in the world and capital mobility have not made politics outdated. Risks such as the violent overthrow of governments, civil strife, war, civil war and terrorism will not disappear. The world has become more complex and political and social changes are happening at a faster pace and this has led to increased risks to global stability. Thus, the importance of being able to successfully manage political and political-security risk has become more important (Bremmer \& Keat, 2009). Risk management and mitigation are of extreme importance in the oil and gas industry where investments can easily exceed billions of dollars and can take years to complete. The success of the investment often depends on the appropriate use of risk management and mitigation (Berlin et al., 2003).

The purpose of this chapter is to present the theoretical foundation on which this research is based. This includes a study of rational choice theory and problem-solving and decision-making theory. The second part of this chapter will clarify the main concepts that will be used and provide a conceptualization of these. A conceptualization of key concepts like risk, political-security risk and terrorism is seen as essential to provide the in-depth knowledge needed understand the analysis that follows.

\subsection{Theoretical Grounding: Rational Choice Theory and Problem-Solving and Decision-Making Theory}

Rational choice theory has for a long time been a dominant paradigm in economics, but this has in the last few decades moved to other disciplines such as Sociology and Political Science (Green, 2002:2). Traditional economic theory put forward the "rational man". He was perceived to obtain information on the relevant aspects of his 
environment; if not complete information, at least at an acceptable level of information. He was also well organized and had a solid system of preferences, which made him able to weigh up the alternatives available to him. Based on this information, he was then able to choose the alternative that best suited his preferences (Simon, 1955:99). This schematized model provides a foundation on which to erect a theory. Rational choice theory is used as a tool, making it possible to understand the behaviour of humans. Normally rational choice theory starts with a consideration of the behaviour of a decision-making unit (Green, 2004:4); in the case of this research this unit consists of international oil and gas companies.

A major part of the daily work of business managers in both international and national oil and gas companies is to make decisions and find solutions to problems that may arise. These can range from new petroleum laws affecting a company's interest in a given country, to security questions regarding terrorism. It is up to the managers to decide on the problems that need attention. They have to evaluate and choose the best alternative and decide what actions have to be taken to reach the company's goal. Examples of this can be expanding to new regions, increasing production or/and making the company more profitable. Actions, like agenda setting, determining goals, and coming up with a plan of action, are generally referred to as problem solving, while evaluating and choosing are generally referred to as decision making (Simon, Dantzig, Hogarth, Plott, Schelling, Shepsle, Tversky \& Winter 1987:11). When a company is planning to invest in a new country, a political risk analysis is often the first part of the decision-making process with a focus on optimizing the investment. Political risk assessment on the other hand focuses on issues that call for decisions concerning the execution of an investment in a new region; in general it deals with decision-making problems (Altier, 1999; Beroggi, 1999; cited in Brink, 2004:31). Decision-making theory is according to Tversky and Kahneman "conceived as a normative model of an idealized decision maker, not as a description of the behaviour of real people" (1986:251). Nevertheless, it is a tool that helps to provide knowledge about why certain decisions are taken.

A common argument supporting normative analysis is that people in general are thought to be effective when pursuing their goals, especially when they are able to learn from former experiences. As a result, it seems sensible to describe choice as a maximization process. In this process a multinational oil and gas company is assumed to have a 
stable system of preferences and an ability to calculate which of the alternative courses of action available to the company that will provide the best outcome for the company (e.g. investments in new oil fields, the provision of new equipment, or expanding to new countries) (Simon, 1955:99). Furthermore, competition favours individuals and organizations that act rationally. The best decisions will result in increased profits in a competitive environment (Tversky \& Kahneman, 1986:251). In the decision-making process the rational actor will focus on minimizing uncertainty by applying expert knowledge to the topic. If the decision-maker is not able to reduce the uncertainty to a level of reasonable risk, the investor will abstain from investing in the country or, if already in the country, will consider pulling out (Brink, 2004:30). These uncertainties may be a result of insufficient knowledge or of the process occurring in the decisionmaking environment in question. A way to reduce this uncertainty is to follow the steps involved in decision-making. According to Chicken (1986) this involves conceptualizing a plan to invest in new projects or to expand already-existing operations, using either internal or external actors to conduct a study to determine the possible outcomes and to plan how to implement the decisions that have been taken (Chicken, 1986; cited in Brink 2004:30).

Simon et al. (1987) also come up with a six-step process to reduce uncertainty:

- Find out what the problems or opportunities are.

- Collect information.

- Develop as many alternatives as possible.

- Evaluate the alternatives.

- Decide which one is the best.

- Implement the chosen alternative and follow up on it.

(Simon et al., 1987:11).

A decision-maker has to consider different alternatives, calculate what might happen when applying different alternatives, resolve uncertainty that might occur and in this way come up with a solution that will satisfy the investors (Simon, 1979:511). Political risk analysis provides the decision-maker with information which highlights the different political risks that may affect the profitability of a project for the specific company. When the company has been provided with this information, strategies on how to manage 
these risks have to be developed (Brink, 2004:30). This research study will address the uncertainties preventing oil and gas companies from successfully managing the risk of terrorism through the use of political-security risk management and mitigation tools.

\subsection{Risk}

In the 1980s the subject of risk started to become of great concern in all types of industries and was being discussed at all levels of government. A number of different kinds of risk emerged. These included investment risk, business risk, safety risk and political risk (Kaplan \& Garrick, 1981:11). However, this research study will focus on political risk only. Risk by itself is often used to refer to a "change of injury, damage, or loss, compared with some previous standard" (Lax, 1983:8). Chicken (1996) supplements this definition and defines risk as "the manifestation of doubt regarding the frequency and consequences of undesirable events..."(cited in Brink, 2004:17). In addition, there are a number of very broad definitions of risk: for example: "Risk is the probability that any event will turn into measurable losses" (Bremmer \& Keat, 2009:4).

According to Hough, risk refers to uncertainty concerning a particular event and the consequences of this event (2008:1). The concepts 'risk' and 'uncertainty' have at times been used as synonyms or have been seen as closely related concepts where they represent different levels of intensity or impact. The difference between risk and uncertainty has normally been based on outcome probability and is in fact seen as indicating two levels of uncertainty: that is, instances where the outcome probabilities are known and instances where these probabilities are unknown. As a result, the term 'risk' should be used in situations where the probable outcomes are uncertain and where the outcome is to some extent unknown and will lead to negative outcomes (Hough, 2008:4-5). According to Kaplan and Garrick (1981) risk involves both uncertainty and some type of damage or loss to an investor's property. They use an equation to explain the difference between risk and uncertainty.

Risk = uncertainty + damage (Kaplan \& Garrick, 1981:12).

An example is where several oil and gas companies are competing for an extraction concession from a given country. While the country's government is deciding to whom 
to give the concession, the companies are in a state of uncertainty but are not facing any risk. Uncertainty deals with a potential loss, while risk, on the other hand, deals with measurable probabilities. The difference between risk and uncertainty can sometimes be hard to distinguish and may seem rather academic, but there is one important difference. Both terms refer to future likelihoods, but with risk one is able to calculate probabilities and because of that one is able to protect and prepare for future eventualities; with uncertainty it is not possible to do this (Lax, 1983:8). However, uncertainty can in some cases be a positive factor. If risk encompasses actions where the outcome is uncertain, then the risk taken in a profitable environment might be rewarded. If one is able to manage these uncertainties properly the possibility to exploit them becomes a reality (Brink, 2004:21). Often smaller oil and gas companies are more willing than the larger ones to take the risk of investing in regions regarded as high risk. They accept the high risk in the hope of getting a high return (Bray, 2003:299). Cairn Energy's investments in the Sangu gas field in Bangladesh can be seen as a successful and profitable example, where high risk was rewarded with high returns ${ }^{2}$ (History Bangladesh, 2014).

\subsection{Political Risk}

The term 'political risk' is frequently used in international business literature, but agreement as to its meaning is, according to Kobrin (1979), limited to the implication of undesirable results arising from political activity. According to Alon and Martin (1998) three problems were identified in early definitions of the term. First, the political risk was too narrowly defined. Due to this the conceptualizations were inappropriate, wrong data was used, and the results were misinterpreted. Secondly, as stated in the previous section, the assumption that political risk only leads to negative outcome for the firm is not always correct. A number of scholars support this, including Robock (1971) and Fitzpatrick (1983). An example of this can be a transition from a communist regime to a market economy. It will be much easier for international oil and gas companies to get access to petroleum reserves in a country where a market economy has been introduced. The third argument is that the focus on government policies and political

\footnotetext{
2 In 1994 Cairn Energy signed a product sharing a contract for two blocks offshore Bangladesh. In1997 they transferred their operations to Shell and the two companies went into a partnership to operate two new blocks (Cairn Energy, 2014).
} 
events draws attention away from other causes of political risk (Alon \& Martin, 1998:11; Brewer, 1981:5).

The concept of political risk has been constantly changing since it was introduced. It has evolved from being general country risk to include more specific sub-classifications. Political risk is often confused with country risk, though they are quite different. Country risk can be described as sovereign, transfer and credit risk and differs from political risk in that it can refer to possible financial losses caused by complications arising from macro-economic events (Brink, 2004:19). Countries that have a good record of paying back loans pose less country risk and are able to get access to new loans more easily than countries that have a lower creditworthiness. This shows that country risk indicates the inability to repay loans, while political risk on the other hand relates to a country's unwillingness to do so. High levels of country risk do not necessary mean high levels of political risk, and vice versa (Brink, 2004:23).

Political risk is most commonly thought of in the relationship between host government and foreign business companies (Kobrin, 1979:67; Fitzpatrick, 1983:249) and at its origin, nationalization and expropriation were seen as the two major sources of political risk (Alon et al., 2006:624). The definition provided by Weston and Sorge (1972) illustrates this well: "Political risk arise from the actions of national governments which interfere with or prevent business transactions, or change the terms of agreements, or cause the confiscation of wholly and partially foreign-owned business property" (Weston \& Sorge, 1972, cited in Kobrin, 1979:67). A number of other scholars agree with Weston and Sorge and define political risk as government interference in business affairs; they argue that this is the main direct cause of investor losses and this makes it the main cause of political risk (Poynter 1982; Robock 1971). Other analysts have questioned this view and argue that too much attention is given to political instability. They argue that the events most commonly associated with such instability occur rather infrequently (Lax, 1983; Kobrin 1979, 1981). A focus only on dramatic events like coups or revolutions meant that less dramatic or eye-catching events, (but events which were equally damaging and happened more frequently), were overlooked and under-analyzed (Jakobsen, 2012:30; Kobrin, 1981:253). This was evident in Kobrin (1981), who conducted a survey among managers of large international companies, asking them to list twelve potential contingencies. The majority ranked civil disorder as number one and 
external war as number two. None of the other contingencies even came close to these two (Kobrin 1981:252).

A second category defines political risk in terms of events that are political acts and /or restrictions forced on the company. They identify political risk with factors such as direct violence, instability, or limitations placed upon foreign business. This can take the form of expropriation, discriminatory taxation or restrictions on remittance of profit, but it can also be non-focused, such as in the case of riots (Fitzpatrick, 1983:249).

A third category focuses more on political risk in the terms of a whole environment rather than isolated events. This category is well represented by Robock (1971), who states that political risk exists when a disruption happens in the business environment due to political change. This is normally difficult to anticipate. This change is a risk if it affects the company's goals or profits to a significant extent (Robock, 1971). An example of this was the devaluation of the Russian rouble in 1998. Leading economists had reassured international investors that the Russian government had the ability to repay bonds held by international investors. However on 17 August 1998 the Russian government devalued the rouble and declared a moratorium on payments to foreign creditors. The consequences for investors were immediate and devastating. According to Robock, political risk exists in international business: "(1) when discontinuities occur in the business environment; (2) when these are difficult to anticipate; and (3) when they result from political change"(1971:7). There are also those who do not use a concrete definition, but acknowledge that the political conditions in a country may pose a risk to the company (Green \& Smith, 1972). Still, most political risk authors agree, as stated in Brink (2004), that "political risk broadly supposes the probability that business will either earn less money, or suffer losses in profit as a result of stakeholders within a political system's (in)action or reactions to events, decisions and policies"(2004:18)

Political changes that do not affect the business environment should not be seen as political risks for international companies, since this goes against the characteristics identified in Robock's definition. Frequent changes of government do not in themselves pose a threat to international companies. As Lax (1988) argues, the same goes for street protests and political violence, which are hardly ever directed against the business community; therefore business can continue as usual. 
Since the 1990s scholars have began to recognize government intervention and policies as the most common forms of political risk. (Jakobsen, 2012; Butler \& Joaquin, 1998; Wells, 1998). Nowadays low-key changes are a bigger threat to international companies than events staged by non-governmental groups, events such as terrorism, sabotage and kidnappings. This is despite the fact that mass expropriation has almost ceased to be a problem (Jakobsen, 2012:31). Even though terrorism does not affect businesses to the same extent as low-key government changes, it is of such a nature that when it first happens its effects are often very severe and can cost companies millions of dollars; in worst cases it can result in the killing of employees.

Alon et al. (2006) state that the political risks facing international businesses can be identified along several fronts. These may include rules and regulations within a country; security issues; interstate or intrastate war; the economic policies of the government; trade barriers, etc. These are factors that affect all foreign companies in the country, but the extent to which the company is affected will depend on which sector the company is involved in (Alon et al. 2006:625). For example, an oil company will be more at risk of a terrorist attack or a civil war. The attacks on Baron Oil's operations in the Nancy Burdine Maxine Fields in Colombia in 2013 show the importance of focusing on the risks resulting from terrorism ${ }^{3}$ (Mclvor, 2013). International banks and international financial trusts for their part will be more concerned with risks such as the balance of payments, hyperinflation, interest rate changes, and market liquidity when considering an investment. An example of this type of risk, as presented in Alon et al. (2006:629), is the 40 per cent devaluation in currency that hit Brazil in 1999; this was caused by a bailout by the International Monetary Fund (IMF) in the same year, leading to an unfriendly investment climate.

In this section a number of definitions have been presented. For the purpose of this study Simon's (1982) definition will be used. This is because it differentiates between

\footnotetext{
${ }^{3}$ Baron Oil is the largest operator at the Nancy Burdine Maxine Fields and at the end of 2013 experienced a number of attacks on its production facilities by the Colombian terrorist group Fuerzas Armadas Revolucionaria de Colombia (FARC). These caused a temporary halt in production and damaged the facilities. Several workers were injured as a result of the terrorist attacks (Mclvor 2013).
} 
macro- and micro-political risk and because of its broad environmental scope, as will be explained below. Simon states that "political risk can be viewed as [resulting from] governmental or societal actions and policies, originating either within or outside the host country, and negatively affecting either a selected group of, or the majority of, foreign business operations and investments" (1982:68).

\subsection{Political-Security Risk}

As seen above, political risk has evolved to include conceptual changes, in order to adapt the discipline to fit into today's world. A number of new types of risk have been identified; one of these is political-security risk (Lambrechts, Weldon \& Boshoff, $2010: 110)$. The field of political-security risk is still relatively new and as a result, there is little literature on the subject. Fouché (2003:18) describes political-security risk as "those vulnerabilities that flow from the political risk (policy responses to security threats) that are found in a specific country [...] these could include, amongst others, political actions such as unpopular legislation leading to widespread unrest, restrictions on political parties leading to civil unrest, labour actions and even terrorism". Fouché (2003) further focuses on the political-security components of traditional political risk, even though political-security risk stands on its own as a separate type of political risk; it must include several political risk elements in order to provide a correct analysis.

In his research study, Fouché discusses the two elements of national security and human security. These elements are incorporated by Lambrechts et al. to provide a more overarching definition. Lambrechts et al. (2010) divide political-security risk into three categories of security: transnational security, national security and human security. In transnational security the region is the main actor and factors likely to impact the region are analysed. An example of this is a border dispute. National security focuses on the state as the main actor and on problems that can arise both internally as well as externally. Human security sees the individual as the main actor and emphasizes the protection of individuals against threats such as ethnic rivalry. All these risks may evolve into risks affecting the investments of foreign companies.

Both transnational security and national security fall within the traditional conception of security which has its origin in political realism; it identifies security from a state-centred 
perspective and limits the use of security to the military realm. This might include the protection of state territory and a focus on preserving national values and interests (Pringle \& Lambrechts, 2011). As argued by Leone (2010:100), transnational security is also in line with a shift to a more post-sovereign focus on security; this looks at a globalized, post-Cold-War scene where multi-level authorities and unexpected events are weakening state sovereignty.

The last type or level of security is human security, seen by many as the major element in national security (Fouché, 2003:17; Mathur, 1996:333). Human security focuses on elements that are not emphasized by transnational and national security. After the cold war the focus shifted towards human security as the traditional security perspectives failed to match up to the new security challenges in the world (Pringle \& Lambrechts, 2011: 55). Kaldor's (2012) attempt to describe this new security challenge is useful: she argues that during the last decades of the twentieth century, the world and especially Africa and Eastern Europe, have witnessed the evolution of a new type of organized violence. She coins the term "new wars" to describe this type of violence (Kaldor, 2012:1). These "new wars" can be seen as different from earlier wars in "terms of their goals, the methods of warfare and how they are financed". Often these "new wars" are about identity politics, either religious or linguistic; they differ from the "old wars" where geo-political and ideological goals were the focus (Kaldor, 2012:7). One of the characteristics of these "new wars" has to do with how the mode of warfare has changed. As argued by Kaldor (2012:9), terrorism can be seen as a form of this new strategy. Through spectacular, often horrible, acts of violence terrorist groups are trying to generate fear and conflict.

According to Fouché (2003), the main security challenges to the national interest emerge from issues related to mass-migration, political oppression and terrorism. As a result, the definition of security should reflect a broader view that takes into account the need for freedom from vulnerability in modern society (Fouché, 2003.17). The human security approach tries to change the traditional idea of security, where the focus is on national and regional stability, to put more emphasize on the human being. This means that the main challenges no longer have to do with military forces; the primary threats are now seen as domestic. These include human rights violations, economic failure and political discrimination. National security is no longer guaranteed only by military power, 
but also depends on political, social and economic conditions (Tadjbakhsh, 2005:5). Uzodike and Isike (2009) sum it up well: "The human security conceptualization accommodates a wide range of issues that not only constitute threats to human existence, but also breed insecurity and societal anarchy" (2009:106).

Transnational security, national security and human security are not mutually exclusive, as Pringle and Lambrechts argue (2011), but mutually reinforce each other. Each element is important; together these elements bring about a better definition of security. Pringle and Lambrechts combine these three elements in a comprehensive definition of political security risk:

Political-security risk consists of interrelated security risks, including transnational, national and human security. It is caused or influenced by government or societal political decisions, politics, (in)actions, reactions, or other unforeseen events and can originate either within or outside the host country, [impacting either a selected foreign company or a selected group of foreign companies]" (Pringle \& Lambrechts, 2011:56).

This research study will focus more on the security elements of political risk and on the political-security risk branch of political risk. Thus this definition will be used and in conjunction with the previously stated definition of political risk.

\subsection{Macro and Micro Political Risk}

When investing abroad, international companies may encounter both macro- and micropolitical risks. An unexpected change in the political environment that affects all foreign businesses is called macro-political risk. A micro-risk is identified as an environmental change that affects only a specific industry or a specific company (Robock, 1971:9). Examples of macro-risk are large-scale disruptive socio-political events like revolutions, interstate and intrastate wars and substantial changes to investment rules affecting all foreign companies in the country. Examples of micro-risk include selective expropriation, terrorist attacks against oil and gas installations, tax increases aimed at oil companies, and price controls for utilities (Jakobsen, 2012:38). Macro-risks can be irregular and indirect. Especially when a country is experiencing political unrest, foreign companies 
are tempting targets for groups from all parts of the political spectrum. On several occasions, the property of foreign investors has been damaged to embarrass the regime in power. An example of this type of indirect political risk took place in Argentina in 1969, when several US companies that owned supermarkets were bombed as a consequence of the visit of Governor Rockefeller to Buenos Aires (on behalf of President Nixon). The supermarkets were owned by a company Rockefeller had founded (Robock, 1971:9).

Macro-risk can be further divided into two categories, internal and external risk. Internal risk focuses on causes that are domestically generated, while external risk can be attributed to the home country, a third country, or to the global environment (Alon \& Martin, 1998). Simon (1982) took these two approaches and combined them and concluded that political risk can result from either society-related or governmentalrelated factors.

Robock's (1971) differentiation between macro-political risk and micro- political risk was an important as it demonstrated to international investors the importance of paying attention to subtle changes in industry-specific conditions, as opposed to changes brought about by large-scale catastrophic events (Simon, 1982:66). It also showed the broad scope of political risk, extending from revolutions which may affect all foreign businesses to a tax law that affects only one (or a few) foreign businesses. The risks generated by military or social groups, through military coups or revolutions, can evolve into macro-risks if the new government chooses to nationalize or expropriate foreign businesses, but this is more the exception than the rule. More common is selective nationalization or "creeping" nationalization and indigenization (Simon, 1982:67). Kobrin (1981) argues that most of the political risks faced by foreign companies entail microrather than macro-risks and mostly affect operations rather than ownership (Kobrin, 1981:253). Kobrin (1984) analyzes expropriations between 1960 and 1976 and argues that the actual extent of expropriations has been surprisingly limited. In the period between 1960 and 1976 only five per cent of all firms owned by foreign investors in developing countries were expropriated; in most cases this happened at the beginning of the 1970s. However, after 1975 there was a remarkable decrease (Kobrin, 1984:329). Kobrin's assumption that the decline would continue was confirmed by Minor (1994), who looked at data from the period between 1980 and 1992. The data indicated that it was unlikely that expropriation would resurface in the near future. Since the 1990s 
developing countries have increased the degree of protection of foreign companies from expropriation. The broad trend in developing countries towards privatizing state-owned firms indicates that the governments are unlikely to disrupt private-sector activity and enter into state ownership (Minor, 1994: 177). Even though there has been a decline in the number of expropriations, the risk of expropriation is still present. According to Bremmer and Keat (2009) a clear "convergence" process where privatization becomes the order of the day is unlikely to happen anytime soon. The environment of foreign investment is becoming more diversified and complex (Bremmer \& Keat, 2009:125). In 2006 the Ecuadorian government expropriated all the assets at block 15 from the American oil company Occidental Petroleum (Oxy Drops Petro-Ecuador Suit, Focuses on Government Case, 2006). These cases demonstrate that expropriations still occur. Although expropriations have been in steady decline since the beginning of the $90 \mathrm{~s}$, they still are responsible for 84 per cent of the amount paid out in risk insurance by the American Overseas Private Investment Corporation (OPIC) (Bremmer \& Keat, 2009:125). Thus, the risk of expropriation is still present, although there has been a decline in the last couple of decades.

According to Jakobsen (2012), this distinction between macro- and micro-risk more or less follows the earlier division between those who claimed that political instability was the main political risk and those who believed that the risk of government intervention was more important. Events associated with macro-risk often tend to be more spectacular and eye-catching, and are of course important in their own right, while micro-political risks stem from less high-profile and less newsworthy events. These occur more frequently and often inflict much higher losses on the affected firms. It is more common to encounter micro-political risk; this is in contrast to comprehensive expropriation, such as mass nationalization, which has been in decline. But even though it is declining such risk it still exists. An example is the Bolivian nationalization of the country's gas fields (Alon et al., 2006:626), which was the beginning of the nationalization of all foreign-owned energy reserves in the country.

Micro-political risk can also be referred to as industry-specific risk, or it can be referred to as firm-specific risk as done by Berlin, Berlin and Vrooman (2003). The risk varies from industry to industry and, according to Lambrechts, Weldon and Boshoff (2010), two factors are likely to affect political risk over time. The first is that the higher the share of 
foreign-owned businesses in a country, the greater the change that the industry will experience from increasing micro-political risk. Secondly, the more skilled the local workforce and the more it is able to run the businesses successfully, the higher the micro-risk becomes (Lambrechts et al., 2010:112). In this study the focus will be on micro-risks, since terrorism in the oil and gas industry, which is the focus of this research, is most often targeted at specific facilities, such as oil tankers, pipelines or oil and gas refineries. The next section will provide a more thorough explanation of industry- and firm-specific risk.

\subsubsection{Industry- or Firm-Specific Risk}

Frynas and Mellahi recognize that the risk to companies varies according to the type of project, the kind of company, even the product lines (2003:542). As stated by Kobrin, "the impact of most political events varies from firm to firm and from project to project" (Kobrin, 1982:40). In their study Robock and Simmonds (1989) found out that significant political risk in some countries affected some types of businesses less than others. An example is the political unrest in El Salvador in the 1970s and 1980s (Robock \& Simmonds, 1989). Robock and Simmonds are supported by Kobrin (1980) who states that in several cases companies chosen for expropriation were selected according to their type of business. Specific companies were expropriated for specific reasons. Frynas and Mellahi state this clearly: "It has been recognized in general terms that risk assessment, as part of the investment decision process, is highly project-specific and occasionally firm-specific or even product-specific" (2003:542). Frynas and Mellahi conclude, by looking at oil companies in Nigeria, that companies exposed to the same political events may be affected differently, depending on the resources and capabilities available to the company. They found that Shell had an advantage in Nigeria because they considered political risk to be a firm-specific risk and their interest in investing in Nigeria may to some extent be explained by their firm-specific risk assessment or their capacity to reduce risk (2003:559). In addition, Alon and Herbert (2009) argue that guidelines for a systematic approach to assessing the specific risks facing a specific firm are sorely lacking. Frynas and Mellahi state that scholars should put more focus on studying political risk at the firm level instead of only at country and industry level (2003:562). They are supported by Alon and Herbert (2009) who argue that surprisingly little research has been done to identify firm-specific political risks. 
Alon et al. (2006) look at the industry-specific risks relating to the oil and gas sectors and argue that the oil and gas industry is one of the most sensitive sectors to invest in (2006:631). They are supported by Moran (1998: 70) who states that, because the resources involved often are viewed as part of a country's national patrimony, investments in this sector are more likely to affect the country more than other investments (due to the wealth and power that accrues from the production of oil. The oil and gas industry faces a number of risks; these include corruption, terrorism, repatriation restrictions, government regulations and environmental activism, to name a few. These are macro risks that can affect almost all sectors, but risk variables. such as oil embargos, restrictions on oil export, energy vulnerability and environmental activism are specific to the energy sector (Berlin et al., 2003; Alon et al., 2006). As Berlin et al. state (2003:2), political risk plays an increasingly important role since the production of oil is linked to the geopolitical location of reserves; major reserves are located in politically unstable regions of the world. Oil and gas companies are willing to be exposed to a high degree of risk as long as they are able to manage the risk and make money (Alon et al., 2006:632).

It is of crucial importance that international companies are able to reduce their vulnerability to political risks. The importance of this can clearly be seen in the terrorist attack against Statoil's In Amenas facilities; as explained in the first chapter, this attack will be the focus of this study. To organize a terrorist attack against a whole industry is almost impossible. Risk at the macro-level usually applies to bigger entities or events like governments, war or civil war and the like. It is easier for terrorist groups to conduct attacks against specific companies, like Statoil in In Amenas. Because terrorist attacks against companies normally centre on one facility, owned by one company or a few companies, it is natural that the focus in this research study will be on industry-specific risk. To be able to reduce their vulnerability to this risk, companies need a riskmanagement and mitigation framework. In the next section these two concepts will be outlined. 


\subsection{Risk Management and Mitigation}

Risk management is one of the most important objectives of oil and gas companies with investments all over the world (Miller, 1992:311). In today's global marketplace it is crucial that international companies and investors consider the political risks involved when making investments. Risk must be continuously assessed in international companies' decision-making processes. For companies to decide on the best way to manage and mitigate risk, it is of the utmost importance to ensure the success of new investments or to grow already-existing foreign investments (Berlin et al., 2003:1). Haendel (1979:135) defines risk management as "identifying risks, assigning a value to them, anticipating losses, and making objective decisions about what steps to take before losses occur so that they have the least impact on the operations of the enterprise ".

Political risk management can be seen as the preventive actions international companies and investors take to keep the risks associated with their investments and activities at an acceptable level (Brink, 2004:149). These activities include: the implementation of plans to expand abroad; the host state's reaction to these activities; and different policy actions that have a negative impact on the profitability of expansion. From a political-security risk-management perspective, actions from non-state actors, like terrorist groups; or political discontent at state authorities (leading to riots and military actions by foreign military forces), are activities that must be at an acceptable level before a company chooses to invest. Political-security risk management is especially important in the oil and gas industry, because the world's oil and gas reserves are located in regions of the world that are seen as unstable (Berlin, et. al., 2003:2). The largest oil and gas reserves in the world can be found in the Middle East, in the former Soviet states, in South Asia and in Africa (Luft \& Korin, 2003). These are regions where countries have experienced a number of successful or foiled terrorist attacks.

There are a number of different ways to protect a company against political and politicalsecurity risk. Accordingly, the decision on what mitigation measures to take has to be made after a thorough assessment and consideration of the different factors that may affect the company's investments in the host country (Berlin, et. al., 2003:6). According to Berlin et. al (2003), there are two ways to manage political risk. The first is through 
political risk insurance or through what Berlin et al. call de facto insurance. This can be described as the protection provided by well-thought-out partnering or planning. Political insurance does not focus on preventing a loss, but rather on ensuring that the investors are compensated for losses that might occur. De facto political insurance on the other hand tries to prevent losses from occurring in the first place. Political risk insurance and political insurance are not mutually exclusive, but complement each other in many instances (Berlin et al., 2003:6). Berlin et al. (2003) two ways to manage political risk has much in common with Brink's (2004) two techniques. Brink distinguishes between integrative and protective management of political risk. Integrative techniques focus on limiting the frequency of loss and the main objective is to influence relations with the political leadership in a given country. Protective techniques are concerned with minimizing the severity of losses and focus on securing the internal strengths of (in this research study) international oil and gas companies.

The aim of integrative techniques is to increase the integration of the company into the host country. The idea is that the host government then will look at the company as being less foreign and this (it is hoped) will reduce the risk of government intervention. Examples of integrative techniques used by international companies include local sourcing; following good labour policies; making a thorough expatriate selection; encouraging export promotion and engaging in joint ventures with local state companies (Brink, 2004:156). In the oil and gas industry joint ventures are very common. At Statoil's gas extraction facilities in In Amenas, Statoil is now engaged in a joint venture with the state-owned company Sonatrach and with BP (Statoil, 2013b).

The aim of protective techniques is to deter the host government from placing restrictions on the international company. In cases where the government does interfere, the goal is to minimize losses and to hinder the integration of the foreign company into the host country's environment. Examples of this strategy include withholding technology as long as possible; subcontracting parts of the production process; and making use of financial tools. This may mean involving other companies in the venture and gradually entering new countries (Brink, 2004:157). As with Berlin et al., the two techniques described by Brink (2004) can be combined: it is in the interest of the international company to come up with a risk management strategy that combines integrative and protective techniques for the country it is planning to invest in. 
The tendency among companies has been to conduct risk analysis as a response to a specific situation rather than maintaining a constant political risk management function. These forecasts on request come as a response to the particular needs of investors. The request normally comes when new investments or the upgrading of existing investments are considered. Due to the failure to look at risk management as an ongoing function, including the observation of changes and the continuous updating of analysis, companies often fail to manage problems before they become apparent. Often international companies react to incidents when they occur, instead of trying to forecast and prepare for incidents that might happen in the future. After the company has made the investment, the different political risks that might face the company are often given little attention, until a severe incident happens which affects the company's assets (Lax, 1983:174). This is evident in the case of the In Amenas terrorist attack. According to Bousso (2013), Statoil had for years a political risk unit that was part of the communication department, but according to a source in the company this was recognized more as a PR issue and less as a risk-management tool.

When looking at the number of incidents and the importance of political events affecting the international oil and gas industry, one would hope that companies were making an effort to develop political risk management strategies. However, despite having recognized the risks, many companies still have not advanced beyond forecasting political developments (Lax, 1983:174). Companies extracting oil and gas have little freedom when it comes to managing political-security risks. These companies operate in an industry that has to extract the raw materials where they are found; they cannot choose to move their production facilities out of the country if something happens, like for example expropriation, or substantial changes in investment rules, or in the event of interstate war, revolutions, terror attacks, etc. However, this does not mean that oil and gas companies have no way of minimizing their risks. Their risk management tools might be limited, but the companies are able to take an active role in reducing their vulnerability to political-security risks. One of the most severe political-security risks that oil and gas companies face is the risk of terrorist attacks. In the next section the term 'terrorism' will be discussed as well as the evolution of the concept over the last century will be explored. 


\subsection{Terrorism}

In this research study the aim is to find out how terrorism affects political-security risk management and mitigation in the oil and gas sectors. To be able to do this one has to have clarity about the concept of terrorism. The purpose of this section is to provide this clarity.

The term 'terrorism' has caused confusion and contradiction ever since it was introduced into the political vocabulary. The main reason for this is that the meaning of the term has changed frequently over the years. The origin of the word can be traced back to the French revolution and the "reign of terror" (la Terreur),but it has since acquired different meanings for different people at different times (Gupta, 2008:5). After the Second World War the term 'terrorism' mostly referred to the violent uprisings that were conducted by various nationalist and anti-colonialist groups in Africa, Asia and the Middle East, in opposition to European rule in the late 1940s and 1950s. Algeria, Israel and Kenya are some of the countries that obtained their independence partially thanks to national groups that employed 'terrorism' against their colonial rulers. It was during this period that the term 'freedom fighter' became fashionable. Many of the newly independent third world countries argued that any people who fought against colonial oppression should rather be regarded as 'freedom fighters'. In the 1960s and 1970s terrorism was still being used in a revolutionary context, but now the context expanded to include ethnic separatist and nationalist groups that were not part of a colonial or neocolonial struggle. Groups such as FLQ (Front de Liberation du Quebec) and ETA (Euskadita Askatasuna) were now defined as 'terrorist' (Whittaker, 2007:6). In the early 1980s terrorism was extended to include less distinct phenomena and came to be regarded as calculated means to destabilize the West as part of a bigger global conspiracy. After a number of suicide bombings against American embassies and military bases in the Middle East in the mid-1980s, the focus shifted to state-sponsored terrorism. States such as Iran, Iraq and Syria became active sponsors of terrorist attacks. Terrorism came to be seen as a form of surrogate warfare where smaller states were able to challenge more powerful states (Whittaker, 2007:7). Since the meaning and usage of the term have changed over the decades, it is not very surprising that it has become increasingly difficult to define. 
In an often cited book published in 1988, Schmid and Jongman looked at 109 different definitions of terrorism and found an extreme lack of uniformity among the definitions provided by state agencies, academic scholars and a number of think tanks (Schmid \& Jongman, 1988). Below is a selection of different definitions which show the broad spectrum:

- $\quad$ "The use or threat, for the purpose of advancing a political, religious or ideological cause, of action designed to influence a government or to intimidate the public or a section of the public, which involve serious violence against any person or serious damage to property" (Security Service, MI5, n.d.).

- "The threatened or actual use of force or violence to attain a political goal through fear, coercion or intimidation" (Russell, Banker \& Miller, 1979: 4).

- "Involves political aims and motives. It is violent or threatens violence. It is designed to generate fear in a target audience that extends beyond the immediate victims of the violence. The violence is conducted by an identifiable organization [...] involving a non-state actor or actors as either the perpetrator, the victim or both" (Bhatt, 2007:14).

- "The repeated use of politically motivated violence with coercive intent, by nonstate actors, that affects more than one state" (Badey, 1998:92).

As seen here, there is a wide range of definitions attempting to conceptualize 'terrorism'.

On September 11, 2001 the US experienced the most devastating terrorist attack in its history. Approximately 3,000 people were killed. This is a large number, but compared to the number of murders in the US every year it pales into insignificance. Over 14000 people were murdered in the US in 2012 (FBI, 2012). Despite the fact that more people 
were killed in the US in 2012 than there were terrorist deaths worldwide $^{4}$, terrorism receives a tremendous amount of attention. One of the reasons for this is that terrorism varies from other types of violence in its extra-normal quality. Thornton explains, "terrorism [...] lies beyond the norms of violent political agitation that are accepted by a given society" (1964:76). Acts of terrorism are both politically and socially intolerable. Terrorist attacks are frequently extremely brutal and psychologically shocking. This may include mutilation of victims, the use of suicide bombers, and throat cutting. The attacks are normally aimed at the civilian population and happen unexpectedly, making them difficult to predict. These factors make terrorist attacks unacceptable and abnormal (Crenshaw, 2011:23). The psychological aspect of terrorism attracts a lot of the attention. Terrorism creates an extreme fear in the minds of people. This fear is not primarily intended for the terrorist victims, but for a larger audience that might not even know the victims. An important aim of the terrorist attacks is to create fear in a population (Ruby, 2002:11). According to Crenshaw (2011:23), these attacks are intended to affect the political behaviour and views of a particular group or of several groups in order realise the goals of the terrorist organization. The most important target is the civilian population, which is easy to access and where it is possible to harm a large number of victims.

In this research study the definition of terrorism provided by the US State Department, will be used: "Politically motivated violence perpetrated against non-combatant targets by sub-national groups or clandestine agents, usually intended to influence an audience" (US Department of State, 2012). This definition is composed of three key criteria. The first is that terrorism must be politically motivated. Terrorism has been regarded as "the continuation of politics by other means" (Bhatt, 2007:15). Bhatt (2007) argue that the most important elements separating terrorist attack from other types of violence is the political goals of the terrorist organization.

The second criterion is that the violence is directed against non-combatants. Noncombatants are people who are not part of the military or military members who are not part of military hostilities. Here terrorism is seen as attacks waged against the civilian

\footnotetext{
${ }^{4}$ According to National Consortium for the Study of Terrorism and Responses for Terrorism (2013), there were 11098 casualties worldwide in 2012. Although casualties were recorded in 85 countries, over half of all the fatalities (62\%) took place in only three countries: Pakistan, Afghanistan and Iraq (2013).
} 
population, which is not prepared to defend themselves against such attacks (Ruby, 2002: 10).

The third criterion is that perpetrators are a sub-national group or clandestine agents. This means that the political violence carried out by nation-states is not regarded as terrorism. This includes attacks where civilians might be killed (e.g. the NATO bombing of Libya in 2011). This part of the definition is more controversial than the others. The US support of the Contras in Nicaragua (who spread fear among the population regarding what would be done to them if they joined the Sandanista rebel group) can be seen as an example on how this part of the definition is sometimes less than satisfactory (Held, 2004:63). According to Ruby (2002) national entities fit into the clandestine description just as sub-national entities do. If agents from one state bomb a grocery store in another country in order to change the policies of that country, this does not fit into the sub-national group description, but will be regarded as terrorism nevertheless (Ruby, 2002:11). The most important element here is that terrorist groups behave in a clandestine way.

Terrorist acts become attractive when it seems there is no other means left to achieve the goals of the group. Terrorism can sometimes be seen as a tool to be used in states where there is no political freedom for opponents of the regime (e.g. FLN struggle against the French colonial regime). However terrorism also happens in countries where political opposition is allowed (e.g. 9/11 attack in the US in 2001, the London bombings in 2005). The definition of the term 'terrorism' has been the centre of discussion for decades, but according to Whittaker people agree on one point: " [terrorism] is a word with intrinsically negative connotations that is generally applied to one's enemies and opponents, or to those with whom one disagrees and would otherwise prefer to ignore" (2007:7). The aim of this section has been to provide a deeper understanding of the evolution of the complex concept of terrorism and to give an insight into an ongoing debate. In this research study the definition by the US State Department will be used on account of its simplicity and because it matches the terrorist attack in the case study. 


\subsection{Conclusion}

The objective of this chapter was to give a conceptualization of the key terminology, as well as to clarify the theoretical grounding of this research study. Rational choice theory, problem-solving and decision-making theory have been examined to create the theoretical framework for the research. This was followed by a conceptualization of the key terminology that will be used in this study. The concepts include risk, political risk, political-security risk, macro- and micro-risk with a focus on industry- or firm-specific risk. Due to its significance in this research study, risk management and mitigation and terrorism were also conceptualized. These concepts set the foundation for the chapters that follow. In Chapter Three, Statoil's history in Algeria will be contextualized and a thorough study of the history of terrorism in Algeria will be provided, focusing on the terrorist group, The Masked Brigade, led by Mokhtar Belmokhtar, and responsible for the In Amenas attack. 


\section{Chapter Three: Terrorism in Northern Africa, with Focus on the Oil and Gas Industry}

\subsection{Introduction}

The aim of this chapter is to contextualize the impact of terrorism on the oil and gas industry as well as to trace the evolution of terrorism in North Africa and more specifically in Algeria. The aim is to better understand the events leading up to the attack on In Amenas in January 2013. The chapter will firstly give an overview of the development of terrorism in Northern Africa and show how the countries in the region have been affected by it. The second section will focus on Algeria to give a more indepth understanding of the situation regarding terrorism in that country and to give an overview of the terrorist groups that have been most active in the country. Section three will look at the oil and gas industry as a target for terrorist groups. The period from Osama bin Laden's declaration of war against the West in 1996 until the present will be the main focus of this section. Section four will look at Statoil's history, with a focus on the company's international investments. This will be followed by a summary of Statoil's involvement in Algeria and a detailed review of the four-day siege at In Amenas. To understand the complexity of political-security risk mitigation and management it is important to understand the actions of terrorist groups regarding oil and gas companies. The purpose of this chapter is to give an in-depth understanding of how terrorism has affected the North African region, and Algeria in particular, as well as the global oil and gas industry in general.

\subsection{Terrorism in Northern Africa}

Terrorism is not a new threat to countries and companies in North Africa and it started long before the September 11 attacks in the US. However, before 2001 terrorism in North Africa was contained and localized. Since then, North African terrorism has become much more complex, bringing together religious ideology and criminal networks, with terrorist groups capable of operating both locally and globally (CSIS, 2010). As can be seen on the overview map below, the Maghreb region comprises Algeria, Tunisia, Libya and Morocco; its geographical position between Europe, the Middle East and Africa means that developments in the area influence millions of people all over the world, and, as international oil and gas companies expand their activities in North African countries, the threat from local terrorist groups grows. Since 2001 there have 
been numerous attacks against oil and gas companies in the Maghreb region, making it a high-risk region to invest in ${ }^{5}$.

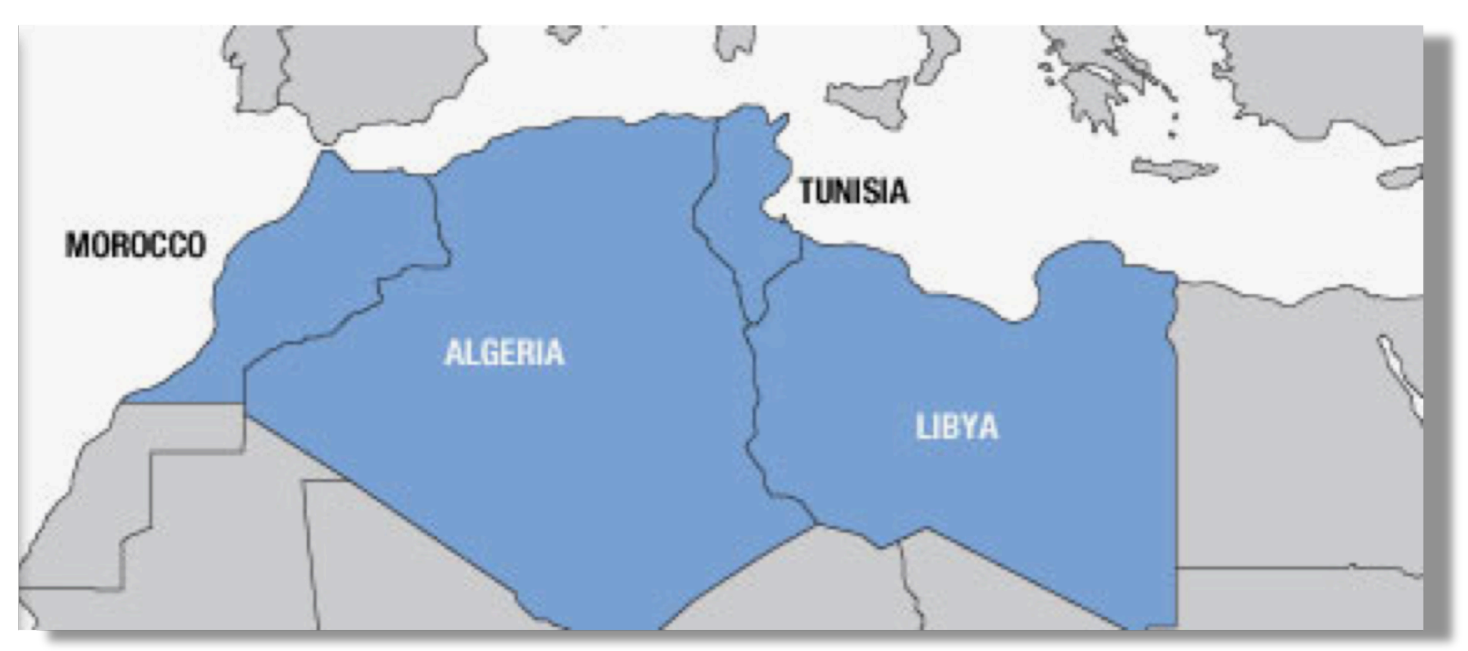

Map 3.1: Overview of the Maghreb region (Senussi \& Ziemba, 2010).

After the 9/11 attacks in New York, terrorist attacks in the Maghreb region increased by 600 per cent, leading to a United Nations Security Council (UNSC) special session in March 2013. There the UNSC warned that an "arc of instability" was spreading in Northern Africa: "if left unchecked, it could transform the continent into a breeding ground for extremists and become a launch pad for larger-scale terrorist attacks around the world" (SC/11004, 2013). This spread is especially evident in the countries bordering the Sahara and Sahel region (Alexander, 2014).

The origin of modern terrorism in the Maghreb region can in many ways be traced back to the violent anticolonial struggles that convulsed North Africa in the twentieth century, as well as North Africans returning from Afghanistan after the war against the Soviet Union in the 1980s, which continued fighting their own governments and the West. According to CSIS (2010), the combination of well-trained fighters and a very strict religious ideology produced a dangerous environment where violence and extremism thrived. The consequence of this unpredictable mix was that almost 150000 people died in the conflict between the Algerian government and Islamic insurgents in the 1990s. Algeria's experience with this brutal violence was unique, but terrorism also affected the other countries in the region.

\footnotetext{
${ }^{5}$ Appendix A: Attacks against the oil and gas industry in the Maghreb region: 2001-2011
} 
Not long after the 9/11 terrorist attack, Tunisia and Morocco were targeted in massive terrorist bombings, proving that no country in Northern Africa was safe from terrorism. During the 1990s terrorism in North Africa had almost exclusively a local focus. At the beginning of the new century the interests and activities of the different terrorist organizations expanded to involve Europe, Iraq and Afghanistan. Apart from Algerian groups, Moroccan terrorists were involved in the train bombing in Madrid in 2004, and a number of Tunisians have been deeply involved in fundraising for terrorist operations; in addition many Libyans went to Afghanistan to collaborate with AI Qaeda (CSIS, 2010).

Significant resources have found their way to North African terrorist groups, as a result of donations from wealthy al-Qaeda supporters in the Gulf States and from foreign procurement networks. At the same time, the ideology of the terrorist groups in North Africa has shifted away from the unpopular local struggle to focus on a pan-Islamic global jihadism (holy war) (Taheri, 2008). The Maghreb region's historical legacy with its anti-colonial struggle has provided a sound basis upon which different terrorist groups can build a new plan to further their struggle. The unpopular wars in Iraq and Afghanistan have given rise to a new wave of veterans who could be recruited. An example of this was the Afghan veteran, and now leader of the Masked Brigade, Mokhtar Belmokhtar. These veterans bring with them valuable skills in urban fighting and arms smuggling to the Maghreb region. The wars in Iraq and Afghanistan also gave the terrorist groups a pretext for jihad; they were easily deployed against what they saw as a Western striving for a Middle-Eastern hegemony (Pham, 2008). The invasions fuelled extremist ideology and led to the spread of terrorism in North Africa (CSIS, 2010). The two wars also led to a consolidation of many local terrorist groups in North Africa. Islamist groups in Tunisia, Morocco, Libya and Mauritania became subsumed by the larger AQIM. AQIM has taken responsibility for a number of terrorist attacks in the Maghreb and has stated as a goal the need to attack Western targets (Hansen \& Vriens, 2009). All the above-mentioned factors have led to a rise in the frequency, sophistication and spread of North African terrorism. According to Taheri (2008), terrorism in North Africa has begun to impose itself as a "new arc of terror" spreading to both Europe and North America. Many of the central figures from North African terrorist groups are Algerians or are based in Algeria. Since its independence in 1962 up to the present, the country has been the epicentre for terrorist recruitment and attacks in Northern Africa. 


\subsection{The History of Terrorism in Algeria}

For decades terrorism in Algeria has made world news. To understand the origins of the chaos and why Algeria have evolved to a hotspot for terrorist activities in the North African region, it is important to take a closer look at the country's history since independence.

After a violent liberation struggle, Algeria gained its independence from France in July 1962, bringing the National Liberation Front (FLN) to power. The FLN had been the main Algerian nationalist movement fighting for independence and in August the same year the FLN formed a new government under the leadership of Ahmed Ben Bella. During Ben Bella's term, Algeria became increasingly socialist and authoritarian, and in 1965 he was overthrown by Houari Boumediene. Boumediene continued the trend from Ben Bella's period, but was more dependent on the military. He also reduced the importance of FLN's role, from being the only legal party, to a merely symbolic one. Following the death of Boumediene in 1979, Chadli Bendjedid became President. Under the leadership of Bendjedid Arabisation was promoted in the Algerian society. They imported Muslim scholars from Egypt and Syria to 'Arabise' the French-speaking country; this spread radical Islamism and played an important role in the development of political Islamism (Botha, 2008:24). In the 1980s the oil price dropped and Algeria with its oil-dependent economy was badly hit; the country went into an economic recession, leading to social unrest. These events forced Bendjedid to introduce a multiparty party system and in 1989 a municipal election was held. After the election the Islamist party Front Islamique du Salut (FIS) became the main political force. Their goal of setting up an Islamic state in Algeria caused considerable concern among the military leaders and other sections of society, who feared becoming expiatory victims of a possible Islamic regime that was based on righteousness. In the 1991 parliamentary election the FIS was announced as the winner of the first round. The army intervened by removing Bendjedid from office and banning the FIS. The army argued that this had to be done to safeguard democracy (Martinez, 2000:1-2). The annulment of the election and the attempt by the government to destroy the FIS have been seen as the key events leading to the spread of terrorism in Algeria (Cilliers, 2003:95). The situation in Algeria in the mid-1990s was chaotic. As stated by Whittaker (2007:154), in the period between 1992 and 1996 approximately 120000 people were killed in what can be described as a terrorist insurgency, with shocking cruelty on both sides. 


\subsubsection{The Development of Radical Islam in Algeria}

The emergence of radical Islam in the years following the independence, can largely be attributed to the disillusionment of a considerable part of the population with the prolonged rule of the FLN (Cilliers, 2003:95). A number of political, socio-economic and cultural developments during FLN rule affected the development of fundamentalist and extremist organizations in Algeria. There are many reasons for this, and to mention all here would be too extensive. Accordingly, only some of the most important developments will be touched upon.

One of these developments was the continuing deterioration of the socio-economic conditions. At the end of the 1970s, unemployment rates started to rise; in 1985 and 72 per cent of the unemployed were aged 25 years or younger. This is a dramatic number, especially since that age group was estimated to comprise 65 per cent of the population (Stora, 2004:193-194). After independence, Algeria embraced a single-party system. This made it difficult for the younger generations to influence political developments in the country. President Houaru Boumedienne banned political parties and organizations that had been allowed after independence and focused more on the military elite (Shahin, 1997:114). Conditions became even worse under President Chadli Benjedid, leading to the establishment of Islamic fundamentalist and extremist groups. There was a lack of leadership, and growing dissatisfaction with the fact that many important official positions were reserved for members of the FLN; oil prices increased and there was rapid population growth. Combined with rising corruption, these are just some of factors contributing to the expansion of Islamic fundamentalism in Algeria.

\subsubsection{The Role of the Army}

The army was an important factor in the development of extremist organizations in Algeria. Since independence the army had played a key role in government, becoming part of the centre of authority in Algeria. The army was given the role of protector of the regime and it was the guardian of public order and stability (Shahin, 1997:128). This central position made it easy for the military to intervene after the municipal elections in 1989. Even before the elections, riots were taking place in a number of Algerian cities and the army was worried that this would lead to further political unrest. In response it declared a state of emergency. In reality, the army had turned Algeria into a police 
state. By placing restrictions on the development of a political culture and disallowing questioning and disagreement, the army threatened freedom of speech (Botha, 2008:26). After the riots in 1988 President Bendjedid decided to establish a multi-party system in the hope of preventing further unrest, but this did not go as planned and the army removed the government in 1992 (Martinez, 2000:2).

A number of important organizations have been involved in terrorism in Algeria: what follows is an outline of the most influential groupings.

\subsubsection{The Return of the Mujahideen}

After almost a decade fighting the Mujahideen in Afghanistan, the Soviet Union withdrew in 1989, leading to the return of veterans to Northern Africa. Algeria was one of the countries that was most affected. The spread of radical fundamentalism was initially financed by Middle Eastern countries like Saudi Arabia. There was then a shift to private radical financiers, such as Osama bin Laden. During the final years of the war in Afghanistan, many hardened war veterans returned home. Estimates of their number vary from 600 to 3,000 . Upon their return to Algeria they formed the core of the terrorist groups that would promote violence (Cilliers, 2010; Martinez, 2006). When they returned they wore, in contrast to the rest of the population, Afghan-style clothing; with their long beards and turbans they became known as 'les Afghanis'. (Botha, 2008:32). Previously the extremist groups in Algeria had focused more on internal issues, after the return of the veterans these organizations reoriented their focus. Botha (2008), argues against the importance of the war veterans as a factor explaining the trouble in Algeria. She argues that although the Mujahideen veterans played a key role in the formation of important radical groups such as the Groupe Islamicque Armé (GIA) and later Groupe Salafiste pour la Prédication et le Combat (GSPC), there already existed favourable conditions for the development of radical Islamic movements in Algeria. Islam had been a source of identity long before the Afghan veterans returned; it was a key feature of the 132-year-long war against colonial subjugation. The fight against France was not only carried out in the name of Algeria, but also in the name of Islam (Botha, 2008:23). This could clearly be seen in the already-existing group, Front islamique du Salut (FIS). 


\subsubsection{Group Islamicque Armé}

The GIA was probably the most brutal of the extremist groups in Algeria. It was established in 1993 and was heavily influenced by the Algerian Afghans. After the army seized power, the Algerian Afghans were not interested in elections and stated that the use of force was the only way to gain power and to set up an Islamic state (Cilliers, 2003:96). While the other groups in Algeria saw victory as establishing an Islamic state of Algeria, GIA wanted to implement a Islamic state through the transformation of society by embracing fundamentalism (Gray \& Stockham, 2008:92). The GIA was different from other extremist groups because of its focus on targeting civilians. They attacked government officials, journalists, intellectual's, feminists, French-speaking people and other groups which they saw as contaminated by Western values. These were people who had abandoned Islam and therefore it was allowed to kill them (Steinberg \& Werenfels, 2007:408). In September 1993 the GIA began to attack foreign correspondents and foreigners living in Algeria, and by 1997 over 115 had been killed (though the actual number might be much higher due to very inadequate the reporting) (Whittaker, 2007:159). The GIA's bloody attacks on civilians led to a dwindling of support among the Algerians. Constant rumours that the organization was manipulated by Algerian intelligence agencies also brought the group into disrepute (Steinberg \& Werenfels, 2007:408). The killing of Muslims was heavily criticized in the Muslim world. One of the consequences was that the former supporters in extremist circles in London decided to end their propaganda activities on behalf of the GIA. The combination of dwindling local support from Algerians and reduced international support from jihadist movements, led by AI-Qaeda, made the GIA to a large extent irrelevant; it conducted its last international attack in 1996. As a result of this a number of smaller factions split off from GIA. One of the GIA's former regional commanders, Hassan Hattab, recognized the errors made by the GIA and, together with a number of Afghan veterans, created Groupe Salafiste pour la Prédication et le Combat (GSPC) in 1998 (Gray \& Stockham, 2008:92). This was to become one of the strongest groups in Algeria.

\subsubsection{The Salafist Group for Preaching and Combat}

GSPC was founded by a group of Algerians who were irritated that GIA's brutal strategy had ruined the good name of both the Algerian militants and the cause they were fighting for. According to a former GSPC member, Mohamed Berraced, Osama bin Laden were pushing for Hattab to break away from GIA to form a group with tactics and target selection that were less extreme. Al Qaeda stopped their support of GIA in 1996 
(Botha, 2008:39). One of the main goals of the founding members was to restore international support for the Algerian insurgency, making it possible for them to work together with international Islamist networks (Hunt, 2007:5). Of the new groups established after the fall of the GIA, the GSPC was seen as the strongest; it managed to get some support from the Algerian population due to their focused attacks on security forces and state institutions. According to Steinberg \& Werenfels (2007), the GSPC was as much a nationalist organization as an Islamist organization; even though the GSPC was cooperating with other international terrorist organizations, its main aim was to pursue a nationalist Algerian agenda. Shortly after being established, the GSPC took control of the GIA's former support and logistical contacts in Europe; this explains how they were able to become so powerful so quickly (Steinberg \& Werenfels, 2007:408). The GSPC in Algeria split into two main groups, one operating in the north, while the other one was operating in the Sahara desert in south of Algeria. The southern group, until 2007 led by Mokhtar Belmokthar, was able to take advantage of the great number of criminal opportunities in the area. According to Hunt (2007:6), he particularly focused on smuggling, from which he got one of his nicknames, Mr. Marlboro.

By the late 1990s and early 2000, although the GSPC had become the most influential armed group in Algeria, they did not manage to destabilize the country, which was one of their main goals. They were able to get support from other militant Islamists, but their support among the Algerian population were dwindling because of a number of massacres of civilians in the mid-1990s (Steinberg \& Werenfels, 2007). This made people believe that armed struggle against the government was not the best way to bring change to Algeria. The GSPC was forced onto the defensive by the Algerian security forces, which managed to confine GSPC activities to a region east and southeast of the Algerian capital, Algiers. The pressure on the GSPC increased substantially after 11 September 2001, when the US identified Algeria as a significant country for al-Qaeda activities. During the 2000s GSPC suffered from internal power struggles and from a limited ability to carry out attacks. As stated by Steinberg and Werenfels (2007:409), this helps to explain why they chose to enter into closer cooperation with Al-Qaeda. 


\subsubsection{Al-Qaeda in the Islamic Maghreb}

In 2005 and 2006 the main focus for the GSPC was to send fighters to the war in Iraq as part of its merger with al-Qaeda. The group had already sworn allegiance to al-Qaeda in 2003, but the al-Qaeda leadership in Pakistan was hesitant to acknowledge GSPC as part of its framework in northern Africa. The al-Qaeda leadership had a number of concerns. First, the reconciliation movement in Algeria had been successful in getting great numbers of former GSPC fighters to surrender. From a peak of 4000 members in 2002, the GSPC had dropped to under 500 members in 2006. Another concern was that they were questioning the GSPC's commitment to a global agenda on account of their prioritization of domestic issues over international concerns (Gray \& Stockham, 2008:94). The GSPC addressed these concerns by sending fighters to Iraq. They also expanded their activities into the Sahara-Sahel region, where the smuggling of contraband and human trafficking made it possible to send fighters to Iraq; at the same time this improved the organization's international profile (Harmon, 2010:16). In 2003 the GSPC swore allegiance to al-Qaeda and in 2004 they announced their international focus by declaring war against all Western foreigners on Algerian soil. In 2006 the group carried out one of its first attacks on foreigners when they attacked the international oil and gas joint venture company, Brown \& Root Condor. One person died and 9 were injured when two busses carrying oil workers were attacked near Algiers (BBC, 2006). In January 2007 the GSPC became formally integrated into al-Qaeda and changed its name to al-Qaeda in the Islamic Maghreb (AQIM) (Harmon, 2010:16). After the merger with al-Qaeda, AQIM began a new offensive to please its new patrons. This included a roadside attack on a bus carrying Russian and Ukrainian workers on behalf of a Russian pipeline construction company some $130 \mathrm{~km}$ southwest of Algiers. Four workers were killed and several injured (Sedarat, 2007). This was done to show AQIM's commitment and their resolve to hit foreign targets.

After the terrorist attack on In Amenas in 2013 it was the former GSPC and AQIM commander, Mokhtar Belmokhtar, who claimed responsibility. For almost a decade he had been having a troubled relationship with GSPC/AQIM and he had been building a name for himself outside AQIM (Profile: Mokhtar Belmokhtar, 2013). 


\subsubsection{Mokhtar Belmokhtar and the Lead-up to the In Amenas Attack} Information about Mokhtar Belmokhtar has to be used with caution. Not much information is available about Belmokhtar or his newest terrorist group, the Masked Brigade. Much of the available information has been derived from anonymous intelligence sources and from interviews with Belmokhtar himself. Nonetheless, it is possible to get some sort of an account of his work over the last two decades, which has been strongly influenced by the transformation of terrorism in Algeria.

After the In Amenas attack Mokhtar Belmokhtar again proved himself to be one of the leading jihadist personalities operating in the Sahara. He has been an important actor in the GIA, the GSPC and in AQIM: with two decades of involvement in jihadist activities he has become a important force in the Maghreb region (Black, 2009:8). As regional leader of the GSPC in the south of Algeria he played a vital role in supplying the organization's operations in the north with weapons. 2003 was a turning point for Belmokhtar when he failed to become leader of the GSPC. After this failure he distanced himself from the GSPC, focusing more on consolidating his control in southern Algeria and improving his relationship with local groups. In 2006, during GSPC's merger with alQaeda, Belmokhtar again asked to move up the ranks, but he was again denied. According to Callimachi (2013), his increasing frustration over not being valued caused him to drift even further south, where he established smuggling routes and recruited loyal fighters calling themselves the Masked Brigade.

There is much uncertainty with regard to the establishment of the Masked Brigade. According to Black (2009) the group was founded in the early 2000s. Aronson (2014) and Callimachi (2013), on the other side argue that the group was founded sometime after 2007, while others again argue that the group was founded as late as at the end of 2012 (Erlanger \& Nossiter, 2013). Nonetheless, as argued by Black (2009:10), it is important to note that Belmokhtar and his brigade, despite their increasing detachment from AQIM, were for a long time important suppliers to the organization.

In a letter dated October 2012 AQIM criticized Belmokhtar for his lack of action. They claimed that he had failed to carry out any spectacular attacks, despite the opportunities in the region. In the same month he left AQIM (Callimachi, 2013). It has not been 
established whether he left voluntarily or if he was suspended (Erlanger \& Nossiter, 2013). After the break with AQIM, Belmokhtar and the Masked Brigade allied themselves with the Movement for Oneness and Jihad in West Africa (MUJAO), another Islamic group, and set up base in the north-eastern city of Gao in Mali (Erlanger \& Nossiter, 2013). Even though he had left AQIM, his group still answered to al-Qaeda's senior leadership (Joscelyn \& Roggio, 2013). In a public statement in December 2012 he announced that he was planning to attack Western interests (Roggio, 2013), and just weeks later he launched what was one of the deadliest attacks against an international oil and gas facility.

\subsection{Terrorism in the Oil and Gas industry}

Oil and gas facilities have always been a favoured target for terrorist groups. The attacks on pipelines, refineries, tankers, oilfields and facilities normally have two goals: to weaken the stability in the country they are operating in and to undermine the economies of foreign countries with interests in the country. During the last decade alone there have been numerous attacks against oil and gas targets, mainly in Africa, Latin America, the Middle East and Africa ${ }^{6}$. Luft and Korin (2003) argue that these attacks did not initially receive much attention, thus they were put into the broad category of industry risk.

Security for the world's oil and gas supply is to a large extent affected by political stability and, as seen in Tables 1 and 2 below, most of the oil and gas reserves are found in regions known for being politically unstable; this applies particularly to the Middle East, Eastern Europe, Africa and South and Central America. Oil and gas production in these areas can be affected by political turmoil, armed conflict and terrorism. In previous times, when the gap between supply and demand was bigger, a disruption in production did not have the same effect as it was easier to find an alternative supplier. Today, because of the growing consumption of oil and gas, this gap has become much smaller. A minor disruption in production may have serious negative consequences for the world economy, and, as stated in Johnston (2008:1), terrorist groups all over the world have taken advantage of this and are today attacking oil and gas infrastructure to attain their goals.

\footnotetext{
${ }^{6}$ Appendix B: Terror attacks against the oil and gas industry in Africa, Latin America and Middle East: $2001-2011$
} 
Table 3.1: Distribution of gas reserves 2013

\begin{tabular}{|l|l|}
\hline Middle East & $48,4 \%$ \\
\hline South and Central America & $19,7 \%$ \\
\hline North America & $13,2 \%$ \\
\hline Africa & $7,8 \%$ \\
\hline Eastern Europe & $7,4 \%$ \\
\hline Asia & $2,5 \%$ \\
\hline Western Europe & $0,7 \%$ \\
\hline
\end{tabular}

(Source: BP, 2013).

Table 3.2: Distribution of oil reserves 2013

\begin{tabular}{|l|l|}
\hline Middle East & $43 \%$ \\
\hline Eastern Europe & $29,2 \%$ \\
\hline Asia & $8,2 \%$ \\
\hline Africa & $7,7 \%$ \\
\hline North America & $5,8 \%$ \\
\hline South and Central America & $4,1 \%$ \\
\hline Western Europe & $1,8 \%$ \\
\hline
\end{tabular}

(Soruce: BP, 2013).

\subsubsection{The Threat from al-Qaeda}

In 1996 Osama Bin Laden made a public declaration of war against the West and he pointed out targets that were legitimate to attack. These were targets that would not affect the economic and social structures in Islamic states. He specifically stated that oil and gas infrastructure in the Middle East was not to be attacked, due to its strategic importance as a revenue source which would be used to build the pan-Islamic super state that Bin Laden planned to create. In the declaration he only allowed for attacks against Western workers working in the oil and gas industry in the Middle East. The declaration did not prohibit attacks against transport infrastructure used to carry oil and gas to Western countries (Johnston, 2008:5). An example of such an attack was the bombing of the French oil tanker MV Limburg off the coast of Yemen in 2002; it was carrying almost 400000 barrels of crude oil. The bombing resulted in one dead, with twelve injured, and 90000 barrels of crude oil leaked out into the Gulf of Aden (Sutton, 2011). After the attack Al Qaeda issued a statement saying: "by hitting the oil tanker in Yemen, the mujihadeen hit the secret line, the provision line and the feeding to the 
artery of the life of the crusader's nation" (Lorenz, 2007:19). This declaration clearly reaffirms the legitimacy of attacks aimed at oil and gas transport facilities. It also clearly shows that al-Qaeda sees Western consumption of Middle East oil as pillage by the West. In Saudi Arabia several attacks were aimed at foreign workers. One of these was the attack on a petrochemical plant in Yanbu on May 12004 , killing five foreigner workers and wounding three others (Macfarquhar, 2004). In the same month, on May 29 2004, an oil industry compound in Khobar was attacked, leading to the deaths of 22 foreign workers. According to reports from the BBC (2004), the terrorists were apparently trying to separate out the Western workers; they released five Lebanese workers just hours after the attack.

\subsubsection{9/11 and the New Focus on the Oil and Gas Industry}

However, the period where only Western workers were seen as legitimate targets was about to end. After the September 11 attack, assaults against petroleum facilities gained higher priority. Terrorist organizations started to identify oil and gas installations as targets that would have a major impact on the oil-dependent economies of the West. With the heightened security around transportation networks, government installations and military bases in Western and oil-producing countries, Al Qaeda issued a decree legitimizing attacks on all oil and gas facilities supplying the West (Johnston, 2008:6). In March 2004 one of the leading figures in Al Qaeda at the time (now deceased), Abdul Aiz al-Moqrin, published a document entitled "The Targets inside Cities" on several Jihadist websites. In the document al-Moqrin gave instructions on targeting to the group's members and to other affiliated groups. In the document al-Moqrin focuses on the oil sector: pipelines, wells, refineries and other Western investments in the oil and gas industry were included as acceptable targets. These types of attack would strike an economic blow at the enemies of al-Qaeda and their allies (Toft, Duero \& Bieliauskas, 2010:4417). This statement contradicts Bin Laden's declaration of 1996 in the sense that it argues that these types of attacks did not undermine Muslim wealth since the oil at the time was not the property of the Muslim public community. However, as reported by Toft et al. (2010:4417), al-Moqrin states that members should not attack without permission from the top leaders in Al-Qaeda; they would decide on the type of targets to be attacked on a case-to-case basis. 


\subsubsection{The Importance of Oil and Gas}

Another document was also released in 2004, by the known jihadist Abu Bakir Naji and was named "The Management of Savagery: The Most Critical Stage Through Which the Umma Will Pass" (Naji, 2004). This document outlines a doctrine that sketches the strategies that jihadist movements should employ if they are to rebuild an Islamic state; these strategies should be applied to tackle organizational problems that may occur. $\mathrm{He}$ also argues for the importance of oil and gas installations as targets for the Al-Qaeda network. The only way to defeat the Western states is by attacking the core of their economies, which are based on oil and gas (Naji, 2004:47). Or, as stated by a Jihadist website, "The killing of 10 American soldiers is nothing compared to the impact of the rise in oil prices on America and the disruption that it causes in the international economy" (Giroux \& Hilpert, 2009). Naji's argument for carrying out attacks on oil and gas installations is that it is an useful long-term strategy for weakening the financial and military capabilities of the West. In line with Al-Moqrin's statement, he also points out that in spite of the negative economic consequences, these will only last for a short time following the attacks on oil and gas facilities; however, the attacks are justified because the wealth gained from oil is distributed unequally in favour of Western countries and cooperating Arabic governments. At the same time, Naji (2004) is clear on what types of oil and gas facilities not to be attacked. Oil wells are not to be attacked since these are needed to secure the wealth of the Muslim people after the Jihadists have taken control over 'their territories' and defeated the West.

\subsubsection{Terrorist Should only Attack Targets where the Benefit Outweighs the Cost} A third document, released in June 2004, clearly supports al-Qaeda's stand on operations against oil and gas installations. The document was written by a cleric named Ab-al-Aziz bin Rashid al-Anzi and named "The Laws of Targeting Petroleum-Related Interests and a Review of the Laws Pertaining to Economic Jihad" (Toft, et al., 2010). As with the other two documents, it focuses on the oil and gas industry as an attractive target for terrorist organizations and argues that oil and gas installations that are not controlled by Muslims are legitimate targets. In the document al-Anzi emphasizes that an attack only should be conducted if the benefits of interrupting the flow of oil and gas do not outweigh the costs. When weighing the costs against the benefits he argues that the costs of attacking oil wells are too high. These types of attack can cause severe 
environmental damage, and a loss of wealth that is impossible to recover from; they also result in negative publicity in the Arabic media, which in the long run can turn the general population against jihadist movements. When it comes to other targets of attacks, like oil tankers, pipelines and refineries, al-Anzi argues that the benefits outweigh the costs. These are targets that are easy to attack and at the same time have strategic value (Toft, et al., 2010:4418), while the environmental damage is seen as small and acceptable and the possible loss of wealth loss is seen as tolerable.

As mentioned, after Bin Laden made his famous declaration of war against the West in 1996, there has been an increase in attacks on oil and gas installations. These have risen from a little less than 200 in the period between 1980 and 1990 to almost 400 in the period between 2000 and 2011, according to the Energy Infrastructure Attack Database (EIAD) (cited in Giroux \& Gilpin, 2013).

\subsubsection{How Terrorism is Affecting the Oil and Gas Industry Around the World}

One of the countries that have felt the impact of this upsurge in terrorist activity is Saudi Arabia. Saudi Arabia is vulnerable to terrorist attacks due to the amount of oil and gas produced in the country, combined with the frequent occurrence of terrorist organizations in the region. Saudi Arabia has experienced a number of terrorist attacks and attempts, but it is not the only oil and gas producing country that is in danger of being exposed to terrorism. A number of countries outside the Middle East, primarily in the former Soviet Union, Africa and South Asia are also vulnerable to terrorist attacks (Luft \& Korin, 2003). A common feature of many of these groups is that they are affiliated to al-Qaeda and often follow the recommendations given by the central leadership of al-Qaeda. Al-Qaeda's focus on the oil and gas industry affects targets around the globe as will be explained below.

\subsubsection{The Former Soviet States}

A number of the former Soviet states sitting on large oil reserves are facing a rise in the threat of terrorism from organizations operating from Central Asia and the Caucasus. Among these groups are Hizb ut-Tahrir al-Islam, the Islamic Movement of Uzbekistan, the Islamic party of Eastern Turkestan, together with groups of Uighur and Chechen separatists. Of these groups Hizb ut-Tahrir al-Islam is seen as one of the more dangerous. It is located in Tajikistan, Uzbekistan, Kyrgyzstan and Kazakhstan, which 
have large oil reserves. According to Luft and Korin (2003), this group is trying to seize power and introduce a Sharia-based Caliphate, which will focus on continuing the holy war against the West.

\subsubsection{South Asia}

South Asia, with its growing demand for oil, has come to be a new terrorist target. Al Qaeda's main man in the region and leader of the terrorist group Jema'ah Islamiyah, Riduan Isamuddin, also known as Hambali, was arrested in 2003 after being accused of the nightclub bombing in Bali in 2002. He is also known for planning a number of attacks against oil depots in the Philippines and against the American oil company, Caltex Oil, in Singapore (Abuza, 2003:154). As can be seen in Luft and Korin (2003) terrorist groups in both these places have identified oil and gas installations as highly vulnerable targets that can be attacked to strike a severe blow to the regimes which these groups are fighting.

\subsubsection{Africa}

Africa is home to a number of oil- and gas-producing countries that face a terrorist threat. Nigeria, which has the largest reserves of oil in Africa, has been called the "the next hotbed of Islamic radicalism" (Marshall, 2002), and at the current moment the terrorist organization, the Congregation of the People of Tradition of Proselytism and Jihad, also known as Boko Haram, is advancing in the country. In a video released 14 February 2014 the group's leader, Abubakar Shekau, warned that Boko Haram was planning to bomb oil refineries in the Niger Delta, Nigeria's most important oil-producing region. Local groups in the Niger Delta are also causing problems for the oil industry. In 2005, one of the main groups, Movement for the Emancipation of The Niger Delta (MEND), launched a large-scale offensive, targeting the Nigerian government and the international oil companies operating in the Niger Delta (Giroux \& Hilpert, 2009). The bombing of oil facilities and kidnappings cut Nigeria's oil exports by more than 28 per cent between 2006 and 2009. MEND stated in January 2014 that, "at the right time, we will reduce Nigerian oil production to zero by 2015 and drive off our land, all thieving oil companies" (Bala-Gbogbo, 2014). This shows that foreign oil companies face a serious security risk in Nigeria. 
As seen here, oil and gas facilities and personnel all over the world are attractive targets for terrorism. The Norwegian oil and gas company Statoil is one of the companies that have experienced this: they lost five workers during the In Amenas attack. The next section will give a brief overview of Statoil and its international operations.

\subsection{The History of Statoil}

The In Amenas gas facility is a joint venture between Sonatrach, BP and Statoil. In this research study, Statoil's political security-risk mitigation and management is analyzed. Some background information about the company is necessary. The Norwegian State Oil Company, also known as Statoil, was formed in 1972 as a company wholly owned by the Norwegian state; it was the state's instrument for the development of the oil and gas industry on the Norwegian continental shelf. In 2001, Statoil was listed on the Oslo and New York stock exchanges and is today one of world's largest sellers of crude oil and the second-largest supplier of gas to the European countries. As of 2013, Statoil is involved in operations in 33 countries and has more than 23400 employees (Statoil, 2014).

At the end of the 1980s Statoil considered it highly likely that they would not find a new giant oilfield, as they did during the 1970s, on the Norwegian continental shelf. If Statoil was to continue as a profitable oil company, it had to expand internationally (Ryggvik, 2014). In response to this, Statoil announced in 1990 that they had entered into strategic alliance with BP. BP was a much bigger company and had the international experience that Statoil lacked. On the other hand BP saw an alliance with Statoil as a step towards improving their reputation, which in many countries was rather poor due to the fact that they had been used as a tool of the British Empire. The two companies would cooperate in exploration and production in different regions around the globe. Initially the focus was on Vietnam, Aserbaisjan, Nigeria and Angola where BP had a two-thirds share, while Statoil had one-third. In 1998 BP bought the American oil company, Amoco, and pulled out of the alliance. In 2007 Statoil merged with Hydro's oil and gas division to enable it to compete with large international companies such as ExxonMobil, Chevron-Texaco and Conoco-Phillips. The merger with Hydro did not produce an immediate breakthrough internationally, but in countries where both companies had been previously involved, such as Libya, Russia, Brazil and Angola, their position was 
strengthened (Ryggvik, 2014). Throughout the late 2000s Statoil expanded its international activities and is today present in a number of the most important oil and gas regions in the world. Its most important investments are in Algeria, Libya, Angola, Nigeria, Russia, Azerbaijan, the US, the UK and Venezuela. In 2013 Statoil's international activities amounted to 37 percent of Statoil's equity production (Statoil, 2014). In 2003 Statoil decided to enter Algeria; this become the company's first onshore operation (Statoil, 2013a), and it suited Statoil's international strategy.

\subsubsection{Statoil in Algeria}

Algeria has for a long period been one of the most important players in the international gas market and is currently the second-largest provider of gas to the European market (Ernst \& Young, 2012). Statoil's goal of becoming an international player in the gas market was in keeping with Algeria's large gas reserves. Statoil first started to consider investments in Algeria in 2002.

At that time Statoil's international investments were small: only four per cent of the workforce worked in the international division, which counted for only eight percent of Statoil's total production. Statoil's interests outside the Norwegian continental shelf at the time only involved a marginal field in China (Statoil, 2013a:34). In 2003 Statoil paid \$840 million for a share in the two development projects in Algeria's gas field's, these were In Amenas and In Salah, which can be located on the map below. The first gas exports from In Salah started in 2004, while the In Amenas project started exporting in 2006 (Statoil, 2013b). In Amenas is one of the biggest gas developments in Algeria. It is located $50 \mathrm{~km}$ from the Libyan border and almost 1,300 km from the Algerian capital of Algiers. 


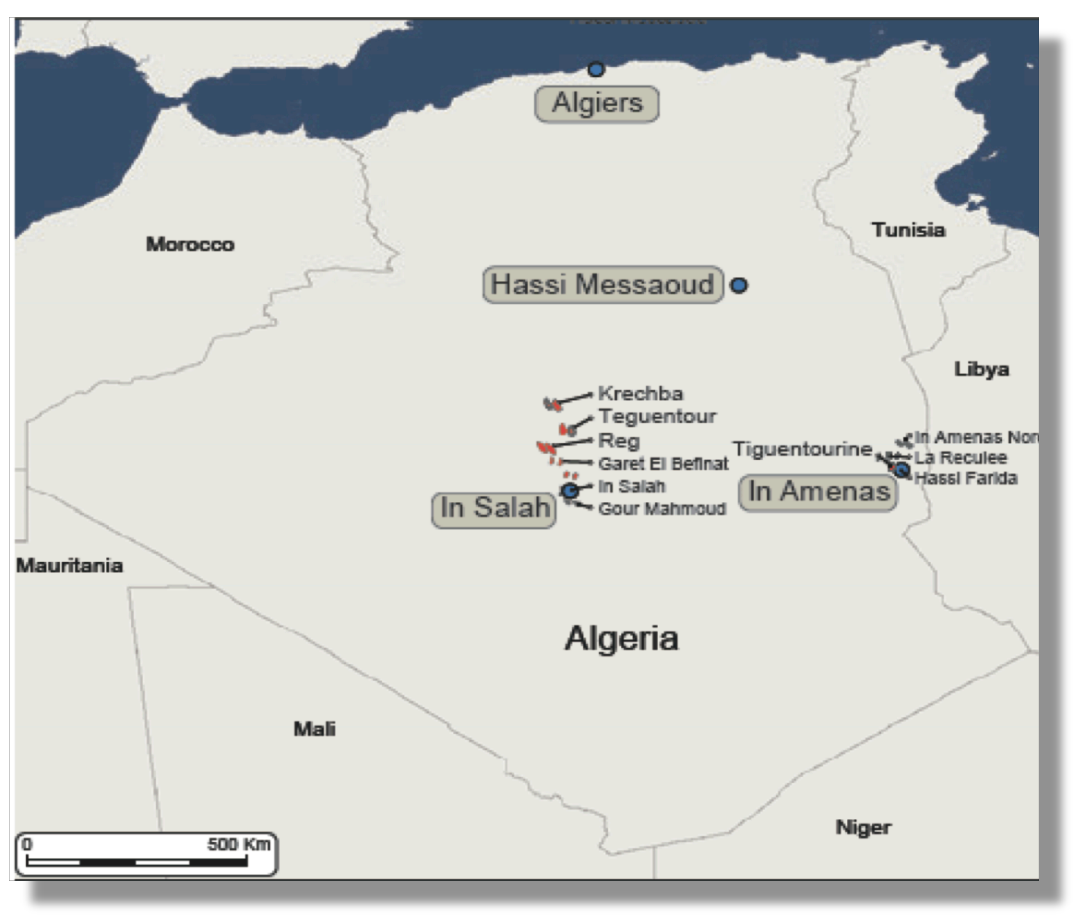

Map 3.2: Algeria's main gas fields (Statoil, 2013a)

Joining BP was seen as a major step for Statoil. Operating the facilities in Algeria would give Statoil valuable experience, which was ideal for its international growth ambitions. The In Amenas project consists of four gas fields, and the processing facilities in Tiguentourine. The contract area covers 2,750 sq. km., an area the size of Luxembourg. This is operated as a joint venture between Statoil, BP and the Algerian national oil company, Sonatrach (Ree, 2013). When investing in Algeria it is normal to enter into a joint venture with Sonatrach, which will hold at least 51 percent of the interest in all new projects (Ernst \& Young, 2012). BP have been involved in the Algerian oil and gas business since the mid-1950s and signed the In Amenas project contract in 1998. The In Amenas report (Statoil, 2013a:35) reveals that in 2003 Statoil bought half of BP's share in the In Amenas project. Through the joint operation the In Amenas project was equally shared, with a proportionate allocation of the most important management positions between Statoil and BP.

When investing in Algeria, foreign companies are expected to invest in social development programmes and infrastructure. Statoil has, together with the United Nations Development Found (UNDP), supported an education project for Algerian women (Statoil, 2013b). Another project is a clean water production and purification facility that provides the households of In Amenas with water. Statoil has also invested in a 3.5-kilometer-long pipeline distributing water to the nearby town of Hassi Ghanem 
(About the In Salah gas joint venture, 2010). Before investing in Algeria, Statoil was aware of the security risk involved in such a project (Statoil, 2013a:36), but by having a local partner in Sonatrach, a global partner in BP and the Algerian army stationed close by, Statoil felt that the security risk of investing in the In Amenas project was acceptable.

\subsection{The Attack on In Amenas}

The terrorist attack against the In Amenas facility in January 2013 lasted for four days and became one of the most serious attacks against an oil and gas facility in the industry's history. The facility employed over 800 people, and of these more than 130 were foreigners. When the Algerian army took control of the area on the fourth day, forty people from ten different nations had lost their lives (Unpacking Algeria's hostage crisis, 2013). What will follow is a brief overview of what happened during the terrorist siege of In Amenas. An overview map of the site as well as a map of the production are provided to give better visualization of the facility and the surrounding area, making it easier to understand what happened during the four days. 


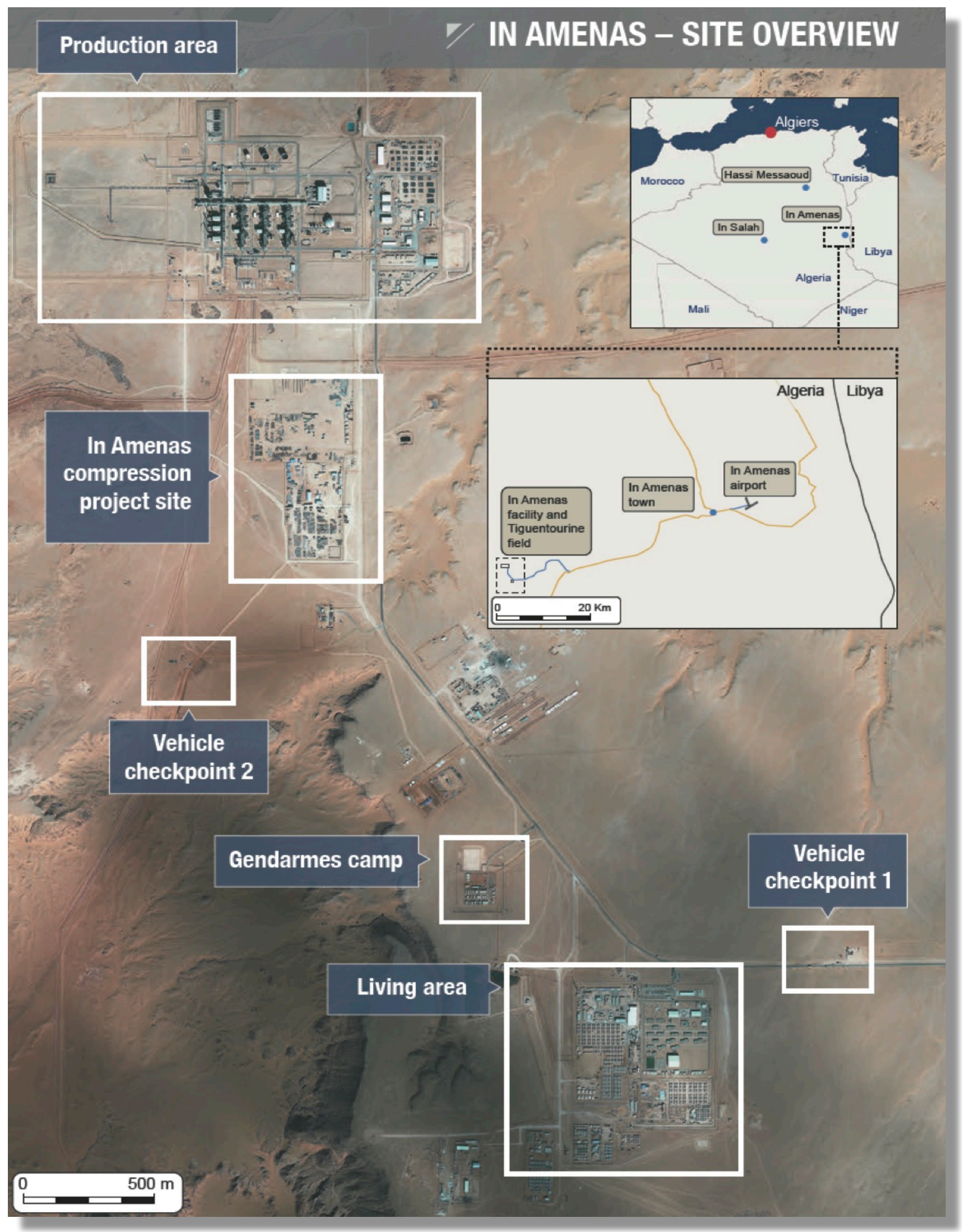

Map 3.3: In Amenas site overview (Statoil, 2013a). 


\subsubsection{Day 1}

On the morning of Wednesday 16 January 2013, at approximately 05.30, a bus carrying workers left the living area. Some of the workers were going to the city of In Amenas while others were going to the airport. Three vehicles from the gendarme escorted the bus together with a security liaison vehicle. Close to checkpoint one, indicated on map 3.3 above, the convoy came under heavy fire from several attackers. At the same time a number of vehicles passed the bus heading for the living and production area. The gendarme returned fire and were able to radio the guards in the living area; the guards sounded the alarm, alerting the workers to the attack. A security guard and a security liaison were killed, while a Statoil employee was injured. According to Howden (2013), a soldier was able to break open one of the bus's windows during the shootout, making it possible for the passengers, including the injured Statoil employee, to escape to checkpoint one, where they were rescued by the Algerian army.

Next, heavily armed militants in several vehicles crashed through the gate of the living area where workers were on their way to breakfast and several of the workers were shot and injured. The militants immediately started to search for foreigners. The Algerian workers were told that they were not the targets and that they could take their belongings and leave. However, foreigners were found hiding among the Algerians when they were exiting, and this led to everyone being escorted back into the living area. The militants were especially looking for French, American and English nationals (Andreassen, 2013). Foreigners who were found were gathered up and many had explosives attached to their necks and waists. The terrorists also planted booby-traps and mines around the living area as a defence against an anticipated assault from the Algerian army (Howden, 2013).

At the same time as the living area was attacked, another group of militants advanced to the production area where a number of workers, including four Statoil employees, were gathered. The workers were rounded up and put on a pickup which took them to the central control room, indicated as the main IBO office on map 3.4 below. According to Nossiter \& Kulish (2013), the terrorists forced one of the hostages to restart the plant, which during the attack on the living area had been shut down as a result of a bullet hitting a high voltage transformer. It was not possible for the employee to restart the 
plant by himself; when another hostage also failed to restart the plant, the terrorists gave up and moved all the hostages over to the gas processing trains.

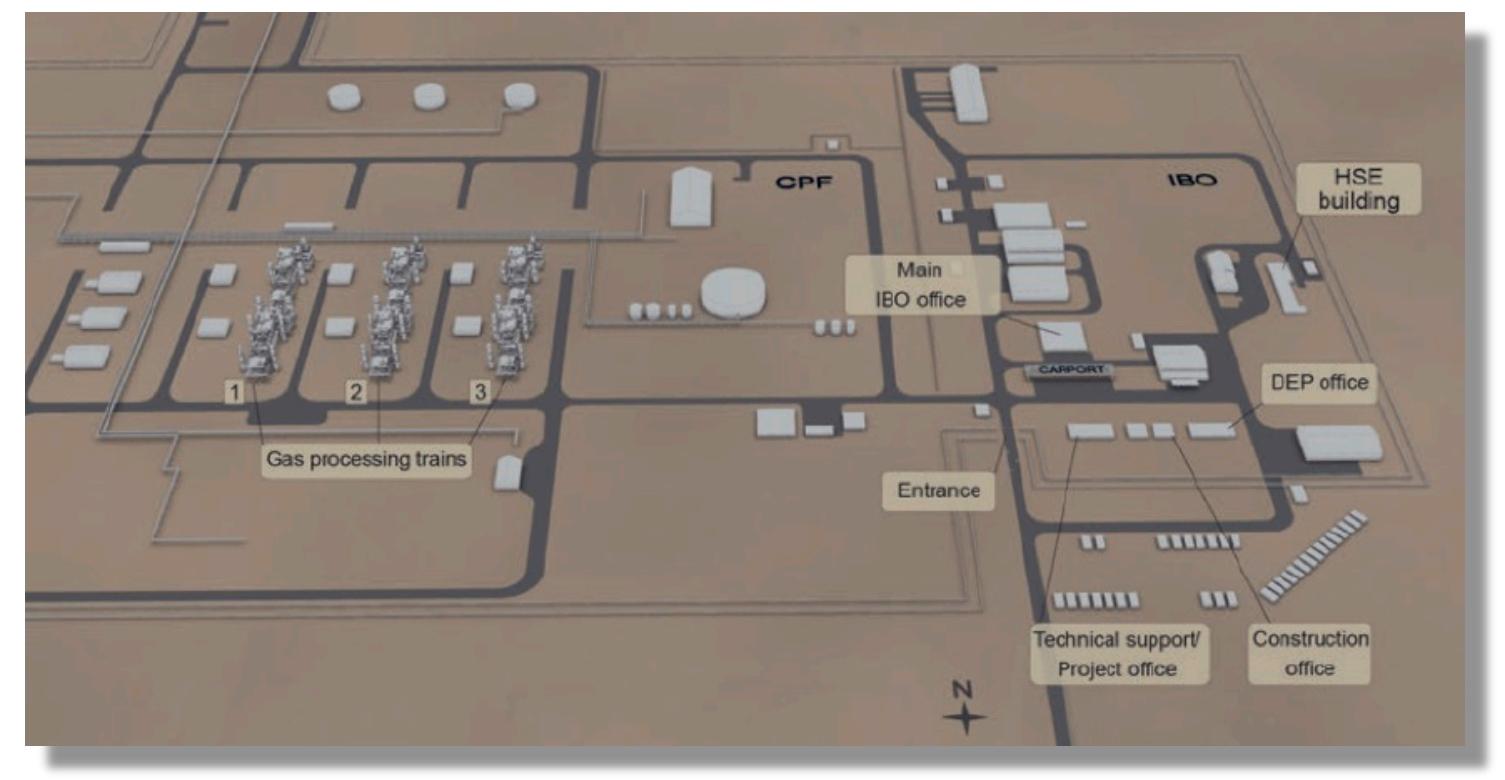

Map 3.4: Overview of the production area (Statoil, 2013a).

Through the entire first day of the siege there were extensive negotiations between the terrorists, the Algerian government and the joint venture. According to a video released by Belmokhtar on January 17, two days before the siege ended, the attack was a response to the Western intervention in Mali on January 11. A number of scholars have doubted this. French troops arrived in Mali just five days before the In Amenas attack. An attack this complex would have required months of planning. The French intervention was probably used as a justification for an attack that would have happened anyway (Jenkins, 2013). In the video Belmokhtar also demanded the release of Omar Abdel Rahman and Aafia Siddiqui, who had both been imprisoned in the US on charges of terrorism. Their final request was for an aeroplane (Roggio, 2013) to enable the terrorists and the hostages to be transported to Mali.

\subsubsection{Day 2}

In the morning of the second day a military helicopter fired into the living area, wounding the terrorist leader, Taher Bechneb. This prompted hundreds of the Algerian hostages to run for the gate in an attempt to escape, forcing the helicopter to withdraw. The terrorists 
gathered the foreign workers as a human shield and began to move to the hostages to the production area (Nossiter \& Kulish, 2013). In the afternoon the hostages were strapped with explosives and loaded into vehicles positioned next to the doors, ready to be used as human shields. When the vehicles left the gates of the living area they were fired upon by Algerian military helicopters and personnel on the ground. There are different accounts as to how many vehicles left the living area, but according to several sources six vehicles left the gate. On the way to the production area three of the cars exploded, two of the vehicles crashed, and one was hit by small arms fire from the army; it stopped outside the gendarme camp. Of the 26 hostages who were in the vehicles, only 10 survived. Two of the hostages walked to the production facility, but were killed by a terrorist who was still there (Howden, 2013). At the production area eight foreign workers from Norway, Romania and Britain decided to escape (Kulish, 2013); in the middle of the night they managed to get over the six-foot-high fence and head out into the desert, where after 15 hours with supplies running low they were picked up by the gendarme.

\subsubsection{Day 3}

On the third day, January 18, the army surrounded the production area and prepared to save the last hostages. There is little information on what happened at the facility on the third day because very few of the hostages survived (Chrisafis et al., 2013). In the afternoon an explosion occurred in the production facility. After the incident the wreckage of a car was found at the centre of the explosion outside gas processing train 3 , together with five dead hostages, three of whom were Statoil employees (Statoil, 2013a:32).

\subsubsection{Day 4}

On Saturday morning, January 19 , the army launched its final assault on the production area, killing 11 terrorists, and saving the remaining hostages; they declared the military operation over (Chrisafis et al., 2013). Of the 32 terrorists, 29 were killed (Ahmed, 2013), while the three remaining terrorists were arrested by the gendarme. 
Here a detailed summery of the attack have been presented. In Chapter Four, the attack will be analyzed in more detail, looking at the political-security risk measures before and after the attack.

\subsection{Conclusion}

The purpose of chapter three has been to contextualize terrorism in the oil and gas industry and describe the development of terrorism in North Africa and Algeria.

To enable an understanding of the conditions under which Statoil was operating in Algeria, this chapter analyzed the origins of terrorism in Algeria and in the larger Northern African region. The development of key terrorist groups in Algeria has also been examined to provide an understanding of the events leading up to the In Amenas attack. This chapter has also provided an insight into Statoil's history and the conduct of its international business. This helps to explain why Statoil chose to invest in Algeria and in the In Amenas gas field in particular.

In Chapter Four the features that have been examined in this chapter together with the theoretical foundation from Chapter Two will be used to analyze the impact terrorism has had on political-security risk in the oil and gas industry. The impact of the In Amenas attack on the oil and gas industry and the changes it may have brought about will also be examined. 


\section{Chapter Four: The Effect of Terrorism on Political-Security Risk in the Oil and Gas Industry}

\subsection{Introduction}

The oil and gas industry has always been a desired target for terrorists. During the past decade there have been numerous attacks against oil and gas facilities, primarily in the Middle East, Africa and Latin America. However, other oil and gas regions in the world have also been victims of terrorism. The political-security risk branch of political risk has recently become of interest; because of this there is a lack of literature on the subject, especially regarding its relationship to terrorism. However, by looking at the practice of the oil companies, as reported in annual reports, in articles about terrorism in the oil and gas sector, as well as in surveys and in the recent In Amenas report from Statoil, it is possible to get a picture of how terrorism has affected political-security risk in the oil and gas industry.

Up until the 9/11 terrorist attack in the US, terrorism by itself did not affect politicalsecurity risk to a significant extent. The oil and gas industry focused more on risks related to dry holes, unstable states, foreign investments, new ventures and natural hazards. Terrorist attacks did not receive much attention and very often terror incidents were labelled "industry risks" (Luft \& Korin, 2003). However, after the 9/11 attack terrorist organizations with a global reach, such as Al Qaeda, identified the world's energy system as a major vulnerability and a sure way to damage the oil-dependent economies of the Western world. The attack added a sharp new focus to the industry's approach to risk (Weinberg, Coplon \& Williams, 2008). While the EIAD database recorded 359 attacks against oil and gas facilities in 2000, the number rose to 628 in 2011 (Center for Security Studies, 2012); this led oil and gas companies to invest heavily in security measures. Large amounts of money have been spent on physical security measures around these facilities, but political-security risk management has not received the same attention. However, due to the severity of the In Amenas attack, which has been seen as a watershed moment for many companies, companies are now looking into their risk mitigation and management procedures. 
Thus far this research study has provided a comprehensive overview of theory relevant to the study, as well as an outline of the terrorist threat facing oil and gas companies in Northern Africa. This chapter is the focal point of this research study: it aims to analyze the impact terrorism has had on political-security risk management and mitigation in the oil and gas industry. In this research study, the case study is the attack on the In Amenas gas facility, run by Statoil, BP and Sonatrach The first section will focus on the security situation at the In Amenas facility before the attack, on how Statoil managed the security at the facility and on how they managed security risk at a corporate level before the attack; this is essential if one is to understand how the terrorist attack affected Statoil's political-security management strategies. In section two the main research question will be the focus of the discussion, with support from the two sub-questions. In the final section some concluding remarks will be presented.

\subsection{The Security Situation at the In Amenas Facility Before the Attack}

In the previous chapter the In Amenas attack was given a thorough review; this section will discuss the security situation at In Amenas before the attack. In order to better understand who was in charge of security risks in Statoil, a short overview of the organizational structure is in order. Figure 4.1 is used to make the organizational structure of Statoil easier to comprehend.

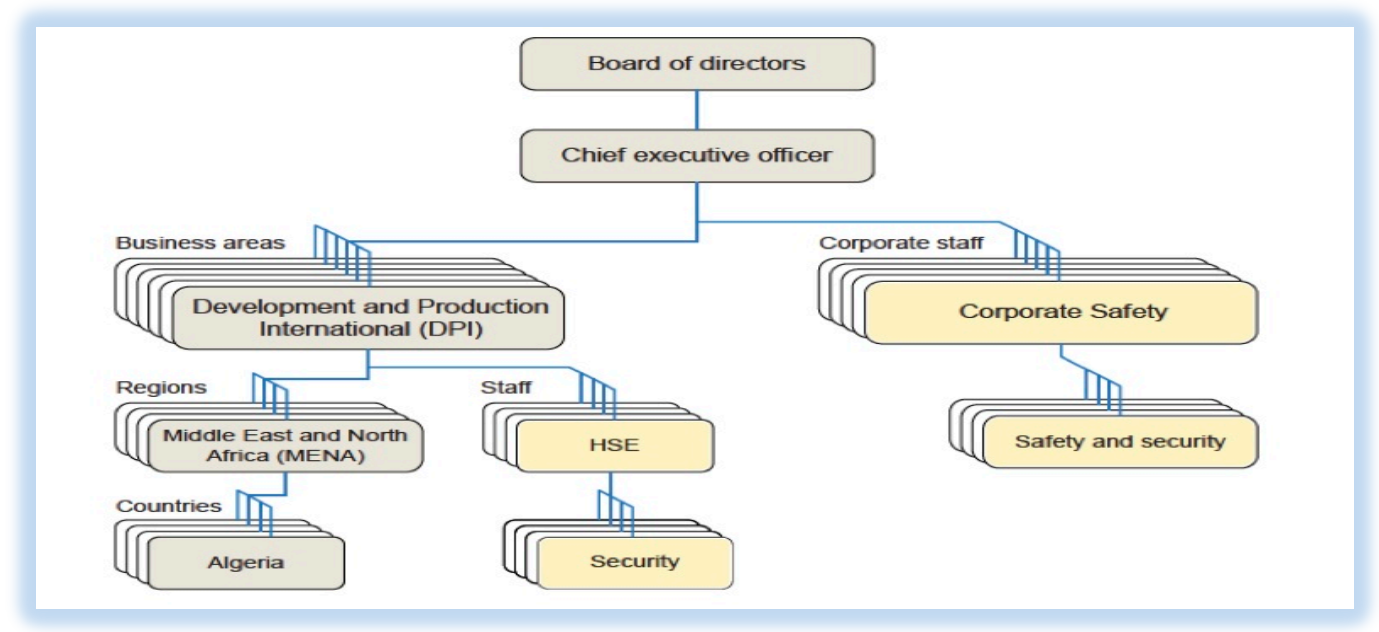

Figure 4.1: Illustrative overview of the reporting lines in Statoil (Statoil, 2013a:50).

As can be seen on the figure above, Statoil is organized into seven business areas, which are individually responsible for the security in their operations. The In Amenas project is located in the business area named "Development and Production 
International" (DPI). The leaders in each business area are members of the corporate executive committee and report to the chief executive officer (Statoil, 2014:13). Each business area is in charge of different regions. Algeria is part of the Middle East and North African region (MENA). The country office in Algiers is in charge of the In Amenas project, representing DPI (Tjelta, 2004). The corporate safety staff handled security issues, which were grouped together with the broader health, safety, and environmental matters in the company.

\subsubsection{The In Amenas Security System: Government and Corporate Responsibility.}

Prior to the attack the security at the facility was divided into four layers, which again could be divided into two groups, the outer and inner security systems. The outer system was the responsibility of the Algerian government, while the joint venture was responsible for inner security. The outer security was divided into three sections. The first was border protection, provided by the gendarme with, if needed, support from the army. The next protective layer was the military zone surrounding the facility. This zone was guarded by the Algerian army, which was based in the town of In Amenas. The communication between the army and the joint venture was maintained through meetings between the joint venture, the next-in-command of the military (located in In Amenas) and the governor of Illizi. According to the report (Statoil, 2013a), the gendarme provides protection for the site zone and is also responsible for the safe transportation of workers to and from the facility. This included the vehicle checkpoints outside the facilities.

The inner security was provided by the joint venture. This includes protective barriers, identity control when entering, training of the workers, threat assessments and civilian guards. The security measures at In Amenas were based on the security situation prevailing in 2000. In 2009 Algeria experienced an increase in bombing and violent attacks in northern Algeria. For this reason the security measures were upgraded in 2009 (Lebovich, 2011:8; Statoil, 2013a:48). The physical security measures that were put in place included double fences around the processing area and the living area, with concrete bars outside to stop incoming vehicles. At the entrance to the living and the processing area, chicanes and barriers were put up to slow down approaching vehicles (Statoil, 2013a:40). Algerian laws do not allow international oil and gas companies to 
employ armed foreign security guards; they are however allowed to use armed Algerian guards. Nevertheless, the joint venture decided to use unarmed guards and to rely instead on the gendarme and the army for armed protection (Krauss \& Kulish, 2013). The joint venture hired a liaison officer to supervise the day-to-day security, which included expatriate personnel deployed at the facility. The liaison officer was the link between the army and the joint venture and was in charge of coordinating and managing the security at the facility (Statoil, 2013a:46). The liaison officers were also responsible for providing an escort to and from the facility.

\subsubsection{The Security Risk-Management Process Before the Attack}

In addition to physical security measures at the site, a security risk management process had been put in place by the joint venture and it was the liaison officer's responsibility to administer this. The risk-managing process included a set of risk assessments, and risk management and mitigation strategies aimed at lowering the risk level to an acceptable level (Statoil, 2013a:47). The In Amenas site was seen as having strategic importance for Algeria, and because of this Statoil was required to put forward a security plan that had to be approved by the local government in Illizi. As a supplement to this a security-management plan were developed, which was supposed to be updated twice a year. A civil-crisis plan along with a risk-assessment-and-action plan was also established. The purpose of the security management plan was to review the security situation in the region and identify the most critical threats for the facility. This plan highlighted the importance of the army in the protection of the military zone, but the joint venture was not able to obtain detailed information about the army's activities and deployments. Together with local criminals and kidnapping, the threat of terrorism was always part of the security management plan. However, the generic terrorist threat was not divided into more specific categories, which would have made it easier to prepare for different scenarios (Statoil, 2013:48). The purpose of the civil-crisis plan was to prepare the joint venture for the procedures it may have to carry out in the event of a terrorist attack; it also included procedures in the event of natural disasters and civil unrest. The plan included management guidelines to ensure that risks were managed in a suitable way. 
The risk assessment and action plan was used to evaluate security risk measures before and after being implemented. On the risk assessment and action plan, terrorism was one of the sections with highest risk score (Statoil, 2013a:48). With ongoing projects Statoil's head office required a continuous risk evaluation of the security situation in the operation areas along with an analysis of appropriate security measures, but in the aftermath of the attack it have become evident that the capacity and competence required to perform such a task were limited.

Statoil has a risk management unit, with the responsibility of handling Statoil's risk management process. They have designed a standardized tool that is used at the different business levels in the company. The risk management unit is in charge of aggregating the risks from all the different business areas in the company; these then form a top-ten risk map that is presented to the board of directors and the executive committee four times a year. Very few risks are managed at the top level in Statoil (e.g. market and price risks). Security risk is among the risks handled on the business level (Statoil, 2013a:52). It is evident that Statoil has a number of risk management strategies. The next section will look at the extent to which these strategies were being used; it will also look at Statoil's risk management in practice. The section will also examine how oil and gas companies use political-security risk in their analyses before and during operations to guide their investments in volatile environments.

\subsection{The Use of Political-Security Risk in the Oil and Gas Industry}

The purpose of this research study is to find out how terrorism affects political-security risk management and mitigation in the oil and gas industry. To address this research problem, it is essential to find out to what extent international oil companies have a political-security risk strategy in place to help in their management and mitigation plans, and how much focus there is on terrorism as a security risk in the planning of new and existing operations.

\subsubsection{Economic Risk vs. Political-Security Risk}

As argued in Chapter Two, political risk has become more important in the oil and gas industry; this is because the biggest reserves are to be found in unstable regions of the world. Thus, according to KPMG Partner Mantovano, oil and gas companies have 
always been thorough when it comes to addressing risks that are function-specific, such as financial risk, exploration risk and production risk (KPMG, 2014:6). This can be seen in the annual reports of a number of the biggest oil companies in the world. In the ConocoPhillips annual report for 2013, most of the risks that are described revolve around financial risks, such as changing commodity prices, domestic and worldwide economic and political developments, together with price controls and production limitations (ConocoPhillips, 2014:27-28). The world's sixth largest oil company (Helman, 2013), Royal Dutch Shell, has much the same focus in its annual report: the emphasis is on risks associated with the global macroeconomic environment, with financial and commodity market conditions and with fluctuating prices (Royal Dutch Shell, 2014:1112). Chevron, another leading international oil company, upholds the importance of managing the risk related to the fiscal terms of contracts and changes in tax laws and regulations in their annual report. The risks connected to the company's ability to find and effectively produce oil and gas are also highlighted (Chevron, 2014:11). The same risk focus can also be seen in the annual reports for Statoil and BP prior to the In Amenas attack (Statoil, 2013c; BP, 2013). This is in line with a survey among senior executives in natural resource companies conducted by KPMG in 2014. In the KPMG survey (2014), the top risk scenarios in the industry were linked to economic risks. Sixtynine per cent of the respondents said that a global economic crisis was among the top three risks, while forty-six per cent argued that commodity price volatility was one of the top three risks.

Security risk, on the other hand, did not get as much attention in the annual reports of the same oil and gas companies. ConocoPhillips and Chevron did not mention security risks regarding terrorism in their most recent annual reports (Chevron, 2014: ConocoPhilips, 2014). The same applies to BP's annual report, published the year before the attack (BP, 2013). Of the companies mentioned above, Royal Dutch Shell has a section dedicated to security risks such as terrorism (Royal Dutch Shell, 2014:13), while Statoil in their annual report for 2012, mentions the risk of terrorism briefly in a section outlining risks regarding health, environment, safety and security (Statoil, 2013c). The absence of terrorism as a security risk in the annual reports is reflected in the KPMG survey, where only eighteen per cent of those asked rated terrorism as one of the top three risks (KPMG, 2014:6). Before the In Amenas attack security risk was not even rated among the top ten risks in Statoil's corporate risk map (Statoil, 
2013a:52). It is likely that terrorism, as a political-security risk, will be given more attention in future corporate risk maps.

This new heightened attention can already be spotted in Statoil's annual report for 2013. As mentioned in Chapter Two, terrorism does not affect businesses to the same extent as many other types of risk, but when it first occurs it is regarded extremely seriously and it becomes an eye-opener for the businesses involved. It was therefore no surprise that in the 2013 report security risk has been separated from the health, safety and environmental (HSE) agenda and is given its own section (Statoil, 2014:93). A separation like this is something that will become more common in the future, according to an Ernst \& Young report published in 2014. It has been the norm to place terrorism risk in the broader HSE risk category, but due to the fundamental difference between the traditional safety risk that has been part of the HSE category and terrorism, a different response is required from the industry. Ernst and Young (2014) continue by saying that due to the severity of the In Amenas attack, the terrorism risk has become so significant that it might become a risk category on its own in the future.

\subsubsection{Security Investments}

As stated in Chapter Two, the oil and gas industry is more likely to be affected by industry-specific risk on account of the sensitivity that surrounds a country's oil reserves (compared to many other types of industry) (Moran, 1998). This includes economical and security risk; up to the present, political-security risks have not been given the same attention as economical risks in companies' analyses. However this does not mean that they have not taken security issues, such as the threat of terrorism, seriously. Many resources have been put into what political-security risk describes as 'human security', the protection of the employees working in the oil and gas facilities around the world. Public access to oil and gas companies' security measures and expenditure is usually very limited. Total, Chevron, ENI, Statoil, BP and Royal Dutch Shell are just some of the companies that do not give out details of their security measures; this makes it difficult to know to what extent these companies are managing political-security risk (Faucon, Williams, Said \& Kent, 2013). Right after the In Amenas attack, many oil and gas companies in the region stated that they were increasing their security measures, but none of the companies was willing to say how much they had spent or to specify what kind of measures (Williams \& Amiel, 2013). However some information does get leaked 
to the public: a report from Royal Dutch Shell, published six months before the In Amenas incidence, is an example of this. The leaked report from Royal Dutch Shell gives an idea of the extensive investments oil companies make regarding human security. The document was leaked to the oil watchdog organization, Platform, in 2012 and revealed that in the period 2007-2009 Royal Dutch Shell had spent nearly \$1 billion on security measures at its facilities all over the world. Most of the spending was used for the protection of facilities and personnel in the Niger Delta in Nigeria. Over the three years, \$383 million has been used to protect Royal Dutch Shell's interests in the Niger Delta. If Royal Dutch Shell was a country, this would have put its security budget in third place in Africa (Hirsch \& Vidal, 2012). Amunwa (2012) stated that the most surprising finding in the Platform report was the ineffectiveness of the company's security spending in Nigeria, which suggests that the security situation has not improved.

\subsubsection{Regional Situational Awareness}

There is no doubt that huge amounts of money are used on security measures to protect production facilities and workers, but as stated by the Platform report, and as became evident after the In Amenas attack, oil and gas companies might benefit from expanding their view beyond the fences of the extraction area. Even though there are some companies, such as BP, that have a more complex system in place, the In Amenas attack shows how important it is that international oil and gas companies expand their situational awareness. It is of crucial importance that they broaden their risk analysis to enable them to detect and adapt to a changing transnational security environment (Thomas, 2013:4). One of the findings of the In Amenas report was that Statoil was not aware of changes in the regional security situation (Statoil, 2013a:69). Even though the In Amenas attack was an unprecedented incident, it should not be regarded as an inconceivable 'once-off'. In the investigation report Statoil argue that no company would have been able to foresee such an attack, but on several occasions in 2012 the Londonbased risk group, Exclusive Analysis, warned that oil and gas assets in southern Algeria, and foreign employees working at these facilities, could be targeted. Intelligence experts at the firm specifically mentioned the In Amenas gas facility and the risk to personnel (Jegarajah, 2013). An Exclusive Analysis report dated July 2, 2012 stated: "While the Algerian government is its primary target, the oil sector in south-west Algeria is a potential target" (Exclusive Analysis, cited in Jegarajah, 2013). Despite these clear 
warnings the joint venture did not initiate additional security measures at the facility and, as noted by Trindal (2013), the threat level system in place was also not used as a security risk management tool during 2012.

As can be seen from the numerous examples cited in the previous chapters, motivated and heavily armed terrorists have continued to show that they are capable of attacking well-guarded facilities. In the period before the In Amenas attack a number of regional events took place. One was the French intervention in Mali in support of the government's struggle against Islamic extremists, who had direct links with AQIM, MUJAO and the Masked Brigade ${ }^{7}$. Another was Belmokhtar's recent breakaway from AQIM and subsequent threats issued in December 2012. These incidents should have raised some questions about the security situation facing Western companies located in Southern Algeria (Gueye, 2014). According to Thomas (2013) international companies such as BP, which are present in a number of North African countries, place too much emphasis on the fact that they have a long-term presence and believe that this makes them less vulnerable to terrorist attacks.

In 1998 Venter wrote an article about reasoned decision-making as a management tool. His case study was the tobacco industry, but a number of his arguments can easily be applied to today's terrorist threat to the oil and gas industry. Political-security risk is difficult for the companies to control. He argues that a terrorist bombing cannot be subject to management control. Nevertheless, such incidents can and should be anticipated in the management operations of companies, and this is especially true in a large industries, such as the oil and gas industry, operating in volatile environments all over the world (Venter, 1998:6). Political-security risks are discontinuous; and can be viewed differently; they are not predictable on the basis of statistically based generalizations, for the incidents are too few and too disparate. However if the companies decide to do a fundamental descriptive analysis of the security situation regarding the transnational, national and human threats to security, this can provide the companies with early warning of impending political-security risks. As Venter says, "the issue at hand is not to be completely right, but to be more or less right" (Venter, 1998:

7 On January 11 2013, French troops intervened in Mali after a request from the government of Mali to help retake the northern parts of the country, which were controlled by several insurgent groups fighting for independence for Northern Mali (Errera, 2013). 
7). As explained in Chapter Two, risk events are often so complex and are affected by so many interrelated causes that the outcome remains uncertain, even after a detailed political-security analysis has been carried out.

Political-security risk analysis with a focus on transnational, national and human security should be used on a regular basis. The security arrangements at In Amenas was established in a period when Algeria was more politically stable. The domestic threat level was generally understood at that time, but over time the security situation became more complex and the regional threat level more uncertain (Statoil, 2013a:71). As stated in Chapter Two, there has been an ongoing problem in that oil companies fail to see risk management as a continuing process. Often the companies conduct a risk analysis when doing a new investment, but fail to use risk management as an ongoing function (Lax, 1983). The In Amenas attack clearly shows how rapidly the risk landscape can change and how the priorities of oil and gas companies should change accordingly. After the attack companies in the whole North African region were quick to look at the lessons to be learned from the incident and at the measures to be implemented to better protect the workers and facilities in the area (Ernst \& Young, 2014:10). It is a common trend among oil and gas companies to implement new security measures after an attack has hit the industry, and this was also evident after the In Amenas attack (Faucon et al., 2013; Terrapinn, 2013). Even if Statoil had done an effective politicalsecurity risk analysis before the attack it might not have prevented the attack from happening, but the attack may have been less successful.

\subsubsection{Political-Security Risk Management and the Lack of Integration.}

The joint venture was responsible for the security at In Amenas and could if necessary contact the owner companies if resources and expertise were needed. According to the findings in the investigation report this only took place to a limited extent. This might be one of the reasons why the threat level remained unchanged from February 2012 until the time of the attack. The joint venture identified a number of security issues, but it lacked the means to develop a systematic threat picture and to change their security posture (Statoil, 2013a:71). Improved communication between the joint venture and the companies involved might have improved the level of security vigilance for the In Amenas project. Combining the local insights provided by the joint venture with a more transnational perspective, provided by Statoil's corporate risk management unit, would 
have enabled a more thorough examination of the possible security risks to the In Amenas project; this would also have allowed for more options to be explored to mitigate the risk.

As Statoil has expanded its international operations, it has also expanded its ability to manage security risks. However the findings of the investigation team reveal that Statoil was not able to respond effectively to security risks in volatile areas such as Algeria. Statoil does have extensive documentation on their approach to security issues (The Statoil Book, 2013), but standard practices and methodologies were not followed consistently by the company. The process of security risk management in Statoil does, however, make an effective transformation from risk identification to action. One of the reasons for this is that security is not established as an independent function, but is a small part of the larger HSE position. This has led to a lack of full-time experts on security in Statoil. Statoil does employ security experts, but they are scattered throughout the company and are not effectively utilized. Because of this, much-needed cooperation across units and levels only happened on an irregular basis (Statoil, 2013a: 73). These findings are no surprise if one takes a look at the KPMG survey, which revealed that in forty-nine per cent of the companies those responsible for risk management did not complete a thorough risk assessment every year. Eighteen per cent of companies said that they had no system to aggregate risks and thirty-six per cent of companies stated that they used their own business units to give a risk assessment (KPMG, 2014:6). The survey also revealed that a large number of companies acknowledged the importance of risk management, but at the same time only 65 per cent of the companies participating in the survey incorporated risk management often or always in their strategic planning decisions.

The investigation, conducted after the attack, pointed out that Statoil lacked a clear holistic approach to risk management; according to a Statoil source political risk was seen as more of a PR issue. For years Statoil had employed a political risk firm in Oslo, but this firm was part of the communication department and not actively used (Bousso, 2013). It was normal procedure in Statoil to outsource political and security risk before the In Amenas attack. According to Jakobsen it is not unusual among oil and gas companies, especially the smaller ones, for the risk evaluation to be conducted on an ad hoc basis, where an external risk agency provides the analysis. He argues that this may 
lead to a lack of a more systematic strategy for risk management (Jakobsen, cited in Gitmark \& Gravklev, 2013). However, the In Amenas incident was a watershed for Statoil and the company is now setting up its own political and security risk analysis team. Based in London, the team will include former intelligence personnel and analysts, and will focus on North Africa, East Africa, China and Central Asia (Bousso, 2013). This might indicate that Statoil will place more emphasis on political-security risk in the future, but, as stated in Chapter Two, oil companies often do not succeed in managing risks until they become apparent. They often react when the incident happens, but forget to prepare for incidents that might take place in the future. Statoil's ability to manage future risks depends on its ability to make good use of the new risk unit.

A more holistic approach to securing oil and gas installations is thus needed, given the volatile areas in which oil and gas companies are investing. First, it is important that companies design strategies that fit the local context. To do this the companies must expand their capabilities with respect to political-security risk management. Better analysis of operating contexts is vital. The companies should adopt an evidence-based approach to be able to understand the power of contagion that generate clusters and to understand the motivations and attributes of brutal non-state actors. The terrorist groups operating today have a complex web of social, economic, political and ideological grievances. They also operate on a transnational level and often pursue different agendas. According to Giroux and Gilpin (2013), oil and gas companies must use multipronged strategies to find ways to isolate extremists; by using a socio-anthropological lens they would be able to gain a deeper understanding of the various groups. Enhanced cross-border collaboration that can reduce the abilities of these groups to carry out attacks is also vital. An increased focus on the three levels of political-security risk will enhance the companies' ability to manage future hazards, and reduce the terrorist risk to employees and facilities. A number of companies are bigger than Statoil and have been operating on a global scale for much longer. One of these is BP, which will be discussed in the next section.

\subsubsection{BP and the Use of Political-Security Risk}

There is a dearth of literature regarding political-security risk in the oil and gas industry. As explained in Chapter Two, this is largely because political-security risk is still a fairly new field of political risk. One has to look at alternative sources to get an idea of how the 
oil and gas companies approach political-security risk management. Even though oil and gas companies don't normally make their risk management procedures available to the public, it is still possible to gain some understanding of the different companies' risk management approaches by other means. An example is BP, which along with many other companies keeps their risk models a secret. However it is possible to gain an insight into BP's risk management approach from the perspective of its operational security; in this way one learns how BP evaluates and manages risks that they may encounter in potentially risky oil regions (Alon et al. 2006:633). Alon et al. (2006) argue that for BP, successfully managing security risk is one of the most important tasks associated with BP investments around the globe. To be able to handle the unpredictable security environment within which it operates, BP has embraced a converged risk approach to security. Instead of looking at the different risks individually, each group works closely together, harmonizing the process, and streamlining the communication and using the different groups' collective experience to identify possible overlapping risk gaps (Price WaterHouse Coopers, 2010). Investments all over the world in a number of politically unstable states have created major security concerns for oil and gas companies such as BP. However, according to Alon et al. (2006), BP has been patient in dealing with such volatile situations, and as a step towards addressing security concerns, BP's internal security system has played an important role in managing these situations.

In 1997 Knott wrote an article on BP's security strategy. Even though the article dates from 1997, it gives an indication of how BP handles security risk and it shows how BP's security policy is tailored to fit the local requirements in a specific region or situation. At the time the article was written, BP had a security organization that was headed by a number of regional security advisers, whose job was to provide security advice to BP operations in their region. Security management employs personnel with experience gained from the army, the police force and from foreign diplomatic offices. The BP security organization had a number of tasks; these included identifying threats and risks that could affect BP's facilities, prioritizing responses to security threats, and making contingency security plans, along with a number of other security tasks (Knott, 1997). BP's security plans involve close cooperation with governments in the host countries and with their armed forces. Close contact is secured through the close liaison with government agencies, including local armed forces. The main goal of the BP security 
organization was clearly stated by the then regional security adviser in the Middle East, Tony Ling: "identifying and managing risk is what we are about" (Knott, 1997). The chief principles of BP's pragmatic move towards security risk analysis include dialogue between different intelligence sources and the provision of tailored analysis, made specific to fit the different local conditions.

The next section will look at to what extent the attack on In Amenas affected the industry and examine if any major changes have happened in the way companies use politicalsecurity risk in their risk management strategies.

\subsection{Changes in the Oil and Gas Industry After the In Amenas Incident}

According to Giroux (2013) the increase in attacks against oil and gas installations requires a new discussion on the issue of security. She argues that a new security culture, new concepts, a new understanding and a more holistic approach to security risk in the oil and gas industry are needed. Effective strategies were not in place, but as a result of the In Amenas incident the industry did engage in discussion on the issue (Giroux, 2013). The unprecedented scale of the attack against In Amenas led to a boost in security spending by other companies in the area, such as Total SA and Royal Dutch Shell. The new threat represented by the attack on In Amenas caused what a senior industry executive operating in the whole North African region called a "sea change in the reality of risk" (Faucon et al. 2013). A clear illustration of the impact of the attack on the industry is that after the attack several major oil and gas companies and government officials from a number of countries met during the World Economic Forum in Davos where new security measures were discussed (Stoltenberg og Cameron sammen mot terror, 2013). The CEO of Shell, Peter Voser, stated that some initiatives were under way and that Shell was in the process of working on the mechanisms needed, but at the time of the interview this had not been completed (Faucon et al. 2013). That things were happening was also confirmed by Steven Colville (Zarroli, 2013), President of the International Association of Drilling Contractors, a forum for the oil and gas drilling industry; he stated that in his member companies there are people that constantly work on security issues, but this incident had forced them to review their security measures. 
There is a difference between the big international oil and gas companies such as BP, which have been involved in volatile regions all over the world for a long time, and the smaller companies such as Statoil, which have only recently started to invest outside Norway. Even though BP had a comprehensive internal security system in place, this was not sufficient to prevent the attack at In Amenas. The Statoil report published after the incident, together with the findings from Ernst \& Young and KPMG, illuminates some of the tendencies that were present in the way oil and gas companies dealt with politicalsecurity risk. Many have seen the In Amenas incident as a wake-up call for oil and gas companies, and there is general consent this would lead to an increase in spending on security measures (Jegarajah, 2013; Gjelten, 2013; Faucon, 2013). However, as stated by BP's director of communication, David Bickerton (cited in Golob, 2013): "What remains to be seen is if the extractives industry will re-examine its risk assessments and risk management processes in the wake of the In Amenas incident and other similar crises."

In Amenas has been an eye-opener for Statoil and other companies, not only those located in Northern Africa, but for all oil and gas companies operating in volatile environments all over the world. Due to the severity of the attack it is possible that companies will place more focus on the risk of terrorism. It is hard to say whether this will include a broader political-security risk approach or just provide another boost for measures to physically protect, but there are signs that point to an increased focus on political-security risk. At the time of writing Statoil is showing a willingness to invest more thoroughly in political-security risk through the creation of a new risk unit. Only time will tell whether this division will be actively used, or whether it will slide back into the same role as the old risk unit. However, at the moment, and with In Amenas fresh in mind, it is likely that Statoil will focus more on political-security risk than ever before.

There is however little evidence in the annual reports of the major oil companies after the attack that indicates an increased focus on security with regard to terrorism. This is not to say that here is no focus on terrorism, but it might indicate that the In Amenas attack had a short-term effect on the industry, which began to fade when the incident became more distant. As mentioned earlier, the industry was more engaged in discussions about security after the attack, but according to Giroux (2013) there have only been some minor efforts to formulate new security strategies. In her work she has 
seen few strategies that are new. There have been small changes in the way oil and gas companies operate and new ways of looking at safety and security, but there is still a long way to go. Except for the corporate changes in Statoil (with the forming of a new risk unit) and an improved focus on internal communication, there have been few major visible changes in the oil and gas industry when it comes to developing new security risk strategies. However the findings in the Ernst \& Young (2014) survey, which showed an increased focus on terrorism as a risk factor; this might indicate that changes will occur, but this is a process that will develop over a longer period than is possible to examine in this research study.

\subsection{Factors Contributing to the Attack in In Amenas and the Unsuccessful Risk Mitigation}

There are a number of factors that contributed to the attack on In Amenas. The lawless situation on Libya and Mali made it possible to Belmokhtar to easily recruit and train a well-organized terrorist group; it was also easy for the group to cross the Libyan border to carry out the attack. Belmokhtar needed to show AQIM that he was capable of executing substantial attacks; after being accused for lack of action in October 2012 (Callimachi, 2013), he needed to demonstrate that his group was an important extremist group. The In Amenas facility was a perfect target for such a statement. According to Bøås (cited in The In Amenas attack - one year after, 2014) the attack on In Amenas was an outcome of the civil war that ended in the $90 \mathrm{~s}$, when errors were committed by both the Algerian government and the international community. Belmokhtar wanted to target the Algerian state by reminding the population of the civil war. As was explained in Chapter Three, In Amenas is a gas facility of great importance for the Algeria, providing the government with important revenues. The Western companies that operated the facility were seen as collaborators with the government and there were numerous western employees working on the site. These are factors that would automatically draw international attention and an attack would be in the headlines all over the Western world. A number of elements help to explain why attempts at risk mitigation before the In Amenas attack were not successful. For the purpose of this study seven main findings has been extracted from the report and compiled. 
Table 4.1: Main finding in the In Amenas report.

\begin{tabular}{|l|l|}
\hline 1 & $\begin{array}{l}\text { No early warning information was available on the likelihood of an } \\
\text { attack. }\end{array}$ \\
\hline 2 & $\begin{array}{l}\text { The joint venture relied too much on the government security forces for } \\
\text { control over security issues outside the facility. }\end{array}$ \\
\hline 3 & $\begin{array}{l}\text { The physical security measures at the facility were not sufficient to stop } \\
\text { the attack. }\end{array}$ \\
\hline 4 & Poor communication with the local community. \\
\hline 5 & Security at corporate level was part of the health and safety unit. \\
\hline 6 & $\begin{array}{l}\text { Joint venture projects can experience problems when it comes to } \\
\text { cooperation and coordinating security measures. }\end{array}$ \\
\hline 7 & $\begin{array}{l}\text { Poor situational awareness regarding changes in national and regional } \\
\text { security situations. }\end{array}$ \\
\hline
\end{tabular}

(Source: Adapted from, Statoil, 2013a).

The table clearly shows that Statoil lacked focus on all the three levels of politicalsecurity risk. On the human security level, the report revealed that the physical security measures in place were not sufficient to prevent the attack. The insufficient communication with the local community, as well as the poor recognition of the changing security situation on a regional and national level, also shows serious limitations on the national and transnational level of political-security risk management. The security system that was in place at In Amenas was established in a period of regional stability in the context of a well-understood domestic threat environment, but during 2011 and 2012 the security situation in the region changed dramatically for the worse. The civil war in Libya turned a former relatively stable neighbour into a chaotic country where terrorists could easily move around (Goldstone, 2011:459). At the same time Mali was becoming a safe-haven for terrorist and extremist groups (Cafiero, 2014). Changes like these require a systematic political-security risk management process to bring the company up to date with possible security risks. As stated in Chapter Two, political-security risk need to be constantly observed, if not the company will end up with outdated information, making it difficult to manage possible risks. In the case of In Amenas this did not happen. Even though the transnational security environment had changed dramatically, the In Amenas joint venture did not change its threat level: this remained unchanged from February 2012 until the attack, almost a year later (Statoil, 2013a:71). Discussions on security issues at the facility were hampered by a lack of communication internally in the joint venture regarding the security risks. According to the Statoil report there were 
numerous examples of significant joint-venture security and crisis response plans that were not shared with key personnel at the facility. Even personnel responsible for the implementation of such measures were not included in these discussions (Statoil, 2013a:72). The managers at the facility had limited information, which made it more difficult to decide on implementing new strategies. Closer cooperation between the joint venture and the owner companies on issues regarding security would have made it easier for the leaders at In Amenas to apply measures to deal with the new security environment.

As explained in Chapter Two, by combining a transnational perspective with a better understanding of the national conditions, it is possible to broaden the discussion on security issues and at the same time increase situational awareness. In the case of In Amenas this would have made it possible to more rigorously consider a wider range of choices to mitigate the security risk.

Statoil's lack of effective political-security risk management is something that is evident throughout the company. Since Statoil's first entry into Algeria in 2003, the company has expanded its international investments sevenfold (Jukov, 2012). Since then the company have increased its capacity to manage security risks, but the company's overall capability and culture have to be improved in order to respond to the security risks that are related to operations in unpredictable and complex environments. In the In Amenas report it was pointed out that Statoil lacked a culture which recognized that security was everyone's responsibility (Statoil, 2013a:73). Extensive governing documentation on how to handle security risk is of little use if it is not followed up by the company.

Now, one-and-a-half years after the attack, foreign workers are starting to return to In Amenas (Langved, 2014). New security measures have been implemented and it has been decided that the these security measures are sufficient. Below is a table of some of these new measures. This list has been compiled for the purposes of this research study in order to illustrate what political-security risk changes Statoil did after the attack. The list consist of the seven most important new security measures at the site and at corporate level. 
Table 4.2: New security measures

\begin{tabular}{|l|l|}
\hline 1 & Improved control of people entering the facility. \\
\hline 2 & Better control of people coming near the plant. \\
\hline 3 & Upgraded barriers around the site. \\
\hline 4 & An airport has been built inside the site. \\
\hline 5 & Permanent military personnel on the site. \\
\hline 6 & Helicopters scanning the area. \\
\hline 7 & New improved risk unit located in London. \\
\hline
\end{tabular}

(Source: Adapted from, Dagenborg \& Chikhi, 2014; Bousso, 2013).

As is evident from the table, Statoil have made a number of changes both at the In Amenas gas site as well as at a corporate level to improve the security situation. While the physical measures are limited to In Amenas, the introduction of a risk unit is a measure that will be helpful for Statoil's other ongoing operations as well as for future investments in other unpredictable regions in the world. As seen in table 4.4, the new measures cover all three levels of political-security risk. The security measures on the human security level have been substantially upgraded as is apparent in points one through six, while national and transnational security is incorporated in point seven. The new and improved risk unit is one of the most important new measures since risk need continuous monitoring, an important factor Statoil often neglected in the past.

\subsection{The Management of Terrorism and Complications with Mitigation.}

Because of the importance of oil and gas in today's world economy, it is difficult to completely mitigate the risk of terrorism in the oil and gas industry. This, combined with the sensitivity surrounding petroleum operations, caused by the view that the oil and gas resources are a country's "national patrimony" (Alon et.al., 2006:631), presents a challenge to oil and gas companies all over the world. As revealed by the EIAD database, the number of attacks on energy infrastructure has been increasing since the early 1990s (Giroux \& Gilpin, 2013). This includes attacks against onshore oil and gas installations, as well as against offshore targets such as tankers and oil platforms in key transit corridors like the Indian Ocean and the Gulf of Guinea (Giroux \& Burgherr, 2012), Data from EIAD also indicates that terrorist attacks have a tendency to cluster in certain 
regions and over time these form a wake-like pattern. According to Giroux and Gilpin: "the crests of these waves tend to correspond with flashpoints of instability characterized by localized "bursts" of violence aimed at energy infrastructure" (Giroux \& Gilpin, 2013). Such clusters have occurred in the Middle East, South America, South Asia and Northern Africa (Giroux \& Gilpin, 2013). Given this information, it is evident that political instability in the country of production and in the surrounding region causes an increase in attacks, and these can develop into clusters. The unstable situation in Algeria and the neighbouring countries, combined with the In Amenas attack, as well as smaller attacks against pipelines and personnel in Algeria, can indicate the possibility of a new cluster of attacks against the oil and gas industry in Northern Africa.

Another factor making it difficult to mitigate terrorism is the world's dependence on oil and gas. All over the globe income from oil and gas exports is an important revenue source for regime budgets. In Algeria oil and gas exports alone account for more than 95 per cent of foreign currency earnings (Belalloufi, 2013). As stated in Chapter Three, by attacking vital oil and gas infrastructure terrorist groups are able to strike a direct blow against the regime and its international partners. With the world's rising demand for oil and gas it is likely that the number of terrorist attacks will increase in the future. A $\$ 10$ increase in real oil prices is associated with a decrease in the world economic growth rate of between 0,4 and 1 per cent (Mingqi, 2012) As stated by Johnston (2008), this gives terrorist groups an incentive to attack oil and gas installations as a way of damaging the economy of the Western powers, which has been one of the goals of $\mathrm{Al}$ Qaeda since the 1990s.

At the time of writing, the US's oil imports are declining, but this does not mean that the US will become less affected by terrorist attacks against oil and gas facilities. The US economy is closely linked to oil and is still to a large degree affected by what happens on the international market. Disruptions to supply from important Middle Eastern countries such as Saudi Arabia and Iran still have a big impact on the American economy (Plumer, 2014). Europe's oil dependence is also expected to grow and it is estimated that oil imports will rise by 78 per cent by 2035 and gas imports by 64 per cent (Klare, 2014). The world's total demand for oil will, according to Organization of the Petroleum Exporting Countries (OPEC), continue to increase in the coming years (Zhdannikov \& Johnson, 2014). These factors make the oil and gas industry a lucrative 
target. At the same time there is growing investment in the oil and gas industry and in the future there will be more oil and gas installations, more pipelines and more entry points, making it easier for extremist groups to find accessible targets. According to Giroux (2013) and numbers from the EIAD database (Centre for Security Studies, 2012), it is likely that we will see more attacks in the future, not fewer attacks. The next section of this chapter will provide the oil and gas industry with some risk management recommendations regarding investment in volatile regions.

\subsection{Risk Management Recommendations for the Oil and Gas Industry.}

It has been pointed out that after the In Amenas attack Statoil lacked an overview of what was happening both at a national level and at a trans-national level. Based on the numbers that came up in the KPMG (2014) survey it is reasonable to believe that there also are other companies that have an inadequate overview of the situation in areas they operate in. For this reason this study will here briefly present some recommendations that will improve the ability of oil and gas companies to identify and manage future security threats. The first recommendation is to make use of a designated risk unit. This unit does not necessarily have to be a part of the company, but as stated previiously, this is preferable since it is not certain that external analysts will be able maintain a systematic strategy regarding risk management (Gitmark \& Gravklev, 2013). It is important that companies develop their capacity to manage security risks, especially in an industry such as the oil and gas industry, which operates in complex and volatile regions. Understanding security risk is an important foundation for effective political-security risk management.

A second recommendation is to make use of political-security risk analysis. By analyzing the three levels of security (transnational, national and human security) a company will be better equipped to handle future security issues. Attending to these three levels of security will provide a well-rounded and comprehensive analysis. In today's globalized world it is no longer enough to have an idea of what is happening in the region close to the production site. Regional events have to be seen in relation to what is happening on a national and transnational level. The In Amenas terrorist attack is a perfect example of this. Nowadays the world is changing at an increasing rate, and this demands more of companies. 
A third recommendation is that it is crucially important that information obtained by the risk unit is communicated throughout the whole corporate structure. It is vital that the company has a holistic approach to addressing security risks. Having good communication lines will make it easier for the company to be better informed on security issues; at the same time this will improve the situational awareness. This will allow for a more rigorous examination of a broader range of options to mitigate possible security risks.

A final recommendation is that there must be a continuous focus on risk at all times. In most cases it will not be possible a company to eliminate the security risk. It is therefore important that companies have a clear understanding of the remaining risks and of whether these are acceptable. Risk analysis is not something that should only be performed before deciding about a new investment. For effective risk management, continuous evaluation must be conducted before and during international operations, in order to be prepared should conditions change. This is especially important since oil and gas companies are now being forced to invest in increasingly volatile and uncertain regions where there are still available oil and gas reserves. Reports on risk levels have to be continuously reviewed, monitored and updated.

\subsection{Conclusion.}

The effect of terrorism on political-security risk can be questioned. As has been recognized in this chapter, the oil and gas industry has been affected by terrorism for many years without there being a substantial focus on a more holistic approach to the risk of terrorism. As for Statoil, political-security risk management has not been given as much attention as other risks, such as economic and production risks. The In Amenas attack however, might act as a wakeup call for oil and gas companies, especially those that have production facilities in Northern Africa and the Middle East. Changes are now underway and Statoil is creating a new political risk unit that will have a more central role in the company's international operations than was the case before. As mentioned, there are signs in the industry that the companies are more eager to enter into discussion on political-security risk and its importance following the In Amenas attack. Because of the importance of oil and gas for the economies of the producing countries, as well as for the world economy it is not possible to totally mitigate the risk of terrorism. 
However a comprehensive political-security risk analysis before and during production will increase the oil and gas companies' ability to be aware of and prepare for incidents that may affect their personnel or facilities. 


\section{Chapter Five: Conclusion and Evaluation of the Research Study}

\subsection{Introduction}

International oil and gas companies consistently put themselves at risk when investing in unstable areas. A continuous assessment of political-security risk in these countries is essential in facilitating successful investments and is of great importance for the safety of the employees of the companies. The very nature of their business is forcing the oil and gas companies to invest in regions which are high-risk environments. The ability of the companies to easily identify and analyze political-security risks in the countries they are operating in or considering investing in is thus crucial. In chapter one, the main research question was stated as: "What is the impact of terrorism on political-security risk management and mitigation in the oil and gas industry?" This question can now be answered accordingly.

In the 1980s, Staphenhurst noticed a decline in the use of political risk assessment by companies (Staphenhurst, cited in Howell \& Chaddick, 1994). Even though international companies today are more aware of political risk and use political risk assessments more effectively, some of the factors Staphenhurst cited are still present in the oil and gas industry. He argues that many companies failed to include the findings from political risk analysis in their corporate decision-making - because many executives viewed this as unnecessary. This can be seen in Statoil's corporate attitude towards security risk management prior to the In Amenas incident. After one of the most severe attacks against the oil and gas industry there are now noticeable changes at Statoil, particularly with the creation of a new risk unit. The industry in general is re-evaluating its risk management strategies, and in particular the security risk situations in northern Africa and the Middle East are being examined. The oil and gas industry has always had a strong focus on security, but in an industry worth billions the companies are willing to accept high risk in return for high reward. It is thus crucial that there is effective politicalsecurity risk management.

This chapter concludes this research study with an overview of progress in relation to the research question as well as in relation to the aims and objectives of the study. The chapter also provides an evaluation of the research study and ends with a number of 
recommendations for further studies in the field of political-security risk and its relationship with the oil and gas industry.

\subsection{Progress of the Research Study}

Chapter One introduced the research study. This was followed by a brief literature review, focussing on the areas relevant to this research. This included influential texts on the topics of political- and political-security risk and industry-specific risk in the oil and gas industry. Literature on terrorism in the oil and gas industry, as well as in Algeria, was examined. The review concluded by presenting texts that examined Statoil's involvement in Algeria and that dealt with the In Amenas terrorist attack. The research question was presented along with two sub-questions, developed to support the main research question. The objectives and relevance of the study were discussed and the research design and methodology were outlined. This was followed by a section which delineated the research study. The first chapter ended with an outline of the research study.

The purpose of Chapter Two was to present the theoretical grounding for this study as well as to contextualize the central concepts of the study. The theoretical grounding is based on rational-choice theory, as well as problem-solving and decision-making theory, giving the research a firm framework. A number of central concepts were clarified, including risk, political risk, political-security risk, macro- and micro-risk, industry- and firm-specific risk, risk management and mitigation as well as terrorism. By examining these concepts, this chapter was able to establish a solid foundation, on which this research study could build in Chapters Three and Four.

Chapter three contextualized the impact of terrorism on the global oil and gas industry. The period from 1996, when Al Qaeda declared war on the Western world, until present was the focal point. To be able to understand the conditions in which oil and gas companies are operating and what they have to deal with in their risk management processes, the evolution of terrorism in Northern Africa was outlined, with a particular focus on terrorism in Algeria and on the most influential terrorist groups. This followed the time period from the old GIA to today's AQIM and the Masked Brigade. The aim of this chapter was to discuss the terrorist threat that international oil and gas companies face, with a focus on Northern Africa and Algeria in particular. Statoil's international 
operations and more importantly its presence in Algeria, was also scrutinized, and this provided valuable information for the forthcoming analysis.

In Chapter Four the theory presented in Chapter Two was used to analyze the impact terrorism has had on political-security risk management in the oil and gas industry. The two sub-questions were used to supplement the research question and to enhance the quality of the analysis. In this chapter the case study was also scrutinized to obtain a better understanding of how an oil company manages political-security risk before and after an attack.

\subsection{Main Findings of the Research}

The objective of this research study was to find out how or to what extent the risk management and mitigation strategies in the oil and gas industry are being affected by terrorism. If oil and gas companies do not conduct a thorough risk analysis when investing in new oil fields in volatile regions, they may place their facilities and personnel in unnecessary danger. The purpose of this study was not to conduct a risk analysis, but to increase knowledge about the use of political-security risk in the oil and gas industry, as well as examine to what extent terrorism has affected how oil and gas companies use political-security risk analysis as a management and mitigation tool before and during operations. The main research question in this study is: "What is the impact of terrorism on political-security risk management and mitigation in the oil and gas industry?" To be able to answer that question, the theory presented in Chapter Two has been used to examine the sources presented in Chapter Four. The case study of the In Amenas terrorist attack has complemented the research question by providing a deeper understanding of how an oil and gas company utilizes political-security risk management.

The findings in this research study revealed that the impact of terrorism on politicalsecurity risk management in the oil and gas industry has been limited. There has been an increased focus on the human security level, but the same attention has not been given to the national and transnational level. However after the In Amenas incidence minor changes have been observed in the oil and gas industry. A more detailed explanation will here follow. 
A company's strategic planning is important for the profitability of the company and political risk management is an essential resource in this strategic planning process. Already in the 1980s it was normal for many international companies to see political risk assessment as less than essential when conducting business in foreign countries (Howell \& Chaddick, 1994). The same tendencies can be seen today regarding security risk, as is evident in the KPMG (2014) survey. Even though there has been an obvious increase in terrorist attacks since 2000, the focus on a holistic political-security risk approach has not kept up with the threat to the industry. Terrorism has often been labelled as an industry risk, and as something one just has to accept in this type of industry (Luft \& Korin, 2003). The increased focus on the oil and gas industry as a legitimate terrorist target started in the 1990s, and led to an increased emphasis on the human security aspect of political-security risk. The industry invested millions of dollars on physical security around their facilities. Fences, concrete barriers, video surveillance and guards were just some of the measures used to manage the terrorist threat. However, a more comprehensive focus on the national and transnational kinds of political-security risk seems to have been given less attention. The case study provides a good example of how these two elements were often downgraded. Up until the In Amenas attack terrorism had little effect on political-security risk management and mitigation in the industry, except on the human security level. However, because of the severity of the In Amenas assault there were some noticeable changes in the industry (Faucon et al. 2013; Stoltenberg og Cameron sammen mot terror, 2013). A terrorist attack of the kind seen at In Amenas might be what was needed for the industry to focus on a more holistic political-security risk approach to terrorism. As stated by Giroux (2013) little has happened in the industry so far, but there are some signs that changes are taking place. The oil and gas meeting during the World Economic Forum in Davos is an example of the industry trying to find ways to deal with the growing risk of terrorism (Stoltenberg og Cameron sammen mot terror, 2013). In an industry as big as the oil and gas industry, it takes time to change deeply rooted views and ideas, but an extreme accident such as the In Amenas attack might be just what is needed to make the industry see the value of a heightened focus on political-security risk.

The first sub-question asked, "What factors contributed to the attack on In Amenas and why was risk mitigation not successful?". A number of regional factors contributed to the 
attack on In Amenas. The disruptive situation in the neighboring countries made it ideal to recruit and train for Belmokhtar and his terrorist group. The location of In Amenas, close to the Libyan boards also made it an ideal target. One of the reasons for the lack of success with mitigation was that it became evident after the attack that Statoil did not have a thorough political-security risk management strategy. The In Amenas report revealed a number of factors that played a role in this failure of risk mitigation, including poor situational awareness and the fact that security was not independent; it was part of the health and security unit. Possible security risks were also poorly communicated throughout the company. It was also stated that the physical security measures at the site where not sufficient, a possible consequence of the inadequate situational awareness. A serious incident had to take place before Statoil decided that risk management had to be reviewed.

The second sub-questions was, "Is it possible for international oil and gas companies to mitigate the risk of terrorism, or can the risk only be managed?" The findings revealed that it is almost impossible to mitigate the risk of terrorism completely. In a world where the economy is to a great extent oil-driven, the companies producing this commodity will continue to be prime targets for terrorists. With fewer and fewer new discoveries being made, companies are being forced to invest in the more insecure regions of the world. Many of the countries that produce oil and gas are highly dependent on revenues from the oil industry. This helps to explain why the oil and gas industry is a preferred target for terrorists who want to harm their governments. It becomes increasingly important that companies that decide to invest in volatile areas have a comprehensive politicalsecurity risk management strategy in place. Again, the In Amenas attack can be used as an example. The In Amenas report clearly stated that Statoil had a poor situational awareness on a national and transnational level. There was also a lack of focus on security risk in the corporate structure. A clearer focus on continuous risk analysis could have improved Statoil's regional understanding and would have meant they were better prepared for potential attacks. While it is not possible to completely mitigate the risk of terrorism, the companies accept the consequences and increase their atempts to manage the risk through the use of proper means. 


\subsection{Evaluation of the Research Study}

The oil and gas industry is forced to invest where the oil and gas fields are located. In many cases they are forced to invest in regions that might be regarded as high-risk. When such investment decisions are made, political-security risk can merge with the companies' interests and play an important role. Political-security risk analysis enables companies to be better able to predict issues that are associated with the investment; this is vital for the success of the investment. The purpose of this research study was to examine the effect of terrorism on political-security risk in the oil and gas industry. To supplement the research question, the terrorist attack against the In Amenas gas facility in Algeria, which was operated in a joint venture between Statoil, BP and Sonatrach, was chosen as a case study. In Amenas was chosen because this was one of the most serious attacks the oil and gas industry had ever experienced. The attack also happened relatively recently, which made the study more relevant: it illustrated how an oil company at the present time was handling political-security risk. The In Amenas incident proved to be well suited as a case study because of the amount of available information with regard to the incident, and because of Statoil's security risk management at the site and the company's security risk management at the corporate level.

The field of political risk is complex and wide-ranging, with numerous different sub-fields and definitions. The choice of a definition was resolved after a thorough examination of a number of political risk definitions; the result was an informed conceptualization of the term. The political-risk sub-field of political-security risk was chosen due to the very nature of terrorism, which has to be examined both at the national and transnational levels. A clear definition was arrived at, and together with the political risk definition, this provided a strong foundation for the rest of the research.

One of the biggest challenges for this research was to gain access to primary data. International oil and gas companies do not give out detailed information about their risk management strategies because of security concerns. Access to models used by the political risk industry has also been limited due to the intellectual property rights of the risk companies. What is available are models that have been remodelled by researchers who have studied the behaviour of companies that use political risk models; their aim is 
to gain a deeper understanding of the elements that these models consist of. Scrutinizing other available source such as companies' webpages, scientific articles, newspaper articles, as well as surveys done among oil and gas companies has provided the primary data needed for this research study.

\subsection{Recommendations for Further Research}

Political risk is inter-disciplinary, and draws on fields such as economics, security studies, international relations, political science and development studies. These fields are constantly evolving and this affects the theory and methods of the study of political risk and its sub-branches, such as political-security risk. As a relatively new branch, the field of political-security risk is under-researched (in comparison with political risk) and the connection between political risk theory and security studies needs to be expanded on by further research.

Another recommendation has to do with how research is being conducted on politicalsecurity risk management in the oil and gas industry with regard to terrorism. To be able to identify how oil and gas companies are managing political-security risk, primary research is needed. Conducting field analysis to obtain better data on the strengths and limitations of the oil and gas companies' political-security risk analysis would help our understanding of how these companies handle the risk of terrorism. Interviews with personnel in charge of risk units in oil and gas companies would be invaluable in providing deeper insights. Primary research on terrorist groups would provide a greater understanding of their motivations and methods and would also inform the field of political-security risk management for international oil and gas companies operating in volatile environments. A more extensive use of primary data would assist in providing deeper knowledge, thereby enabling a better understanding of the use of politicalsecurity risk by oil and gas companies operating in countries vulnrable to terrorism.

The In Amenas incident was one of the most severe attacks against a gas facility in the history of the industry, and a number of oil and gas companies started to search for new answers to the security risks they were facing. It has only been one-and-a-half years since the terror attack and international gas companies are still adapting to the new 
security challenges, but small changes can be seen. One example is Statoil's new risk unit. Further research could incorporate a longitudinal study, analyzing if the changes that are now happening in the industry are just temporary or if this is evidence of a more permanent change in the way oil and gas companies make use of political-security risk in their operations.

\subsection{Conclusion}

Political-security risk is increasingly important for the oil and gas industry. International oil and gas companies consistently put themselves at risk when investing in unstable areas. A continuous assessment of political-security risks in these countries is necessary to ensure that investments are successful. This is very important for the safety of the employees of these companies. The demand for oil and gas continues to increase; at the same time fewer new discoveries are being made in what can be seen as safe regions. This means that oil and gas companies are forced to enter new highrisk areas. This has led to an increase in the number of terrorist attacks against oil and gas personnel and facilities. In an increasingly volatile world it is crucial that oil and gas companies undertake rigorous political-security risk analysis before as well as during operations. Failing to do so can lead, in a worst-case scenario, to a new tragedy such as that at In Amenas. This research study has contributed to the wider debate regarding the oil and gas industry and its relation to the field of political-security risk; it has demonstrated the importance of a well-defined political-security risk strategy. The industry has so far failed to focus on a holistic approach to political-security risk, but the severity of the In Amenas attack has led the industry to look for new answers to security risks. Looking into the future, political-security risk are likely to become more, not less, relevant to the oil and gas industry. There is as yet no "end of history" in sight. The oil and gas industry will continue to be a target for terrorists, but by applying an effective political-security risk analysis strategy, the threat of terrorism can be better understood, explained and ultimately better managed. This would make it more possible for oil and gas companies to continue to invest and operate in high-risk areas. 


\section{Bibliography}

About the In Salah gas joint venture. 2010. In Salah Gas. [Online]. Available: http://www.insalahco2.com/index.php/en/low-co2-gas-production/jointventure.html [2014, June 23].

Abullahi, A.M. 2007. The Ogaden National Liberation Front (ONLF): The Dilemma of Its Struggle in Ethiopia. African Political Economy. 34(113): 556-562.

Abuza, Z. 2003. Militant Islam in Southeast Asia. Crucible of Terror. Colorado: Lynne Rienner Publishers, Inc.

Ahmed, A. 2013. At least 37 hostages killed in Algeria gas plant standoff, prime minister says. $\quad$ [Online]. 23 January. Available: http://edition.cnn.com/2013/01/21/world/africa/algeria-hostage-crisis/ [2014, June 1].

Alexander, Y. 2014. Terrorism in North Africa and the Sahel in 2013. Fifth Annual Report. United Sates of America: International Center for Terrorism Studies.

Alkhereiji, M. 2005. Bin Laden moves toward economic terror. The Daily Star. [Online]. 24 January. Available: http://www.dailystar.com.lb/Opinion/Commentary/2005/Jan-24/96171-bin-ladenmoves-toward-economic-terror.ashx\#axzz34E8wQ9kk [2014, June 10].

Alon, I., Gurumoorthy, R., Mitchell, M.C. \& Steen, T. 2006. Managing Micropolitical Risk: A Cross-Sector Examination. Thunderbird International Business Review, 48(5), p. 623-642.

Alon I. \& Martin, M.A. 1998. A Normative Model of Macro Political Risk Assessment. Multinational Business Review. 6(2): 10-19. 
Alon, I., \& Herbert, T.T. 2009. A stranger in a strange land: Micro political risk and multinational firm. Business Horizons. 52(2): 127-137.

Amunwa, B. 2012 Dirty Work. Shell's Security Spending in Nigeria and Beyond. London: Platform. [Online]. Available: http://platformlondon.org/wpcontent/uploads/2012/08/Dirty-work-Shell's-security-spending-in-Nigeria-andbeyond-Platform-August-2012.pdf [2014, June 27].

Andreassen, T.A. 2013. Han er Algeries nye helt etter angrepet i In Amenas. Aftenposten. 27 January. [Online]. Available: http://www.aftenposten.no/nyheter/uriks/Han-er-Algeries-nye-helt-etter-angrepet-iIn-Amenas-7103971.htm|\#.U6FbAV7VtyQ [2014, June 1].

Aronosn. S.L. 2014. AQIM's Threat to Western Interests in the Sahel. CTC Sentinel. 7(4): 6-10.

Badey, T.J. 1998. Defining international terrorism: A pragmatic approach. Terrorism and Political Violence. 10(1): 90-107.

Bala-Gbogbo, E. 2014. Nigeria's MEND Rebels Threaten Future Attack on Oil Industry. Bloomberg. [Online]. 27 January. Available: http://www.bloomberg.com/news/2014-01-27/nigeria-s-mend-rebels-threatenfuture-attack-on-oil-industry.html [2014, May 26].

BBC, 2004. Gunmen killed 22 in Saudi city. BBC News. [Online]. 30 May. Available: http://news.bbc.co.uk/2/hi/middle_east/3762423.stm [2014, April 25].

BBC, 2006. Algeria bomb targets oil workers. BBC News. [Online]. 10 December. Available: http://news.bbc.co.uk/2/hi/africa/6167475.stm [2014, June 4]. 
Belalloufi, A. 2013. Algeria looks at 'reindustrialisation' to reduce dependence on oil and gas. Business Day. [Online]. 14 October. Available: http://www.bdlive.co.za/africa/africannews/2013/10/14/algeria-looks-atreindustrialisation-to-reduce-dependence-on-oil-and-gas [2014 August 13].

Berlin, A., Berlin, A.I. \& Vrooman LLP. 2003. Managing Political Risk in the Oil and Gas industries. Oil, Gas \& Energy Law Intelligence, [e-journal] 1(2). Available:<http://d.yimg.com/kq/groups/3862917/1676412124/name/Managing\%20 Political\%20Risk\%20in\%20the\%200il\%20and\%20Gas\%20Industries.pdf> [2014, April 2].

Bhatt, A. 2007. Global Terrorism. New Delhi: Lotus Press.

Black, A. 2009. Mokhtar Belmokhtar: The Algerian Jihad's Southern Amir. Terrorism Monitor. 7(12): 8-11.

Botha, A. 2008. Terrorism in the Maghreb. The Transnationalisation of Domestic Terrorism. Pretoria: Institute for Security Studies.

Bousso, R. 2013. After Algeria attack, Statoil sets up risk unit. Reuters. [Online]. 13 September. Available: http://www.reuters.com/article/2013/09/13/statoil-riskidUSL5NOH91SH20130913 [2014, March 20].

BP, 2013. Annual Report, 2012. London: British Petroleum.

BP, 2013. BP Statistical Review of World Energy June 2013. [Online]. Available: http://www.bp.com/content/dam/bp/pdf/statisticalreview/statistical_review_of_world_energy_2013.pdf [2014, May 16].

Bray, J. 2003. Attracting Reputable Companies to Risky Environments: Petroleum and Mining Companies, in Bannon, I. \& Collier, P (eds.). Natural Resources and Violent Conflict: Options and Actions. Washington DC: World Bank. 287-352. 
Bremmer, I. \& Keat, P. 2009. The Fat Tail, The Power of Political Knowledge For Strategic Investing. New York: Oxford University Press.

Brewer, T.L. 1981. Political Risk Assessment for Foreign Direct Investment Decisions: Better Methods for Better Results. Columbia Journal of World Business, 16(1): 512.

Brink, C.H. 2004. Measuring Political Risk. Aldershot: Ashgate Publishing Limited

Burnham, P., Lutz K.G., Grant, W. \& Layton-Henry, Z. 2008. Research Methods in Politics. New York: Palgrave Macmillan.

Butler, K.C. \& Joaquin, D.C. 1998. Political Risk and the Return on Foreign Direct Investment. Journal of International Business Studies. 29(3): 599-607.

Cafiero, G. 2014. Algeria's northern Mali headache: North Africa-issue in focus. Africa Conflict Monthly Monitor, 25-29.

Callimachi, R. 2013. Rise of al-Qaeda Sahara terrorist. The Associated Press. [Online]. 25 May. Available: http://www.ap.org/Content/AP-In-The-News/2013/APExclusive-Rise-of-al-Qaida-Sahara-terrorist [2014, June 5].

Center for Security Studies. 2012. Energy Infrastructure Attack Database. Zurich. [Online]. Available: http://www.css.ethz.ch/research/research_projects/index/EIAD [2014, June 10].

Chevron, 2014. 2013 Annual report. San Ramon: Chevron. 
Chiodo, A. \& Owyang, M.T. 2002. A case study of a currency crisis: The Russian default of 1998. Federal Reserve Bank of St. Louis Review, 84 (November/December): 7-18.

Chrisafis, A., Borger, J., McCurry, J. \& Macalister, T. 2013. Timeline of the In Amenas siege. The Guardian. [Online]. 25 January. Available: http://www.theguardian.com/world/2013/jan/25/in-amenas-timeline-siege-algeria [2014, March 14].

Cilliers, J. 2003. Terrorism and Africa. African Security Review. 12(4): 91-103.

Connors, W. 2008. New Attacks on Pipelines in Delta of Nigeria. The New York Times. [Online]. $\quad 17 \quad$ September. $\quad$ Available: http://www.nytimes.com/2008/09/18/world/africa/18nigeria.html?_r=0 [2014, April 1].

ConocoPhillips. 2014. 2013 Annual Report. Houston: ConocoPhillips.

Crenshaw, M. 2011. Explaining Terrorism. London: Routledge.

CSIS (Center for Strategic \& International Studies), 2010. Conference report. The Dynamics of North African Terrorism. Washington DC: Center for Strategic \& International Studies.

Dagenborg, J. \& Chikhi, L. 2014. Algeria's In Amenas gas plant returning to normal after attack. Reuters. [Online]. 1 September. Available: http://uk.finance.yahoo.com/news/normal-operations-amenas-gas-plant064705443.html [2014, September 2].

Disraeli, B. 1900. Endymion. London: Longmans, Green

Dupasquier, C. \& Osakwe, P.N. 2006. Foreign direct investment in Africa: Performance, challenges, and responsibilities. Journal of Asian Economics. 17(2): 241-260. 
Erlanger, S. \& Nossiter, A. 2013. Jihad 'Prince', a Kidnapper, Is Tied to Raid. The New York Times. [Online]. 17 January. Available: http://www.nytimes.com/2013/01/18/world/africa/mokhtar-belmokhtar-thought-tobe-kidnappings-mastermind.html?pagewanted=1\&_r=1\& [2014, June 5].

Ernst \& Young, 2012. Natural gas in Africa. The frontiers of the Golden Age. [Online]. Available: http://www.ey.com/Publication/vwLUAssets/Natural_gas_in_Africa__The_frontiers_of the_Golden_Age/\$FILE/Natural\%20Gas\%20in\%20Africa_28S ep2012LR.pdf [2013, June 23].

Ernst \& Young. 2014. Business Pulse. Exploring dual perspectives on the top risks and opportunities in 2013 and beyond. Oil and gas report. [Online]. Available: http://www.ey.com/Publication/vwLUAssets/Business_pulse_oil_and_gas/\$FILE/E230-

1212_Risk_and_Opps_\%20Business\%20pulse_Oil_and_Gas_Final.pdf [2014, June 20].

Errera, G. 2013. France had to intervene in Mali. Financial Times. [Online]. 16 January. Available: $\quad$ http://www.ft.com/intl/cms/s/0/82be8d88-5f42-11e2-825000144feab49a.html\#axzz36sNNG1Fr (2014, July 8].

Faucon, B. 2013. Algeria's El Merk Complex Start Oil Production After Security Boost. Rigzone. [Online]. May $\quad 7 . \quad$ Available: http://www.rigzone.com/news/oil_gas/a/126330/Algerias_El_Merk_Complex_Star ts_Oil_Production_After_Security_Boost [2014, August 21].

Faucon, B. Williams, S. Said, S. \& Kent, S. 2013. Energy Firms Seek New Answer to Security Risks. Wall Street Journal. [Online]. 28 January. Available: http://online.wsj.com/news/articles/SB1000142412788732382950457827018105 8676450 [2014, July 1]. 
FBI, 2012. Crime in the United States 2012. [Online]. Available: http://www.fbi.gov/about-us/cjis/ucr/crime-in-the-u.s/2012/crime-in-the-u.s.2012/tables/16tabledatadecpdf [2014, April 15].

Fitzpatrick, M. 1983. The Definition and Assessment of Political Risk in International Business: A Review of the Literature. The Academy of Management. 8(2): 249254.

Fouché, P.J. 2003. A Political-Security Risk Analysis of Uganda. Unpublished.

Four oil workers killed in Algeria bus attack. 2007. Reuters. [Online]. 4 March. Available: http://www.reuters.com/article/2007/03/04/idUSL04254748 [2014, June 5].

Frynas, J. G. 1998. Political Instability and Business: Focus on Shell in Nigeria. Third World Quarterly. 19(3): 457-478.

Frynas, J. G., \& Mellahi, K. 2003. Political risks as firm-specific (dis) advantages: Evidence on transnational oil firms in Nigeria. Thunderbird International Business Review, 45(5): 541-565.

Giroux, J. \& Hilpert, C. 2009. The Relationship Between Energy Infrastructure Attacks and Crude Oil Prices. Journal of Energy Security. [Online]. Available: http://www.ensec.org/index.php?option=com_content\&view=article\&id=216:therelationship-between-energy-infrastructure-attacks-and-crude-oilprices\&catid=100:issuecontent\&Itemid=352 [2014, May 27].

Giroux, J. \& Burgherr, P. 2012. Canvassing the Target of Energy Infrastructure: The Energy Infrastructure Attack Database. Journal of Energy Security. [Online]. Available:

http://www.ensec.org/index.php?option=com_content\&view=article\&id=379: canva ssing-the-targeting-of-energy-infrastructure-the-energy-infrastructure-attackdatabase\&catid=128:issue-content\&Itemid=402 [2014, August, 11]. 
Giroux, J. 2013. Terror Attacks on Energy Infrastructure - A Growing Threat? A roundtable discussion at the Department of War Studies. King's College. Available: http://warstudies.podomatic.com/entry/2013-11-08T04_37_22-08_00 [2014, August 10].

Giroux, J. \& Gilpin, R. 2013. Tackling Energy Infrastructure Vulnerability in ViolenceProne Zones. Journal of Energy Security. [Online]. Available: http://www.fletcherforum.org/2013/02/27/giroux_gilpin/ [2014, May 27].

Gitmark, H. \& Gravklev, B.R. 2013. Statoil I mange risikosoner. Dagsavisen. [Online]. 18 January. Available: http://www.dagsavisen.no/verden/statoil-i-mange-risikoson-er/ [2014, August 19].

Gjelten, T. 2013. Algeria Attack A 'Wake-Up Call' For Energy Companies. NPR. [Online]. 24 January. Available: http://www.npr.org/2013/01/24/170112260/algeria-attack-a-wake-up-call-forenergy-companies [2014, August 21].

Goldstone, J. A. 2011. Cross-class Coalitions and the Making of the Arab Revolts of 2011. Swiss Political Science Review, 17(4): 457-462.

Golob, B. 2013. Cover story: Risk assessment in oil, gas and mining. Communicate. [Online]. Available: http://www.communicatemagazine.co.uk/currentissuemenu/4897-cover-story-riskassessment-in-oil-gas-and-mining [2014, August 21].

Gray, D.H. \& Stockham, E. 20 08. Al-Qaeda in the Islamic Maghreb: the evolution from 
Algerian Islamism to transnational terror. African Journal of Political Science and International Relations. 2(4): 91-97.

Green R.T. \& Smith, C.H. 1972. Multinational Profitability as a Function of Political Instability. Management International Review. 12(6):23-29

Green, S. 2002. Rational Choice Theory: An Overview. Seminar on Rational Choice. Baylor University. [Online]. Available: http://business.baylor.edu/steve_green/green1.doc [2014, March 20].

Gueye, B. 2014. Belmokhtar group issues new threats. Magharebia. [Online]. 1 January. Available: http://magharebia.com/en_GB/articles/awi/features/2014/01/09/feature01 [2014, July 8].

Gupta, D. K. 2008. Understanding Terrorism and Political Violence. The life cycle of birth, growth, transformation, and demise. New York: Routledge

Haendel, D. 1979. Foreign Investements and the Management of Political Risk. Boulder: Westerview.

Hansen, A. \& Vriens, L. 2009. Al-Qaeda in the Islamic Maghreb (AQIM). Council on Foreign Relations. [Online] July 21. Available: http://www. cfr. org/north-africa/alqaeda-islamic-maghreb-aqim/p12717. [2014, May 30].

Harmon, S. 2010. From GSPC to AQIM: The evolution of an Algerian Islamist terrorist group into an Al-Qa'ida Affiliate and its implications for the Sahara-Sahel region. Concerned Africa Scholars, 85: 12-29. 
Held, V. 2004. Terrorism and War. The Journal of Ethics. 8(1): 59-75.

Helman, C. 2013. The World's Biggest Oil Companies, 2013. Forbes. [Online]. 17 November.

Available:

http://www.forbes.com/sites/christopherhelman/2013/11/17/the-worlds-biggest-oilcompanies-2013/ [2014, June 26].

Hirsch, A \& Vidal, J. 2012. Shell spending millions of dollars on security in Nigeria, leaked data shows. The Guardian. [Online]. 19 August. Available: http://www.theguardian.com/business/2012/aug/19/shell-spending-securitynigeria-leak [2014, June 27].

History Bangladesh. 2014. Cairn Energy. [Online]. Available: http://www.cairnenergy.com/index.asp?pageid=18\&history=countries [2014, May 2].

Hough, M. 2008. An Introductory Context of the Methodological, Conceptual, and Theoretical Framework of Risk Analysis, in K.G. Adar, R.O. Iroanya \& F. Nwonwu (eds.). Towards Africa-Oriented Risk Analysis Models. A Contextual and Methodological Approach. Pretoria: Africa Institute of South Africa. 1-17.

Howden, D. 2013. Four days that shook the Sahara: The bloody battle for In Amenas. The Independent. [Online]. 20 January. Available: http://www.independent.co.uk/news/world/africa/four-days-that-shook-the-saharathe-bloody-battle-for-in-amenas-8459243.html [2013. May 28].

Howell, L.D. \& Chaddick, B. 1994. Models of Political Risk for Foreign Investments and Trade. An Assessment of Three Approaches. The Columbia Journal of World 
Business. 29(3): 70-91.

Hunt, E. 2007. Islamist Terrorism in Northwestern Africa. A 'Thorn in the Neck' of the United States? Policy Focus 65.

Jakobsen, J. 2012. Political Risk and the Multinational Company. Concepts, Theories and Evidence. Trondheim: Tapir Akademisk Forlag.

Jegarajah, S. 2013 Experts Had Warned of Attack on In Amenas Gas Plant. CNBC. [Online]. 27 January. Available: http://www.cnbc.com/id/100410586 [2014, July 8].

Jenkins, B.M. 2013. The Motivation Behind the In Amenas Terrorist Attack. RAND Corporation. [Online]. 29 January. Available: http://www.rand.org/blog/2013/01/the-motivations-behind-the-amenas-terroristattack.html [2014, June 9].

Johnston, P. 2008. Oil and Terrorism. Al Qaeda's Threat. [Quebec]: Defence R\&D Canada. Centre for Operational Research and Analysis. [Online]. 20 April. Available: www.academia.edu/471280/Oil_and_Terrorism_Al_Qaedas_Threat [2014, April 8].

Joscelyn, T. \& Roggio, B. 2013. Al Qaeda-linked groups claims credit for kidnappings in Algeria. The Long War Journal. [Online]. 16 January. Available: http://www.longwarjournal.org/archives/2013/01/al_qaeda_commander_c.php?ut

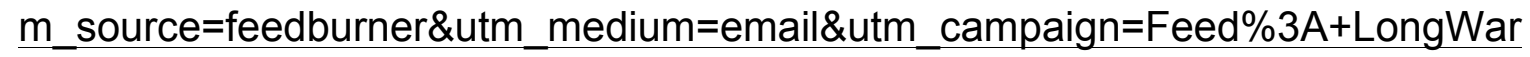
JournalSiteWide+\%28The+Long+War+Journal+\%28Site-Wide\%29\%29 [2014, January 16]. 
Jukov, I. 2012. Norwegian Statoil: Vision and Victory. The OMG. [Online]. 24 August. Available: http://theogm.com/2012/08/24/norwegian-statoil-vision-and-victory/ [2014, August 14].

Kaldor, M. 2012. New and old wars. Organized Violence in a global era. Cambridge: Polity Press.

Kaplan, S \& Garrick, 1981. The Quantitative Definition of Risk. Risk Analysis. 1(1): 1127.

Klare, M.T. 2014. Europe's resource dilemma: Escaping the dependency trap. Europe's World. [Online]. 21 March. Available: http://europesworld.org/2014/03/21/europes-resource-dilemma-escaping-thedependency-trap/\#.U7_h517VtyQ [2014, July 12].

Knott, D. 1997. BP Molds Security Strategy to Fit The Country. Oil \& Gas Journal. [Online]. 6 September. Available: http://www.ogj.com/articles/print/volume95/issue-23/in-this-issue/general-interest/bp-molds-security-strategy-to-fit-thecountry.html [2014, July 1].

Kobrin, S.J. 1979. Political Risk: A Review and Reconsideration. Journal of International Business Studies. 10(1): 67-80.

Kobrin, S.J. 1980. Foreign Enterprise and Forced Divestment in LDCs. International Organization. 34(1): 65-88.

Kobrin, S.J. 1981. Political Assessment by International Firms: Model or Methodologies? Journal of Policy Modeling. 3(2):251-270.

Kobrin, S.J. 1982. Managing political risk assessment. Berkeley, CA: University of 
California Press.

Kobrin, S.J. 1984. Expropriation as an Attempt to Control Foreign Firms in LCDs: trends from 1960 to 1979. International Studies Quarterly. 28(3): 329-348.

KPMG, 2014. No paper chase: Transformation risk management at energy and natural resources companies. [Online]. Available: http://www.kpmg.com/global/en/issuesandinsights/articlespublications/documents Ino-paper-chase.pdf [2014, June 11].

Krauss, C. \& Kulish, N. 2013. Algeria Gas Compound Lacked Armed Guards. The New York Times. [Online]. 23 January. Available: http://www.nytimes.com/2013/01/24/world/africa/algerian-gas-facility-did-nothave-armed-guards.html? r=0 (2014, June 19).

Kulish, N. 2013. Gas Complex Worker Tells of Terror and a Desperate Escape. The New York Times. [Online]. 22 January. Available: http://www.nytimes.com/2013/01/23/world/africa/worker-at-algerian-gas-facilitydescribes-escape.html?pagewanted=1\&mabReward=relbias:w\&module=Search [2014, June 1].

Lambrechts, D. Weldon, C. \& Boshoff, M.J. 2010. Political Insecurity and the Extraction Industry in the Democratic Republic of Congo: Moving towards an Industry Specific Political-security Risk Analysis Mode, in Swart, G. (ed.). A Vanquished Peace? Prospects for the Successful Reconstruction of the Congo. London: Adonis \& Abbey Publishers Ltd.

Langved, Å. 2014. Statoil tilbake på In Amenas. Dagens Næringsliv. [Online]. 23 July. Available: $\quad$ http://www.dn.no/nyheter/utenriks/2014/07/23/2157/Energi/statoiltilbake-pa-in-amenas [2014, July 29].

Lax, H.L. 1983. Political Risk in the International Oil and Gas Industry. Green's Farms: Atlantis, Inc. 
Lebovich, A. 2011. AQIM Returns In Force in Northern Algeria. CTC Sentinel. 4(9): 8-12.

Leone, J. 2010. Post-Sovereign Security and the Absence of the Political. Journal of Peace, Conflict and Development. 16: 87-109.

Lia, B \& Kjøk, A. 2004. Energy Supply as Terrorist Targets? Patterns of Petrolium Terrorism, 1968-99, in Heradstveit, D \& Hveem, H. (eds.). Oil in the Gulf: Obstacles to Democracy and Development. Aldershot: Ashgate.

Lorenz, A. J. 2007. Al Qaeda's Maritime Treat. Intelligence and Terrorism Information Center at the Israel Intelligence Heritage \& Commemoration Center. [Online]. September $19 . \quad$ Available: http://terrorisminformation.com/data/pdf/PDF_19294_2.pdf [2014, March 20].

Luft, G. \& Korin, A. 2003. Terror's next target. The Journal of international Security Affairs. 6: 95-101.

Macfarquhar, N. 2004. Five Foreigners Killed in Attack At Saudi Office. The New York Times. May 2. Available: http://www.nytimes.com/2004/05/02/world/fiveforeigners-killed-in-attack-at-saudi-office.html [2014, May 17].

March, J.G. \& Shapira, Z. 1987. Managerial Perspectives on Risk and Risk taking. Management Science. 33(11): 1404-1418.

Marret, J.L. 2008. Al-Qaeda in Islamic Maghreb: A "Glocal" Organization. Studies in Conflict \& Terrorism. 31: 541-552.

Marshall, P. 2002. The Next Hotbed Of Islamic Radicalism. The Washington Post. [Online]. 8 October. Available: http://www.freedomhouse.org/article/next-hotbedislamic-radicalism\#.U4MydV7VtyQ [2014, May 26]

Martinez, L. 2000. The Algerian Civil War. 1990-1998. London: C. Hurst \& Co. 
Martinez, L. 2006. Why the violence in Algeria? The Journal of North African Studies. 9(2): 14-27.

Mathur, K.M. 1996. Crime, Human Rights and National Security. New Delhi: Gyan Publishing House.

Mclvor, T. 2013. Baron Oil affected by terrorist attacks in Colombia. London South East. [Online]. 27 January. Available: http://www.Ise.co.uk/AllNews.asp?code=3ebsy8sr\&headline=Baron_Oil_Operatio ns_Affected_By_Terrorist_Attacks_In_Colombia [2014, April 8].

Miller, K.D. 1992. A Framework for Integrated Risk Management in International Business. Journal of International Business Studies. 23(2):311-331.

Mingqi, L. 2012. The Global Economy is Now More Vulnerable to Oil Prices than Ever. Oilprices.com. [Online]. 14 March. Available: http://oilprice.com/Energy/Oil-Prices/TheGlobal-Economy-is-Now-More-Vulnerable-to-Oil-Prices-than-Ever.html [2014, July 12].

Minor, M.S. 1994. The Demise of Expropriation as an instrument of LDC Policy, 19801992. Journal of International Business Studies, 25(1)177-188.

Molinski, D. 2013. Rebels in Colombia hit energy sector hard in 'Black October'. The Wall Street Journal. [Online]. 2 November. Available: http://online.wsj.com/news/articles/SB1000142405270230407320457917355054 9400052 [2014, April 26].

Moran, T.H. 1998. Lessons in the management of international political risk from the natural resource and private infrastructure sectors, in Moran, T.H. (ed.). Managing international political risk. Malden, MA: Blackwell. 
Naji, A. B. 2004. The Management of Savagery: The Most Critical Stage Through Which the Umma Will Pass. [English Translation] Olin Institute for Strategic Studies. Harvard University

National Consortium for the Study of Terrorism and Responses to Terrorism, 2013. Annex of Statistical Information: Country Reports on Terrorism 2012. Maryland: University of Maryland. [Online]. Available: http://www.state.gov/documents/organization/210288.pdf [2014, April 28].

National Consortium for the Study of Terrorism and Responses to Terrorism. 2013. Global Terrorism Database. [Online]. Available: http://www.start.umd.edu/gtd/ [2014, June 20].

Neuman, W.L. 2011. Social Research Methods, Qualitative and Quantitative Aapproaches. Boston: Pearson Education

Nossiter, A. \& Kulish, N. 2013. Militants' Goal in Algeria Gas Plant Siege: Giant Fireball. The New York Times. [Online]. 2 February. Available: http://www.nytimes.com/2013/02/03/world/africa/hostage-accounts-detail-eventsat-saharan-gas-

plant.html?pagewanted=1\&mabReward=relbias:w\&_r=0\&module=Search $[2014$, June 2].

Oxy Drops Petroecuador Suit, Focuses on Government Case. 2006. Rigzone. [Online] 5 October. Available: http://www.rigzone.com/news/oil_gas/a/36834/Oxy_Drops_Petroecuador_Suit_F ocuses_on_Government_Case [2014, April 29].

Pham, J. P. 2008. Al-Qaeda in the Islamic Maghreb: An Evolving Challenge in the War 
on Terror. World Defense Review. 8.

Pippard, T. 2010. 'Oil-Qaeda': Jihadist Threats to the Energy Sector. Perspectives on Terrorism, 4(3): 3-14.

Plumer, B. 2014. How the oil boom could change U.S. foreign policy. The Washington Post. [Online]. 16 January. Available: http://www.washingtonpost.com/blogs/wonkblog/wp/2014/01/16/how-the-u-s-oilboom-is-changing-the-world-in-6-charts/ [2014, July 11].

Poynter, T.A. 1982. Government Intervention in Less Developed Countries: The Experience of Multinational Companies. Journal of International Business Studies. 13(1): 9-25.

Price WaterHouse Coopers. 2010. Convergence of security risks: Addressing the security dilemma in today's age of blended threats. [Online]. Available: http://www.asis.org.uk/documents/Security\%20Risk\%20Convergence_FINAL\%20 v2.pdf [2014, August 14].

Pringle, C. \& Lambrechts, D. The Risk of Humanitarianism: Towards an Inclusive Model. Strategic Review for Southern Africa, 33(2):51-80.

Profile: Mokhtar Belmokhtar. 2013. BBC. [Online]. 4 June. Available: http://www.bbc.com/news/world-africa-21061480 [2014, June 5]. 
Ree, M. 2013 Statoil I Algeria. Slik fungerer Statoils In Amenas anlegg. Teknisk Ukeblad. [Online]. 17 January. Available: http://www.tu.no/petroleum/2013/01/17/slik-fungerer-statoils-in-amenas-anlegg [2014, May 22].

Reinhart, C. \& Rogoff, K, 2002. FDI to Africa: The role of price stability and currency instability. International Monetary Fund, Working Paper 03/10.

Robock, S.H. 1971. Political Risk: Identification and Assessment. Columbia Journal of World Business. 4: 6-20.

Robock, S.H. \& Simmonds, K. 1989. International business and multinational enterprises (4th ed.). Homewood, IL: Irwin.

Roggio, B. 2013. Belmokhtar claims Algeria raid, slaying of hostages for al Qaeda. The Long War Journal. [Online]. 20 January. Available: http://www.longwarjournal.org/archives/2013/01/belmokhtar_claims_al.php\# [2014, June 9].

Royal Dutch Shell. 2014. Annual Report 2013. London: Royal Dutch Shell.

Ruby, C.L. 2002. The Definition of Terrorism. Analysis of Social Issues and Public Policy. 2(1): 9-14.

Russell, C.A., Banker, L.J. \& Miller, B.H. 1979. Out-Inventing the Terrorist, in Alexander, 
Y., Carlton, D. \& Wilkinson, P. (eds.). Terrorism: Theory and Practice. Boulder: Westview Press, Inc.

Ryggvik, H. 2014. Statoil Asa. Store Norske Leksikon. [Online] Available: http://snl.no/Statoil_ASA [2014, May 21]

SC/11004. 2013. Security Council $6965^{\text {th }}$ meeting. [Online]. 13 May. Available: http://www.un.org/News/Press/docs/2013/sc11004.doc.htm [2014, May 28].

Schmid, A.P. \& Jongman, A.J. 1988. Political Terrorism. Amsterdam: North Holland Publishing Company.

Security Service, MI5. Undated. [Online]. Available: https://www.mi5.gov.uk/home/thethreats/terrorism.html [2014, March 4].

Shahin, E.E. 1997. Political Ascent: Contemporary Islamic Movements in North Africa. Boulder: Westview Press.

Sedarat, F. 2007. Al Qaeda claim bomb in Algeria. Reuters. [Online]. Available: http://uk.reuters.com/article/2007/09/21/uk-algeria-bombidUKL2114649420070921 [2014, May, 20].

Senussi, M. \& Ziemba, R. 2010. Maghreb: 2011 Outlook. Roubini Global Economics. [Online] 7 December. Available: http://www.roubini.com/analysis/140746.php |2014, June 9].

Shahin, E. E. 1997. Political Ascent: Contemporary Islamic Movements in North Africa. Boulder: Westview Press. 
Simon, H.A. 1955. Behavioral Model of Rational Choice. The Quarterly Journal of Economics. 69(1): 99-118.

Simon, H.A. 1979. Rational Decision Making in Business Organizations. The American Economic Review. 69(4): 493-513.

Simon, H.A. 1982. Political Risk Assessment: Past Trends and Future Prospects. Columbia Journal of World Business. 17(3):62-70.

Simon, H.A., Dantzig, G.B., Hogarth, R., Plott, C.R., Raiffa, H., Schelling, T.C. Shepsle, K.A., Thaler, R., Tversky, A., \& Winter, S. 1987. Decision-making and problemsolving. Interfaces, 17(5):11-31.

Statoil, 2013a. The In Amenas Attack. Report of the investigation into the terrorist attack on In Amenas. Prepared for Statoil ASA's board of directors. [Online]. Available: http://www.statoil.com/en/NewsAndMedia/News/2013/Pages/12Sep_InAmenas_r eport.aspx [2014, February 3].

Statoil.

2013b.

Aktiviteter.

[Online].

Available:

http://www.statoil.com/no/About/Worldwide/Algeria/Activities/Pages/default.aspx [2014, April 29].

Statoil, 2013c. Annual Report 2012. Stavanger: Statoil.

Statoil, 2014. Annual Report 2013. Stavanger: Statoil.

Steinberg, G. \& Werenfels, I. 2007. Between the 'Near'and the 'Far'. Enemy: Al-Qaeda in the Islamic Maghreb. Mediterranean Politics. 12(3): 407-413. 
Steinhäusler, F., Furthner, P., Heidegger, W., Rydell, S. \& Zaitseva, L. 2008. Security Risk to the Oil and Gas Industry: Terrorist Capabilities. Strategic Insight. (8)1:144.

Stoltenberg og Cameron sammen mot terror, 2013. Dagbladet. [Online]. 25 January Available:

http://www.dagbladet.no/2013/01/25/nyheter/politikk/utenriks/storbritannia/norge/ 25434845/ [2014, September 13].

Stora, B. 2004. Algeria 1830-2000. A Short History. Translated by J.M. Todd. London: Cornell University Press.

Sutton, J. 2012. USS Cole bomb suspect finally gets his day in court. Reuters. [Online]. 8 November. Available: http://www.reuters.com/article/2011/11/08/us-usaguantanamo-usscole-idUSTRE7A730120111108 |2014, April 24].

Tadjbakhsh, S. 2005. Human Security: Concepts and Implications with an Application to Post-Intervention Challenges in Afghanistan. [Online]. Available: www.sciencespo.fr/ceri/sites/sciencespo.fr.ceri/files/etude117_118.pdf $\quad[2014$, April 10].

Taheri, A. 2008. Al-Qaeda's sinister creep into North Africa. The Times. [Online]. 30 July. Available: http://www.timesonline.co.uk/tol/comment/columnists/guest_contributors/article44 25820.ece. [2014, May 30].

Terrapinn, C. 2013. How the Algerian Terrorist Attack is Affecting the Oil and Gas Industry. The Oil \& Gas Post. [Online]. 1 March. Available: http://www.oilgaspost.com/2013/03/01/algerian-terrorist-attack-affecting-oil-gasindustryl [2014, August 12]. 
The In Amenas attack - one year after. 2014. Norwegian Institute of International Affaires. [Online]. Available: http://english.nupi.no/Activities/News/The-InAmenas-attack-One-year-after [2014, August 18].

The Statoil Book. 2013. Statoil. 5 July. [Online] Available: http://www.statoil.com/en/about/thestatoilbook/downloads/theststaoilbook.pdf [2014, July 4].

Thomas, J. 2013. The In Amenas Gas facility Attack: A New Mindset Required for Corporate Sector. Future Directions International. [Online]. Available: http://www.futuredirections.org.au/publications/associate-papers/1434-the-inamenas-gas-facility-attack-a-new-mindset-required-for-corporate-sector.html [2014, June 20].

Thornton, T.P. 1964. Terror as a Weapon of Political Agitation, in Eckstein, H. (ed.). Internal War. New York: The free press of Glencoe.

Tjelta, S.A. 2004 Statoil åpner kontor i Algerie. Offshore.no. [Online]. 27 September. Available: http://www.offshore.no/sak/8779_statoil_aapner_kontor_i_algerie [2014, July 4).

Toft, P., Duero, A. \& Bieliauskas, A. 2010. Terrorist targeting and energy security. Energy Policy. 38: 4411-4421.

Trindal, J. 2013. Gas Refinery Attack in Algeria: The Lessons Learned. Domestic $\begin{array}{llll}\text { Preparedness. } & \text { [Online]. } & 20 & \text { March. }\end{array}$ http://www.domesticpreparedness.com/Infrastructure/Building_Protection/Gas_R efinery_Attack_in_Algeria:_The_Lessons_Learned/ [2014, July 10].

Tversky, A. \& Kahneman, D. 1986. Rational Choice and the Framing of Decisions. The Journal of Business, 59(4): 251-278.

Unpacking Algeria's hostage crisis. 2013. Al Jazeera. [Online]. 21 January. Available: 
http://www.aljazeera.com/programmes/insidestory/2013/01/20131201324107553 99.html [2014, June 1].

U.S Department of State, 2012. Title 22, Section 2656f(a). United States Code.

Uzodike, U.O. \& Isike, C. 2009. Whose security? Understanding the Niger Delta crisis as a clash of two security conceptions. African Security Review. 18(3): 103-116.

Venter, A. 1998. An assessment of micro-political risks: reasoned decision making as a management tool. Politeia. 17(2): 3-28.

Weinberg, D.M., Coplon, G.H. \& Williams, J. 2008. Oil Industry has a new risk factor: terrorism. Oil and Gas Journal. [Online]. 3 March. Available: http://www.ogj.com/articles/print/volume-106/issue-9/general-interest/oil-industryhas-new-risk-factor-terrorism.html [2014, August 14].

Wells, L.T. 1998. God and Fair Competition: Does the Foreign Direct Investor Face Still Other Risks in Emerging Markets? In T.H. Moran (ed.). Managing International Political Risk. Malden: Blackwell Publishers Ltd. 15-43.

Whittaker, D.J. (ed.). 2007. The Terrorism Reader. New York: Routledge.

Williams, S \& Amiel, G. 2013. Foreign Firms in Algeria Boost Security. The Wall Steet Journal. [Online]. 17 January. Available: http://online.wsj.com/news/articles/SB1000142412788732446810457824785069419083 
$\underline{8}[2014$, July 1$]$.

Yetiv, S. 2011. The Petroleum Triangle: Oil, Globalization, and Terror. New York: Cornell University Press.

Zarroli, J. 2013. Algeria Attack Raises Security Alarms for Energy Firms. NPR. [Online]. 22 January. Available: http://www.npr.org/2013/01/22/170000601/algeria-attackraises-security-alarms-for-energy-firms

Zhdannikov, D. \& Johnson, C. 2014. U.S. Oil Boom Seen Further Eroding OPEC Market Share. Daily Finance. [Online]. 11 July. Available: http://www.dailyfinance.com/2014/07/11/us-oil-boom-erode-opec-share/ [2014, July 11]. 


\section{Appendix A}

Attacks against the oil and gas industry in the Maghreb region: 2001-2011

\begin{tabular}{|c|c|c|c|}
\hline Date & Country & City & Perpetrator \\
\hline $2001-11-30$ & Algeria & Krakrib & GSPC \\
\hline 2002-01-19 & Algeria & Krakrib & GSPC \\
\hline 2002-05-17 & Algeria & Krakrib & GSPC \\
\hline 2004-06-21 & Algeria & Algiers & GSPC \\
\hline 2005-03-09 & Algeria & Ammal & Unknown \\
\hline 2005-09-15 & Algeria & Trig El Qares & GSPC \\
\hline $2006-02-23$ & Algeria & Zemmouri & GSPC \\
\hline 2006-08-13 & Algeria & Krakrib & Unknown \\
\hline $2007-02-20$ & Algeria & Oued Slama & AQIM \\
\hline $2007-04-11$ & Algeria & Ain Sebih & $\begin{array}{c}\text { Algerian Islamic } \\
\text { Extremists }\end{array}$ \\
\hline 2007-04-11 & Algeria & Skikda & Unknown \\
\hline 2007-05-15 & Algeria & Jijel & AQIM \\
\hline $2007-06-22$ & Algeria & Draa El-Mizan & AQIM \\
\hline $2007-07-20$ & Algeria & Souk El Had & AQIM \\
\hline 2007-09-12 & Algeria & Si Mustapha & AQIM \\
\hline 2007-11-04 & Algeria & Skikda & Unknown \\
\hline 2007-12-08 & Algeria & Algiers & Unknown \\
\hline 2008-03-03 & Algeria & Laadjadra & AQIM \\
\hline $2008-07-17$ & Algeria & Aomar & AQIM \\
\hline 2009-02-22 & Algeria & Ziama Mansouria & AQIM \\
\hline 2009-04-19 & Algeria & Bir El Ater & Unknown \\
\hline 2009-06-08 & Algeria & Jijel & Unknown \\
\hline $2009-11-23$ & Algeria & Thenia & AQIM \\
\hline $2010-07-31$ & Algeria & El Oglat Krakra & AQIM \\
\hline 2010-08-01 & Algeria & Bir El Ater & AQIM \\
\hline 2011-07-19 & Tunisia & Zaghouan & Unknown \\
\hline 2011-09-12 & Libya & Ras Lanuf & Unknown \\
\hline 2011-11-17 & Algeria & Djabahia & AQIM \\
\hline $2011-12-06$ & Algeria & Aomar & AQIM \\
\hline
\end{tabular}

(Source: Adapted from, National Consortium for the Study of Terrorism and Responses to Terrorism, 2013; Center for Security Studies, 2012) 


\section{Appendix B}

Terror attacks against the oil and gas industry in Africa, Latin America and Middle East:

$$
2001-2011^{8}
$$

\begin{tabular}{|c|c|c|c|}
\hline Date & Country & Fatalities & Casualties \\
\hline $2001-10-21$ & Colombia & 4 & 11 \\
\hline $2002-05-07$ & Colombia & 2 & 4 \\
\hline 2002-10-06 & Yemen & 1 & 12 \\
\hline $2002-12-22$ & Colombia & 2 & 11 \\
\hline $2003-08-10$ & Colombia & 0 & 20 \\
\hline 2003-12-01 & Turkey & 5 & 4 \\
\hline $2004-06-21$ & Algeria & 0 & 11 \\
\hline $2005-10-15$ & Turkey & 0 & 5 \\
\hline $2006-02-24$ & Saudi Arabia & 4 & 4 \\
\hline $2006-05-22$ & Colombia & 5 & 9 \\
\hline $2006-10-04$ & Colombia & 1 & 4 \\
\hline $2007-04-20$ & Nigeria & 0 & 6 \\
\hline $2007-10-31$ & Nigeria & 1 & 4 \\
\hline $2007-11-08$ & Yemen & 12 & 6 \\
\hline $2006-11-30$ & Nigeria & 3 & 6 \\
\hline $2008-03-04$ & Algeria & 1 & 7 \\
\hline $2008-04-14$ & Ethiopia & 3 & 18 \\
\hline $2008-09-15$ & Nigeria & 1 & 4 \\
\hline $2009-06-30$ & Colombia & 1 & 4 \\
\hline $2010-04-27$ & Algeria & 0 & 6 \\
\hline $2010-07-11$ & Colombia & 10 & 4 \\
\hline $2011-04-10$ & Colombia & 0 & 4 \\
\hline
\end{tabular}

(Source: Adapted from, National Consortium for the Study of Terrorism and Responses to Terrorism, 2013).

\footnotetext{
8 This is a summary of terror attacks against the oil and gas industry with the most impact with reference to fatalities and casualties.
} 